\title{
Controls on Atmospheric Exchanges of Carbon Dioxide and Methane for a Variety of Arctic Tundra Types
}

\author{
by \\ Shari Louise Hayne \\ B.Sc. Hon, St. Francis Xavier University, Antigonish, Nova Scotia Canada, 2004
}

\begin{abstract}
A thesis Submitted to the
Faculty of Graduate Studies and Research

in partial fulfilment of the requirements for the degree of

Master of Science

Department of Geography and Environmental Studies

Carleton University

Ottawa, Ontario, Canada

December 2009
\end{abstract}

(C) 2009, S. L. Hayne 
Library and Archives Canada

Published Heritage Branch

395 Wellington Street Ottawa ON K1A ON4 Canada
Bibliothèque et

Archives Canada

Direction du

Patrimoine de l'édition

395 , rue Wellington Ottawa ON K1A 0N4

Canada
Your file Votre reférence

ISBN: 978-0-494-64433-1

Our file Notre référence

ISBN: 978-0-494-64433-1
NOTICE:

The author has granted a nonexclusive license allowing Library and Archives Canada to reproduce, publish, archive, preserve, conserve, communicate to the public by telecommunication or on the Internet, loan, distribute and sell theses worldwide, for commercial or noncommercial purposes, in microform, paper, electronic and/or any other formats.

The author retains copyright ownership and moral rights in this thesis. Neither the thesis nor substantial extracts from it may be printed or otherwise reproduced without the author's permission.
AVIS:

L'auteur a accordé une licence non exclusive permettant à la Bibliothèque et Archives Canada de reproduire, publier, archiver, sauvegarder, conserver, transmettre au public par télécommunication ou par l'Internet, prêter, distribuer et vendre des thèses partout dans le monde, à des fins commerciales ou autres, sur support microforme, papier, électronique et/ou autres formats.

L'auteur conserve la propriété du droit d'auteur et des droits moraux qui protège cette thèse. $\mathrm{Ni}$ la thèse ni des extraits substantiels de celle-ci ne doivent être imprimés ou autrement reproduits sans son autorisation.
In compliance with the Canadian Privacy Act some supporting forms may have been removed from this thesis.

While these forms may be included in the document page count, their removal does not represent any loss of content from the thesis.
Conformément à la loi canadienne sur la protection de la vie privée, quelques formulaires secondaires ont été enlevés de cette thèse.

Bien que ces formulaires aient inclus dans la pagination, il n'y aura aucun contenu manquant. 


\begin{abstract}
This study examined fluxes and subsurface concentrations of carbon dioxide $\left(\mathrm{CO}_{2}\right)$ and methane $\left(\mathrm{CH}_{4}\right)$ for six different vegetation community plots during the 2008 growing season at Daring Lake, N.W.T. The objectives of this study were: 1) to assess the temporal and spatial variability of $\mathrm{CO}_{2}$ and $\mathrm{CH}_{4}$ flux within different arctic tundra ecosystems; and 2) to quantify and understand the mechanisms that control $\mathrm{CO}_{2}$ and $\mathrm{CH}_{4}$ flux. Hydrology was an important driver of $\mathrm{CO}_{2}$ and $\mathrm{CH}_{4}$ exchange among vegetation communities. High spatial variability in $\mathrm{CH}_{4}$ exchange in wet sites was found due to the position of the water relative to microtopography. Major differences were found between subsurface gas dynamics in mineral and peat soils. Sedge and fen tussock and hollow sites displayed much higher heterogeneity among profiles than the heath and shrub sites. Controls on subsurface production, oxidation and transport contributed to the surfaceatmosphere flux of $\mathrm{CO}_{2}$ and $\mathrm{CH}_{4}$.
\end{abstract}




\section{ACKNOWEDGEMENTS}

Many thanks go to my supervisor Dr. Elyn Humphreys, for her exceptional guidance, support, field assistance and for providing the wonderful opportunity to carry out research in the Canadian arctic. I am also grateful for the enthusiasm and hard work of field and lab assistants Kaitlin Wilson and Nancy Grenier with whom I shared buggy conditions, cold swims and beautiful arctic landscapes. Thank you also to Michael Treberg for building custom equipment and Samantha Piquette and Johnny Vanderwint for assistance in biomass collection and processing. Dr. Edward Gregorich and his laboratory team at the Agriculture and Agrifood Canada laboratory provided expertise on methodology for gas sample storage and laboratory analysis. Thanks also go to Dr. Mike Pisaric for the use of his muffle furnace and to Carleton Geography lab technicians Dave Bertram and Quang Ngo for their assistance with lab and field equipment. Dr. KlausHolger Knorr provided expertise for the equipment design and analysis required for Chapter 3. Steve Matthews, Department of Wildlife and Environment, Government of N.W.T gave logistical support at the Tundra Ecological Research Station, Daring Lake, N.W.T.

Funding for this research was provided by the Natural Sciences and Engineering Research Council of Canada (NSERC), the W. Garfield Weston Foundation, Indian \& Northern Affairs Canada (Northern Scientific Training Program) and the International Polar Year - Climate Impacts on Canadian Arctic Tundra project.

Special thanks to my loving partner Nancy, who was always very supportive of my research and my son Zackary, who gave me many smiles during thesis writing breaks. 


\section{TABLE OF CONTENTS}

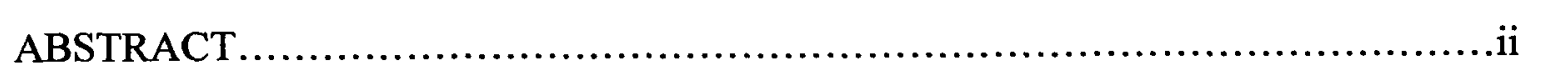

ACKNOWEDGEMENTS..........................................................

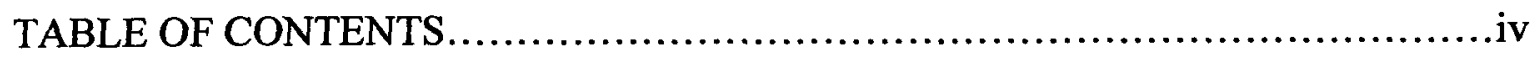

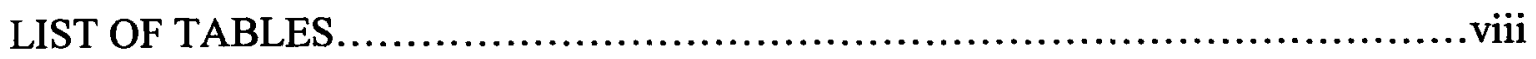

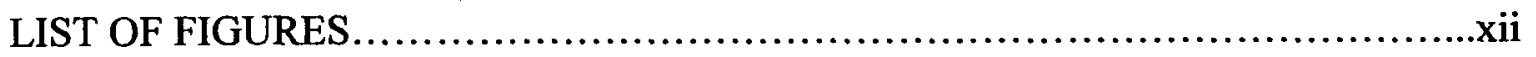

LIST OF SYMBOLS AND ABBREVIATIONS ..................................xvi

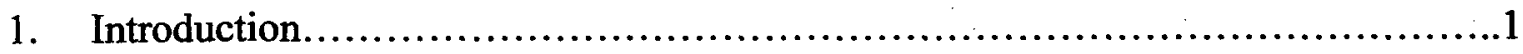

2. Fluxes of Carbon Dioxide and Methane from a Variety of Tundra Vegetation Communities in the Southern Canadian Arctic.....................................14

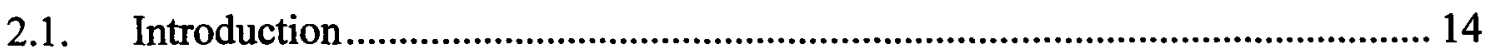

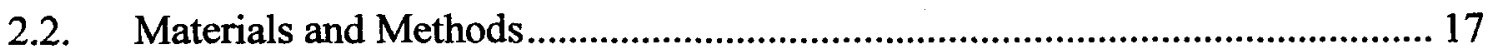

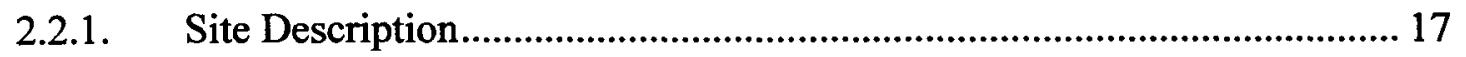

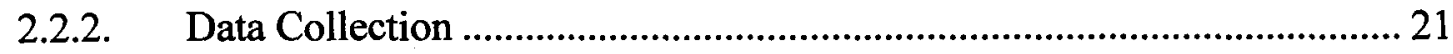

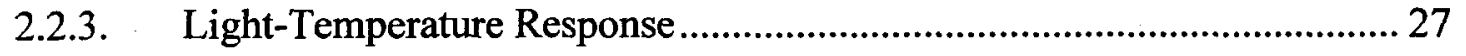

2.2.4. Modeling the Carbon Balance and Radiative Forcing Potential of Each

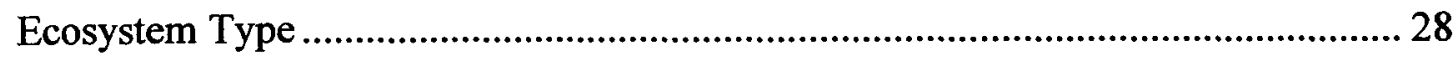
iv 
2.2.5. Statistical Analysis

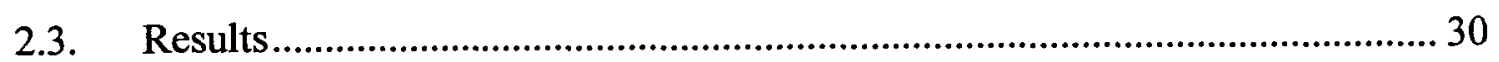

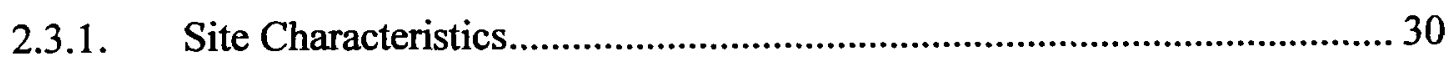

2.3.2. Net Ecosystem Exchange of $\mathrm{CO}_{2}$ (NEE) ................................................ 38

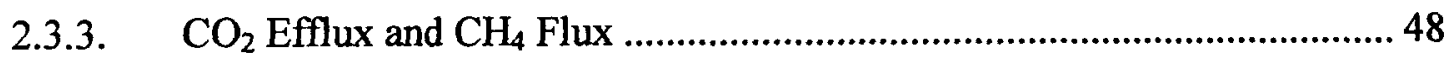

2.3.4. Examining the Variations in Carbon Fluxes Within Vegetation

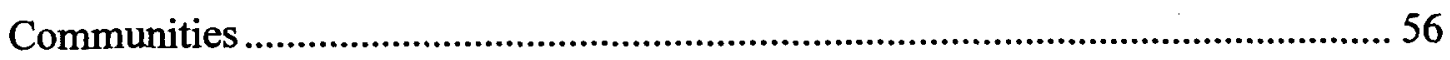

2.3.5. Examining the Variations in Carbon Fluxes Among Vegetation

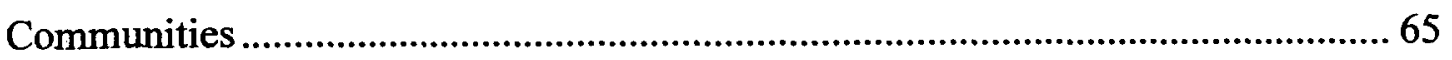

2.3.6. Modeled Carbon Balance and Global Warming Potential.......................... 67

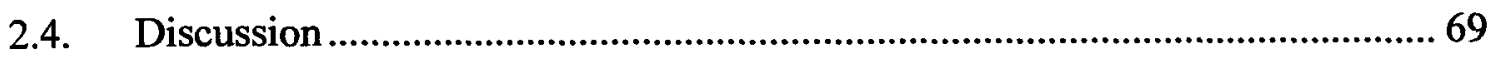

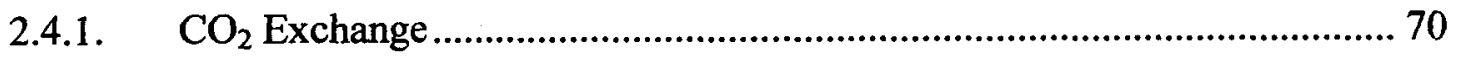

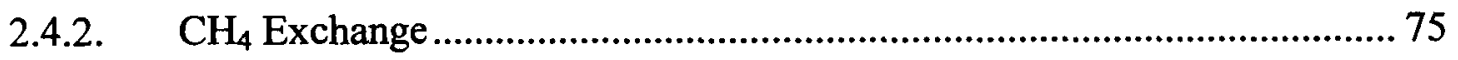

2.4.3. Temporal Variations in Carbon Exchange ................................................. 77

2.4.4. Growing Season Carbon Balance \& Global Warming Potential ............... 78

2.4.5. Potential Effects of Climate Change ........................................................ 80

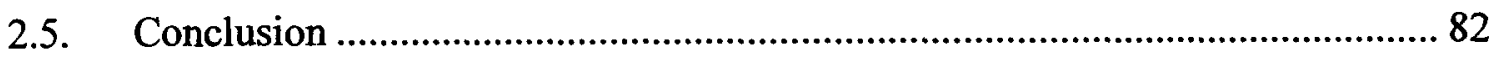


3. Subsurface Concentrations of Carbon Dioxide and Methane from Vegetation Community Plots in the Southern Canadian Arctic....................................83

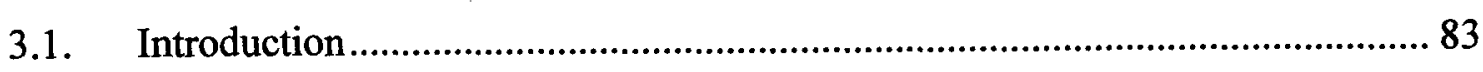

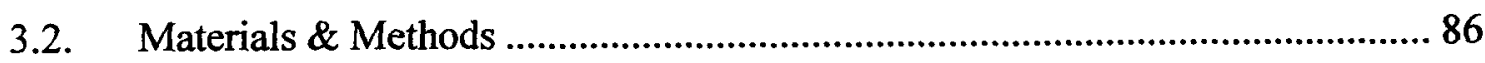

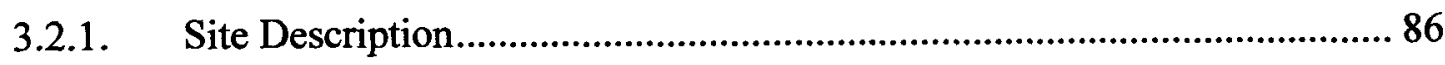

3.2.2. Subsurface Gas Samplers....................................................................... 87

3.2.3. Surface Flux Measurements................................................................. 92

3.2.4. Environmental Measurements ............................................................... 92

3.2.5. $\mathrm{CO}_{2}$ and $\mathrm{CH}_{4}$ Concentration Calculations ............................................. 94

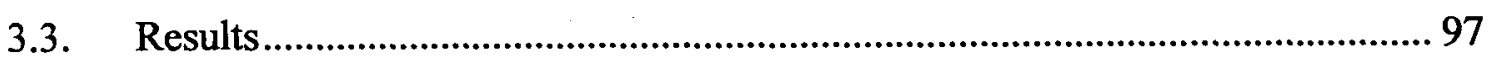

3.3.1. Site Characteristics.............................................................................. 97

3.3.2. Subsurface $\mathrm{CO}_{2}$ and $\mathrm{CH}_{4}$ Concentrations ............................................ 103

3.3.3. The Influence of Environmental Conditions on $\mathrm{CO}_{2}$ and $\mathrm{CH}_{4}$ Concentrations ................................................................................................... 113

3.3.4. Ebullition Events................................................................................ 122

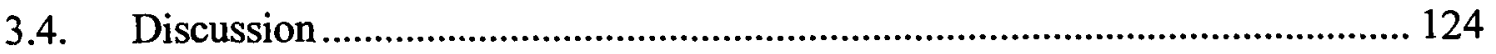

3.4.1. Heath \& Shrub Sites......................................................................... 124 
3.4.2. Sedge \& Fen Tussock Sites.................................................................. 127

3.4.3. Sedge \& Fen Hollow Sites ................................................................... 130

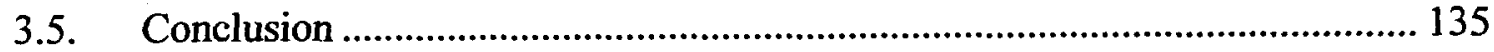

4. Summary \& Conclusion........................................................

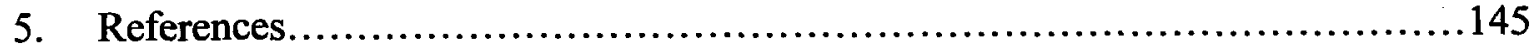

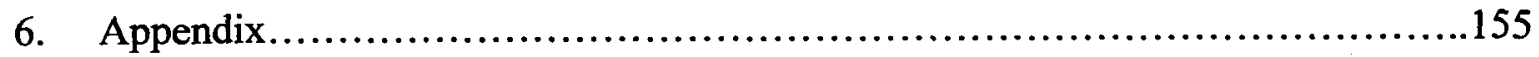




\section{LIST OF TABLES}

Table 2.1: Soil and vegetation characteristics of the six tundra environments at Daring Lake, N.W.T during July and August, 2008. Values in brackets indicate \pm 1 standard error of the mean. Texture and organic matter content were not assessed separately for tussocks and hollows. Values for each variable that do not share superscript letters in common indicate significant differences between ecosystems (Tukey's HSD, $p<0.05$ ).. 31 Table 2.2: Environmental characteristics of the six tundra environments at Daring Lake, N.W.T. Values are mean of the 4 collar locations during July and August 2008 (values in brackets indicate \pm 1 standard error of the mean). Values for each variable that do not share superscript letters in common indicate significant differences between ecosystems (Tukey's HSD, $\mathrm{p}<0.05$ ). VWC, volumetric water content. 32

Table 2.3: Field measurements of NEE exchange and component fluxes for the six vegetation communities Values are mean \pm 1 standard error of the mean. NEE, net ecosystem exchange of $\mathrm{CO}_{2}$; NEEmax, average NEE for PAR greater than $1000 \mu \mathrm{mol} \mathrm{m}{ }^{-}$ ${ }^{2} \mathrm{~s}^{-1}$; ER, ecosystem respiration of $\mathrm{CO}_{2}$; GEPmax, gross ecosystem production for PAR greater than $1000 \mu \mathrm{mol} \mathrm{m} \mathrm{m}^{-2} \mathrm{~s}^{-1}$. Negative values indicate carbon uptake and positive values indicate carbon loss by the ecosystem. Values for each variable that do not share superscript letters in common indicate significant differences between communities (Tukey's HSD, $\mathrm{p}<0.05$ ) 40

Table 2.4: Parameters for Equation 2.2 describing the response of NEE to PAR and chamber air temperature for the six vegetation communities (values in brackets indicate \pm 1 standard error). NEE, net ecosystem exchange of $\mathrm{CO}_{2} ; \mathrm{PAR}$, photosynthetically active 
radiation; GPmax, maximum gross photosynthesis; $\alpha$, initial slope of the curve; $R_{10}$, ecosystem respiration at a reference temperature of $10^{\circ} \mathrm{C} ; \mathrm{n}$, number of observations; $\mathrm{r}^{2}$, coefficient of determination. Negative values indicate carbon uptake and positive values indicate carbon loss by the ecosystem. Values for each variable that do not share superscript letters in common indicate significant differences between ecosystems (where the $95 \%$ confidence limits did not overlap).

Table 2.5: Parameters for Equation 2.2 describing the response of NEE to PAR and T for shrub site collars grouped by similar vegetation community characteristics (values in brackets indicate \pm 1 standard error of the mean). Symbols are described in Table 2.4. Negative values indicate carbon uptake and positive values indicate carbon loss by the ecosystem 46

Table 2.6: The range and mean (values in brackets indicate \pm 1 standard error of the mean) $\mathrm{CO}_{2}$ flux measured with the opaque static chambers for the six vegetation communities.

Table 2.7: The range and mean (values in brackets indicate \pm 1 standard error of the mean) $\mathrm{CH}_{4}$ flux measured with the opaque static chambers for the six vegetation communities.

Table 2.8: Spearman's rho correlation coefficients showing significant relationships between environmental variables and $\mathrm{CO}_{2}$ effluxes, p-values are given in brackets. 58 Table 2.9: Spearman's correlation coefficients showing significant relationships between environmental variables and $\mathrm{CH}_{4}$ fluxes, $\mathrm{p}$-values are given in brackets. 
Table 2.10: Spearman's correlation coefficients showing significant relationships between NEE and its component fluxes GEP and ER, p-values are given in brackets. ... 63 Table 2.11: Spearman's correlation coefficients showing significant relationships between $\mathrm{CO}_{2}$ efflux and $\mathrm{CH}_{4}$ flux and NEE and its component fluxes GEP and ER, pvalues are given in brackets. 64

Table 2.12: Modeled carbon balance and global warming potential (GWP) for each site for July and August 2008. Positive numbers indicate carbon loss to the atmosphere and negative numbers indicate carbon gain. 68 Table 3.1: Soil characteristics of the six vegetation communities at Daring Lake, N.W.T. Values in brackets indicate \pm 1 standard error of the mean. Texture and organic matter content were not assessed separately for tussocks and hollows. The depth of organic matter at the sedge and fen tussocks is an estimate given the depth at the hollows plus an average 10 and $20 \mathrm{~cm}$ height of tussocks respectively. 98 Table 3.2: Spearman's correlation coefficients showing significant relationships between environmental variables and subsurface $\mathrm{CO}_{2}$ and $\mathrm{CH}_{4}$ concentrations at the heath site, $\mathrm{p}$ values are given in brackets 115

Table 3.3: Spearman's correlation coefficients showing significant relationships between environmental variables and subsurface $\mathrm{CO}_{2}$ and $\mathrm{CH}_{4}$ concentrations at the shrub site, $\mathrm{p}$ values are given in brackets. 116

Table 3.4: Spearman's correlation coefficients showing significant relationships between environmental variables and subsurface $\mathrm{CO}_{2}$ and $\mathrm{CH}_{4}$ concentrations at the sedge and fen tussock sites $\mathrm{p}$-values are given in brackets. 
Table 3.5: Spearman's correlation coefficients showing significant relationships between environmental variables and subsurface $\mathrm{CO}_{2}$ and $\mathrm{CH}_{4}$ concentrations at the sedge hollow

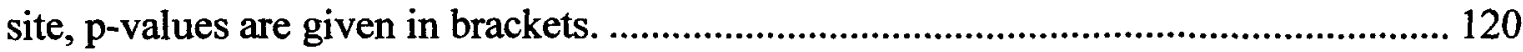
Table 3.6: Spearman's correlation coefficients showing significant relationships between environmental variables and subsurface $\mathrm{CO}_{2}$ and $\mathrm{CH}_{4}$ concentrations at the fen hollow site, $\mathrm{p}$-values are given in brackets. 121 


\section{LIST OF FIGURES}

Figure 1.1: Location of the Daring Lake research site in the Northwest Territories. ....... 11 Figure 2.1: Map of the research valley at Daring Lake, N.W.T with site locations (http://atlas.nrcan.gc.ca). 18

Figure 2.2: Vegetation community plots left to right: heath, sedge (tussock \& hollow), shrub and fen (tussock \& hollow). 20

Figure 2.3: Total daily precipitation $(\mathrm{mm})$, total daily photosynthetically active radiation (PAR) (mol m-2), average daily temperature $\left({ }^{\circ} \mathrm{C}\right)$ at $1.5 \mathrm{~m}$ from ground, and average daily atmospheric pressure $(\mathrm{kPa})$ at Daring Lake, N.W.T from July $1^{\text {st }}$ to August $31^{\text {st }}$, 2008. 35

Figure 2.4: Soil volumetric water content from $0-20 \mathrm{~cm}$ depth $\left(\mathrm{m}^{3} \mathrm{~m}^{-3}\right)$, soil temperature at $3 \mathrm{~cm}$ depth and thaw layer depth $(\mathrm{cm})$ during the July \& August field season at the six vegetation communities. The thaw layer depth was not separated for tussocks and hollow at the fen site. 36

Figure 2.5: Water table in reference to moss surface at fen site from July $15^{\text {th }}$ to August $30^{\text {th }}, 2008$. 37

Figure 2.6: Relationships between photosynthetically active radiation (PAR) and net ecosystem exchange of $\mathrm{CO}_{2}$ (NEE) at sites a) heath, b) shrub c) sedge tussock, d) sedge hollow, e) fen tussock f) fen hollow. Curves (solid lines) correspond to Equation 2.2 with the parameters listed in Table 2.4 and the mean chamber air temperature recorded during measurements. Negative values indicate net ecosystem carbon gain and positive values indicate net carbon loss by the ecosystem. 
Figure 2.7: Relationships between photosynthetically active radiation (PAR) and net ecosystem exchange of $\mathrm{CO}_{2}$ (NEE) at sites a) shrub sites 1 and 2 , in continuous shrub zone b) shrub sites 3 and 4, separated from continuous shrub zone. Curves are fit based on Equation 2.2. Negative values indicate net ecosystem carbon gain and positive values indicate net carbon loss by the ecosystem. 45

Figure 2.8: Average growing season $\mathrm{CO}_{2}$ and $\mathrm{CH}_{4}$ flux for each vegetation community. Error bars indicate \pm 1 standard error of the mean. Values for each variable that do not share superscript letters in common indicate significant differences between ecosystems (Tukey's HSD, $p<0.05$ ). Negative values indicate ecosystem uptake and positive values indicate loss by the ecosystem. 50

Figure 2.9: Average $\mathrm{CO}_{2}$ flux for each vegetation community \pm 1 standard error (SE) measured using the opaque static chamber system. 51

Figure 2.10: Average $\mathrm{CH}_{4}$ efflux for each vegetation community \pm 1 standard error of the mean (SE) where $n=4$ for each vegetation community site. Positive numbers indicate net carbon loss to the atmosphere and negative numbers indicate net ecosystem carbon gain.

Figure 2.11: $\mathrm{CO}_{2}$ and $\mathrm{CH}_{4}$ efflux from 8 am to $4 \mathrm{pm}$ over three days (squares, July $23^{\text {rd }}$, circles, August $17^{\text {th }}$ and triangles, August $28^{\text {th }}$ ) during the 2008 growing season \pm 1 standard error of the mean. 61

Figure 2.12: Average seasonal NEE, $\mathrm{CO}_{2}$ efflux and $\mathrm{CH}_{4}$ flux versus volumetric water content (VWC) $\left(\mathrm{m}^{3} \mathrm{~m}^{-3}\right) \pm 1$ standard error (SE) for each of the six vegetation 
communities. Negative values indicate ecosystem uptake and positive values indicate loss of carbon by the ecosystem. 66

Figure 3.1: Gas well for unsaturated soil (left). The installation of gas wells at 5 and 10 $\mathrm{cm}$ below the surface of a tussock (right). 89

Figure 3.2: Gas sampler for saturated soils at the fen hollow site. 91

Figure 3.3: Soil organic carbon $\left(\mathrm{kg} \mathrm{m}^{-3}\right)$ measurements from (a) heath, (b) shrub, (c) fen hollow, (d) sedge tussock and (e) fen tussock sites. The litter to soil interface is located at $0 \mathrm{~cm}$. Values are means \pm 1 standard error of the mean. 100

Figure 3.4: Total daily precipitation $(\mathrm{mm})$, water table in reference to moss surface at the fen site $(\mathrm{cm})$, average daily $\mathrm{u}$ (friction velocity) $\left(\mathrm{m} \mathrm{s}^{-1}\right)$ for day (solar radiation is greater than $\left.10 \mathrm{~W} \mathrm{~m}^{-2}\right)$ and night time periods, average soil temperature $\left({ }^{\circ} \mathrm{C}\right)$ at $3 \mathrm{~cm}$ depth at the six vegetation communities and average daily air temperature $\left({ }^{\circ} \mathrm{C}\right)$ at $1.5 \mathrm{~m}$ above the ground surface (solid line). Soil temperature values are means. Error bars are not shown for clarity. Std error for soil temperature was on average $0.8^{\circ} \mathrm{C}$ but as large as $3.4^{\circ} \mathrm{C} . .101$ Figure 3.5: Average daily volumetric water content $\left(\mathrm{VWC}, \mathrm{m}^{3} \mathrm{~m}^{-3}\right)$ at the a) heath, b) shrub, c) sedge tussock, d) fen tussock, e) sedge hollow and f) fen hollow during the 2008 field season. 102

Figure 3.6: Average seasonal subsurface $\mathrm{CH}_{4}$ concentration $\left(\mu \mathrm{mol} \mathrm{L}_{\mathrm{g}}{ }^{-1}\right.$ ) profiles for the a) heath and b) shrub site and $\mathrm{CO}_{2}$ concentration ( $\mu \mathrm{mol} \mathrm{L}_{\mathrm{g}}{ }^{-1}$ ) profiles for the c) heath and d) shrub site. Values are means \pm 1 standard error (SE) of the mean. Error bars are removed from profile $1 \mathrm{CH}_{4}$ concentrations at $5 \mathrm{~cm}$ for both the heath $\left(\mathrm{SE}=0.23 \mu \mathrm{mol} \mathrm{L}^{-1}\right)$ and shrub $\left(\mathrm{SE}=0.86 \mu \mathrm{mol} \mathrm{L}_{\mathrm{g}}^{-1}\right)$ sites for visual clarity. 104 
Figure 3.7: Subsurface $\mathrm{CO}_{2}$ concentration $\left(\mu \mathrm{mol} \mathrm{Lg}^{-1}\right)$ profiles for the a) heath and b) shrub site at 10,20 and $40 \mathrm{~cm}$ depth. Values are means \pm 1 standard error of the mean.

Figure 3.8: Subsurface $\mathrm{CH}_{4}$ concentration $\left(\mu \mathrm{mol} \mathrm{Lg}{ }^{-1}\right.$ ) profiles (in logarithmic scale) for the a) heath and b) shrub site at 5,20 and $60 \mathrm{~cm}$ depth. Error bars are not shown for clarity. Standard error was on average $0.14 \mu \mathrm{mol} \mathrm{L}_{\mathrm{g}}{ }^{-1}$ but as large as $2.28 \mu \mathrm{mol} \mathrm{L}{ }_{\mathrm{g}}^{-1} \ldots 106$ Figure 3.9: Average seasonal subsurface $\mathrm{CH}_{4}$ concentration profiles for the a) sedge tussock and b) fen tussock site and $\mathrm{CO}_{2}$ concentration profiles for the c) sedge tussock and d) fen tussock. Values are means \pm 1 standard error of the mean. 108 Figure 3.10: $\mathrm{CH}_{4}$ and $\mathrm{CO}_{2}$ concentration at 5 and $10 \mathrm{~cm}$ depths at each plot for the sedge tussock and fen tussock sites. 109 Figure 3.11: Average seasonal subsurface $\mathrm{CH}_{4}$ concentration profiles for the a) sedge hollow and b) fen hollow site and $\mathrm{CO}_{2}$ concentration profiles for the c) sedge hollow and d) fen hollow site. Values are means \pm 1 standard error of the mean. The $0-10,10-20,20$ $30,30-40 \mathrm{~cm}$ sampling intervals are represented by mid points of $-5,-15,-25$ and $-35 \mathrm{~cm}$ respectively on the y axis (depth).

Figure 3.12: $\mathrm{CH}_{4}$ and $\mathrm{CO}_{2}$ concentration profiles at the sedge hollow and fen hollow sites on July $14^{\text {th }}(196)$, July $25^{\text {th }}(207)$, August $10^{\text {th }}(223)$, August $15^{\text {th }}(228)$, and August $26^{\text {th }}$ (239) 2008. The $0-10,10-20,20-30,30-40 \mathrm{~cm}$ sampling intervals are represented by mid points of $-5,-15,-25$ and $-35 \mathrm{~cm}$ respectively on the y axis (depth).

Figure 3.13: Seasonal average $\mathrm{CH}_{4}$ flux and ebullition events as seen in diffusive chambers $\left(\mathrm{nmol} \mathrm{m} \mathrm{s}^{-1}\right)$ 123 


\section{LIST OF SYMBOLS AND ABBREVIATIONS}

\begin{tabular}{|c|c|c|}
\hline Symbol & Units & Definition \\
\hline$\alpha$ & $\mathrm{mol} \mathrm{CO}_{2} \mathrm{~mol}^{-1}$ photons & $\begin{array}{l}\text { effective quantum yield (sensitivity of NEE } \\
\text { to a change in light) }\end{array}$ \\
\hline A & $\mathrm{m}^{2}$ & chamber surface area \\
\hline $\mathrm{C}$ & & carbon \\
\hline $\mathrm{CO}_{2}$ & & carbon dioxide \\
\hline $\mathrm{CH}_{4}$ & & methane \\
\hline $\mathrm{CH}_{4}$ flux & $\mathrm{nmol} \mathrm{CH}_{4} \mathrm{~m}^{2} \mathrm{~s}^{-1}$ & methane flux \\
\hline $\mathrm{cm}$ & & centimetres \\
\hline $\mathrm{dx} / \mathrm{dt}$ & $\mathrm{ppm} \mathrm{s}^{-1}$ & change in concentration over time \\
\hline${ }^{\circ} \mathrm{C}$ & & degrees Celsius \\
\hline ER & $\mu \mathrm{mol} \mathrm{CO} 2 \mathrm{~m}^{2} \mathrm{~s}^{-1}$ & ecosystem respiration of $\mathrm{CO}_{2}$ \\
\hline GEP & $\mu \mathrm{mol} \mathrm{CO} 2 \mathrm{~m}^{2} \mathrm{~s}^{-1}$ & gross ecosystem photosynthesis \\
\hline GEPmax & $\mu \mathrm{mol} \mathrm{CO} 2 \mathrm{~m}^{2} \mathrm{~s}^{-1}$ & $\begin{array}{l}\text { gross ecosystem photosynthesis at } \\
\text { maximum PAR from field measurements }\end{array}$ \\
\hline$\overline{\text { GPmax }}$ & $\mu \mathrm{mol} \mathrm{CO} 2 \mathrm{~m}^{2} \mathrm{~s}^{-1}$ & $\begin{array}{l}\text { gross photosynthesis at maximum PAR } \\
\text { from model }\end{array}$ \\
\hline GWP & & global warming potential \\
\hline IRGA & & infrared gas analyser \\
\hline $\mathrm{km}$ & & kilometres \\
\hline LAI & $\mathrm{m}^{2}$ leaf area $\mathrm{m}^{-2}$ & leaf area index \\
\hline $\mathrm{m}$ & & meters \\
\hline $\min$ & & minutes \\
\hline $\mathrm{ml}$ & & millilitres \\
\hline $\mathrm{N}$ & & north \\
\hline NDVI & & normalized difference vegetation index \\
\hline
\end{tabular}




\begin{tabular}{|c|c|c|}
\hline NEE & $\mu \mathrm{mol} \mathrm{CO} 2 \mathrm{~m}^{2} \mathrm{~s}^{-1}$ & net ecosystem exchange of $\mathrm{CO}_{2}$ \\
\hline NEEmax & $\mu \mathrm{mol} \mathrm{CO} 2 \mathrm{~m}^{2} \mathrm{~s}^{-1}$ & $\begin{array}{l}\text { net ecosystem exchange of } \mathrm{CO}_{2} \text { at } \\
\text { maximum PAR }\end{array}$ \\
\hline N.W.T & & Northwest Territories, Canada \\
\hline $\mathrm{P}$ & $\mathrm{Pa}$ & atmospheric pressure \\
\hline PAR & $\mu \mathrm{mol}$ photons $\mathrm{m}^{2} \mathrm{~s}^{-1}$ & photosynthetically active radiation \\
\hline ppmv & & parts per million volume \\
\hline$\overline{Q_{10}}$ & & rate of increase in respiration over $10^{\circ} \mathrm{C}$ \\
\hline $\bar{R}$ & $\mathrm{~J} \mathrm{~mol}^{-1} \mathrm{~K}^{-1}$ & ideal gas constant, $8.3144 \mathrm{~J} \mathrm{~mol}^{-1} \mathrm{~K}^{-1}$ \\
\hline$\overline{R_{\text {ref }}}$ & $\mu \mathrm{mol} \mathrm{CO} 2 \mathrm{~m}^{2} \mathrm{~s}^{-1}$ & respiration at reference temperature Tref \\
\hline $\mathrm{R}_{10}$ & $\mu \mathrm{mol} \mathrm{CO} 2 \mathrm{~m}^{2} \mathrm{~s}^{-1}$ & respiration at reference temperature of $10^{\circ} \mathrm{C}$ \\
\hline $\mathrm{T}$ & $\begin{array}{l}{ }^{\circ} \mathrm{C} \\
\text { Kelvin }\end{array}$ & temperature \\
\hline Tref & ${ }^{\circ} \mathrm{C}$ & reference temperature, $10^{\circ} \mathrm{C}$ \\
\hline $\mathrm{T} 0 \mathrm{~cm}$ & ${ }^{\circ} \mathrm{C}$ & soil temperature at $0 \mathrm{~cm}$ \\
\hline $\mathrm{T} 3 \mathrm{~cm}$ & ${ }^{\circ} \mathrm{C}$ & soil temperature at $3 \mathrm{~cm}$ depth \\
\hline $\mathrm{T} 5 \mathrm{~cm}$ & ${ }^{\circ} \mathrm{C}$ & soil temperature at $5 \mathrm{~cm}$ depth \\
\hline $\mathrm{T} 6 \mathrm{~cm}$ & ${ }^{\circ} \mathrm{C}$ & soil temperature at $6 \mathrm{~cm}$ depth \\
\hline $\mathrm{T} 9 \mathrm{~cm}$ & ${ }^{\circ} \mathrm{C}$ & soil temperature at $9 \mathrm{~cm}$ depth \\
\hline $\mathrm{T} 10 \mathrm{~cm}$ & ${ }^{\circ} \mathrm{C}$ & soil temperature at $10 \mathrm{~cm}$ depth \\
\hline $\mathrm{T} 20 \mathrm{~cm}$ & ${ }^{\circ} \mathrm{C}$ & soil temperature at $20 \mathrm{~cm}$ depth \\
\hline $\mathrm{T} 30 \mathrm{~cm}$ & ${ }^{\circ} \mathrm{C}$ & soil temperature at $30 \mathrm{~cm}$ depth \\
\hline $\mathrm{T} 40 \mathrm{~cm}$ & ${ }^{\circ} \mathrm{C}$ & soil temperature at $40 \mathrm{~cm}$ depth \\
\hline $\mathrm{T} 50 \mathrm{~cm}$ & ${ }^{\circ} \mathrm{C}$ & soil temperature at $50 \mathrm{~cm}$ depth \\
\hline $\mathrm{T} 60 \mathrm{~cm}$ & ${ }^{\circ} \mathrm{C}$ & soil temperature at $60 \mathrm{~cm}$ depth \\
\hline
\end{tabular}

xvii 


\begin{tabular}{lll}
\hline $\mathrm{V}$ & $\mathrm{m}^{3}$ & chamber volume \\
\hline VWC & $\mathrm{m}^{3} \mathrm{~m}^{-3}$ & volumetric water content, $0-20 \mathrm{~cm}$ \\
\hline VWC $0 \mathrm{~cm}$ & $\mathrm{~m}^{3} \mathrm{~m}^{-3}$ & volumetric water content, surface \\
\hline VWC $5 \mathrm{~cm}$ & $\mathrm{~m}^{3} \mathrm{~m}^{-3}$ & volumetric water content, $5 \mathrm{~cm} \mathrm{depth}$ \\
\hline VWC $10 \mathrm{~cm}$ & $\mathrm{~m}^{3} \mathrm{~m}^{-3}$ & volumetric water content, $10 \mathrm{~cm}$ depth \\
\hline VWC $20 \mathrm{~cm}$ & $\mathrm{~m}^{3} \mathrm{~m}^{-3}$ & volumetric water content, $20 \mathrm{~cm}$ depth \\
\hline W & & west \\
\hline WT & & water table \\
\hline
\end{tabular}




\section{Introduction}

Arctic terrestrial ecosystems play an important role in the global carbon cycle due to the large quantity of carbon contained in arctic soils (Post et al., 1982). It is uncertain how present and future climate change may alter these large carbon stores. Changes to arctic carbon reservoirs that result in atmosphere-biosphere exchange of greenhouse gases such as methane $\left(\mathrm{CH}_{4}\right)$ and carbon dioxide $\left(\mathrm{CO}_{2}\right)$ have the potential for substantial positive and/or negative feedbacks on the global climate system (ACIA 2004; IPCC, 2007). In order to more adequately predict how arctic carbon cycling will change we must monitor current conditions. This will facilitate an improvement in our understanding of arctic carbon cycling dynamics and aid in predicting future changes in these northern regions.

Arctic ecosystems consist of a heterogeneous mix of vegetation types over short distances as a function of topographic variation, sometimes on scales of centimetres and associated soil moisture conditions. Processes controlling arctic terrestrial carbon dynamics are complex and also vary over a range of spatial and temporal scales. This causes the exchanges of $\mathrm{CH}_{4}$ and $\mathrm{CO}_{2}$ between the tundra and the atmosphere to be highly variable across arctic landscapes (Christensen et al., 2000; Corradi et al., 2005). This leads to significant uncertainty when trying to predict how the carbon budget of this landscape may respond to short-term variations in weather and long-term climate change.

Definitions of the southern boundary of the Arctic vary according to environmental, geographic, or political biases. From the perspective of biogeochemical cycling, the environmental definition of arctic tundra defines the southern limit as the northern extent 
of the closed boreal forest (taiga) (ACIA, 2004). The Arctic is characterized by extreme climate with strong seasonality in temperature and incoming radiation (Overpeck et al., 1997; Sjögersten et al., 2006). These northern environments experience longer day times throughout the summer, and shorter day times in winter in comparison with southern ecosystems. Arctic tundra landscapes are snow covered for much of the year, insulating the ground from low air temperatures. The short growing season begins with spring thaw when air temperature rises above zero. The end of the growing season occurs as the amount of incoming solar radiation declines, plants senesce, soils freeze and the ground becomes snow covered (Harding et al., 2001).

The arctic terrestrial landscape is known as tundra, a treeless terrain with vegetation adapted to the extreme environments consisting primarily of grasses, sedges, small flowering herbs, low shrubs, lichens and mosses (Bartlett \& Harris, 1993; Kutzbach et al., 2007). There is a mosaic of ecosystem types, which are governed by climatic and hydrologic gradients. These gradients form dry tundra, where vegetation covers less than $50 \%$ of the ground surface, mesic tundra that is highly vegetated with temporal water inputs, and wet tundra ecosystems (Welker et al., 2004).

The presence of permafrost, defined as subsurface ground that remains at or below $0^{\circ} \mathrm{C}$ for two or more years, is widespread in the Arctic (Metje \& Frenzel, 2007). The concentration of wetlands is high due to the presence of permafrost which impedes drainage (Bartlett \& Harris, 1993) and as a result, peat forming wetlands (peatlands) are widespread in the low arctic. 
In the spring as the temperature rises, soils begin to thaw, increasing thaw depth (Weller et al., 1995). The depth of the active layer depends on growing season temperatures and topography, with a typical range of $40-80 \mathrm{~cm}$ (ACIA, 2004). The active layer becomes saturated with snowmelt and the combination of low evaporation rates and impeded drainage due to permafrost means much of the land surface becomes saturated. Upland soils and hill slopes drain relatively quickly while lowland areas may become saturated with water throughout the growing season. Microtopography over centimetres to meters may occur due to frost heave and subsequent influences of vegetation and water movement.

Climate change is predicted to cause earlier and more drastic environmental changes to terrestrial arctic ecosystems than elsewhere on the planet (Roulet et al., 1992; Maxwell, 1997). General circulation models predict that increasing arctic surface temperatures will cause earlier and increased rates of spring snow melt and a delay of accumulation in the fall, lengthening the growing season by $20-40 \%$ depending on the latitude (Maxwell, 1992). In recent decades, arctic surface air temperatures have warmed at approximately twice the global rate with strongest warming rates in winter and spring (ACIA, 2004). As a consequence of warming, arctic permafrost degradation is widespread with reduction in area and extensive thickening of the active layer (IPCC, 2007). Over the past decade, vegetation changes have occurred in tussock tundra with an increase in deciduous shrubs and decline in sedges (Sturm et al., 2001). These ecosystem shifts may change the ecological functioning of arctic ecosystems. 
Arctic ecosystems have been identified as regions with the greatest potential to affect global climate (ACIA, 2004). Environmental changes in terrestrial arctic ecosystems may cause both positive and negative climate feedbacks at regional and global scales. One mechanism for this is through changes in terrestrial arctic carbon cycling. Extensive permafrost degradation and active-layer thickening could newly expose great amounts of soil organic carbon to decomposition (Schuur et al., 2008). Increased emissions of greenhouse gases, $\mathrm{CO}_{2}$ and $\mathrm{CH}_{4}$, may occur in various areas of the Arctic (Weller et al., 1995; Dutta et al., 2006). The release of these greenhouse gases will cause a positive feedback to global warming. However, the potential for extended growing seasons and vegetation shifts could increase the net uptake of $\mathrm{CO}_{2}$ by these ecosystems. Due to the large complexity of feedback interaction processes and insufficient data, future arctic impacts are difficult to predict (ACIA, 2004). In order to improve predictions of future climatic feedbacks it is important to increase our understanding of the factors controlling carbon cycling in arctic areas (Hobbie et al., 2000).

The arctic plays a significant role in the global carbon cycle given that it covers approximately $5 \%$ of global land area but it stores around $14 \%$ of global organic carbon, most of which is in frozen peat (Post et al., 1982). The amount of carbon per unit area is $50 \%$ higher than the global average (Jonasson et al., 2001). Recently, estimates have placed $45 \%$ of the world's soil carbon from 0-3 $\mathrm{m}$ in permafrost soils (Jobbágy \& Jackson, 2000; Schuur et al., 2008).

Arctic ecosystems have sequestered carbon as a result of a small but persistent imbalance between $\mathrm{CO}_{2}$ uptake through photosynthesis and carbon losses through 
decomposition and respiration including gaseous losses of $\mathrm{CO}_{2}$ and $\mathrm{CH}_{4}$ and water-borne losses of dissolved organic carbon. In the arctic, this imbalance is due to factors that inhibit decomposition including low temperatures, waterlogged conditions and poor substrate quality (Hobbie, 1996). Additionally, cryoturbation is an important process that enables organic carbon from surface horizons to be mixed into the soil profile and stabilized in frozen horizons for extended periods of time or incorporated into the permafrost (Hobbie et al., 2000).

Ecosystems may be a source (net release) or a sink (net uptake) of carbon depending on weather conditions (ACIA, 2004). Ecosystems with different hydrology differ dramatically in carbon storage with wet systems having a large sink potential and welldrained areas being weaker sinks or sources of carbon (Jones et al., 1998; Soegaard et al., 2000; McFadden et al., 2003; Groendahl et al., 2007). The majority of carbon storage is in low-lying, poorly-drained, wet meadow and tussock tundra dominated by sedges (e.g. fens, wet meadows, tussock tundra) (Hobbie et al., 2000; Harding et al., 2001; Jonasson et al., 2001). Extensive cool, waterlogged landscapes create anoxic conditions that reduce decomposition rates, result in peat formation (carbon storage) and act as a source of $\mathrm{CH}_{4}$ (Davidson \& Janssens, 2006). Relatively drier soils have less carbon accumulation. The maximum concentration of carbon in drier soils is in the surface layers and decreases with depth, with the exception of buried organic rich layers, caused by cryoturbation (Elberling et al., 2004).

In the arctic, $\mathrm{CO}_{2}$ and $\mathrm{CH}_{4}$ fluxes are influenced by a multitude of abiotic and biotic factors including temperature, thaw depth, water table position, growing season length, 
precipitation, microtopography and plant species and productivity (Christensen $e t$ al., 2000). Measurements show great spatial variability in the magnitude of sink/source status for carbon, with no overall trend for the Arctic (Corradi et al., 2005). Interannual ecosystem responses to variation in weather variables are diverse, causing some areas to be net carbon sources in some years and sinks in others (Zimov et al., 1996; Oechel et al., 2000).

In the arctic, the rate of photosynthetic uptake of atmospheric $\mathrm{CO}_{2}$ by plants, also known as gross ecosystem (or primary) production (GEP), varies depending on the species (ACIA, 2004) but is confined to a short growing season due mainly to limited incoming radiation with only some limitations due to temperature when these fall below threshold values (van der Molen et al., 2007). There is a wide range of variation in GEP within the arctic. In general, productivity decreases from south to north, but local variation in relation to topography is dramatic (ACIA, 2004).

The production of $\mathrm{CO}_{2}$ can occur via several biochemical processes including aerobic respiration and oxidation of $\mathrm{CH}_{4}$ to $\mathrm{CO}_{2}$ and anaerobic fermentation of glucose to organic acids. Ecosystem respiration under aerobic conditions is a multistep catabolic process that breaks down glucose and other organic fuels releasing $\mathrm{CO}_{2}$ as a by-product (Luo \& $\mathrm{Zhou}$, 2006). Ecosystem respiration of $\mathrm{CO}_{2}$ can be partitioned to autotrophic respiration (plant respiration) and heterotrophic respiration (microorganism respiration). Autotrophic respiration is controlled by the metabolic processes of plants and consequently is tightly linked to plant productivity and the abiotic factors influencing growth including temperature and nutrient and moisture availability. Heterotrophic respiration is dependent 
on substrate quality and availability, temperature and the volumetric water content of soil (Griffis et al., 2004; Elberling, 2007).

Soil respiration leads to high $\mathrm{CO}_{2}$ concentrations in the subsurface, resulting in a large concentration gradient between the soil and the atmosphere driving diffusive efflux (Elberling et al., 2004). Gas transport through the soil is a function of texture, porosity and soil water content (Whalen \& Reeburgh, 1990; Luo \& Zhou, 2006). Atmospheric turbulence enhances mixing of trace gasses in the atmosphere, increasing the surfaceatmosphere concentration gradient and increasing fluxes (Lafleur, 2009).

The net ecosystem $\mathrm{CO}_{2}$ exchange (NEE) is defined here as the difference between GEP and ER. During the daytime, NEE is negative while photosynthesis exceeds respiration rates and after sunset when photosynthesis ceases, NEE is positive (Nordström et al., 2001; Oechel et al., 2000; Soegaard et al., 2000). The annual NEE of arctic ecosystems is largely controlled by incoming radiation, temperature and precipitation (Lloyd, 2001; Sjögersten et al., 2006).

Methane emissions from arctic tundra ecosystems is estimated to account for $10 \%$ of global sources (Reeburgh \& Whalen, 1992). Methane emission to the atmosphere is the difference between $\mathrm{CH}_{4}$ that is produced and oxidized. The production, consumption and transport of $\mathrm{CH}_{4}$ are governed by interrelated environmental factors including microbial community structure, climate, soil properties, and vegetation (Kutzbach et al., 2004).

There are two main pathways of $\mathrm{CH}_{4}$ production in anaerobic soils, the reduction of $\mathrm{CO}_{2}$ to $\mathrm{CH}_{4}$ by methanogenic microbes, Archaea and the fermentation of acetate to $\mathrm{CO}_{2}$ 
and then to $\mathrm{CH}_{4}$ (Liebner \& Wagner, 2007; Rinne et al., 2007). Methanogenesis is controlled by a range of factors including temperature, persistence of anaerobic conditions, and supply of substrates (Schimel, 1995; Joabsson \& Christensen, 2001). Decomposition of fresh root litter, root exudates, and respiration provide substrates for microorganisms (Metje \& Frenzel, 2007). Methanogenic bacteria may be limited by substrate availability because organic material at depth where methanogenesis takes place is recalcitrant, therefore fresh carbon compounds in labile pools are an important source for $\mathrm{CH}_{4}$ production (Joabsson \& Christensen, 2001).

Once $\mathrm{CH}_{4}$ is produced in an anaerobic zone it may become oxidized as it diffuses through an aerobic top layer by methanotrophic bacteria before reaching the surface, causing these zones to be a sink for $\mathrm{CH}_{4}$ (Hanson \& Hanson, 1996; Whalen \& Reeburgh, 1990). When the water table is near the surface the potential for $\mathrm{CH}_{4}$ oxidation is minimized allowing for large $\mathrm{CH}_{4}$ emissions. Consumption of $\mathrm{CH}_{4}$ depends on transport to zones of oxidation. Methanotrophy in aerobic layers may be responsible for the oxidation of approximately $50 \%$ of the $\mathrm{CH}_{4}$ produced in lower anaerobic layers (ACIA, 2004). As a result, methanotrophy is as important to net $\mathrm{CH}_{4}$ emissions as methanogenesis.

Plants facilitate the exchange of $\mathrm{CH}_{4}$ and oxygen between below ground and the atmosphere via aerenchyma tissue. Plants also provide substrates for $\mathrm{CH}_{4}$ production through root respiration and exudation of $\mathrm{CO}_{2}$ (Torn \& Chapin, 1993; King et al., 1998). Transport of $\mathrm{CH}_{4}$ by vascular plants may bypass the aerobic oxidation zone, while transport of oxygen to the subsurface may lead to $\mathrm{CH}_{4}$ oxidation (Watson et al., 1997; 
Kutzbach et al., 2004). Most studies have found that the presence of vascular vegetation with aerenchyma tissue such as sedges increases the emission of $\mathrm{CH}_{4}$ from wet arctic tundra (Whalen \& Reeburgh, 1990; Torn \& Chapin, 1993; Schimel, 1995; King et al., 1998). Additionally ebullition may account for a large proportion of $\mathrm{CH}_{4}$ and $\mathrm{CO}_{2}$ emissions in wet systems (ACIA, 2004). Gas bubbles containing high concentrations may be episodically released to the atmosphere by triggers such as barometric pressure (Tokida et al., 2007).

Throughout the growing season, variation in spatial and temporal $\mathrm{CH}_{4}$ flux can often be attributed to the following parameters, temperature, water table depth, substrate production and vascular plant development (MacDonald et al., 1998; Hargreaves et al., 2001). Emissions are expected to decline steadily as soil temperature decreases nearing the end of the growing season (Christensen et al., 2004).

In addition to providing information about the carbon balance of an ecosystem, the proportions of $\mathrm{CO}_{2}$ and $\mathrm{CH}_{4}$ are of great importance in determining the radiative forcing potential of these landscapes. The majority of carbon lost is due to respiration of $\mathrm{CO}_{2}$, while $\mathrm{CH}_{4}$ emissions are approximately $5 \%$ of $\mathrm{CO}_{2}$ emissions (ACIA, 2004). However, the greenhouse warming potential of $\mathrm{CH}_{4}$ is 21 times greater than $\mathrm{CO}_{2}$, on a per molecule basis over a 100 year time period (IPCC, 2007). As a result, although $\mathrm{CH}_{4}$ fluxes rarely make up a significant proportion of the total carbon budget on a mass basis, these relatively small fluxes may offset $\mathrm{CO}_{2}$ uptake from a greenhouse gas forcing perspective. However, it is also important to understand that the contribution of the greenhouse gas 
exchanges for a given ecosystem needs to be evaluated over the lifetime of the ecosystem (Frolking et al., 2006).

Within the Canadian Arctic, a number of studies have examined small scale fluxes of both $\mathrm{CO}_{2}$ and $\mathrm{CH}_{4}$ (Mayo et al., 1973; Welker et al., 2004; Oberbauer et al., 2007) but few studies have been located within the unique climate and physiography of Canada's central Arctic (Liblik et al., 1997; Nobrega \& Grogan, 2008). In 2004, Canadian Tundra Ecosystem Carbon Study (Lafleur \& Humphreys, 2008) was established at Daring Lake, N.W.T (64.52' $\mathrm{N}, 111^{\circ} 34^{\prime} \mathrm{W}$ ) to provide long-term monitoring of $\mathrm{CO}_{2}$ and energy exchanges between arctic tundra and the atmosphere using a comprehensive set of methods including tower-based eddy covariance flux measurements (ecosystem scale), small chamber (plot scale) and manipulation experiments.

Daring Lake is located within the Coppermine River drainage basin, approximately $300 \mathrm{~km}$ northeast of Yellowknife, N.W.T (Figure 1.1). It is situated in the Canadian Southern Arctic Ecozone (also referred to as the 'barrens'), and located approximately 75 $\mathrm{km}$ north of the tree line. The landscape is characterized by treeless tundra with numerous Canadian Shield outcrops, esker complexes and lakes formed due to the movement of glaciers in the last ice age (Environment Canada, 2005). Soils have formed from till and glaciofluvial materials causing soils to generally have a coarse texture with lots of sand and a considerable amount of silt which makes them susceptible to cryoturbation (Tarnocai, 2004). The landscape is underlain with continuous permafrost with active layer depth depending on growing season temperatures and topography, with a typical 


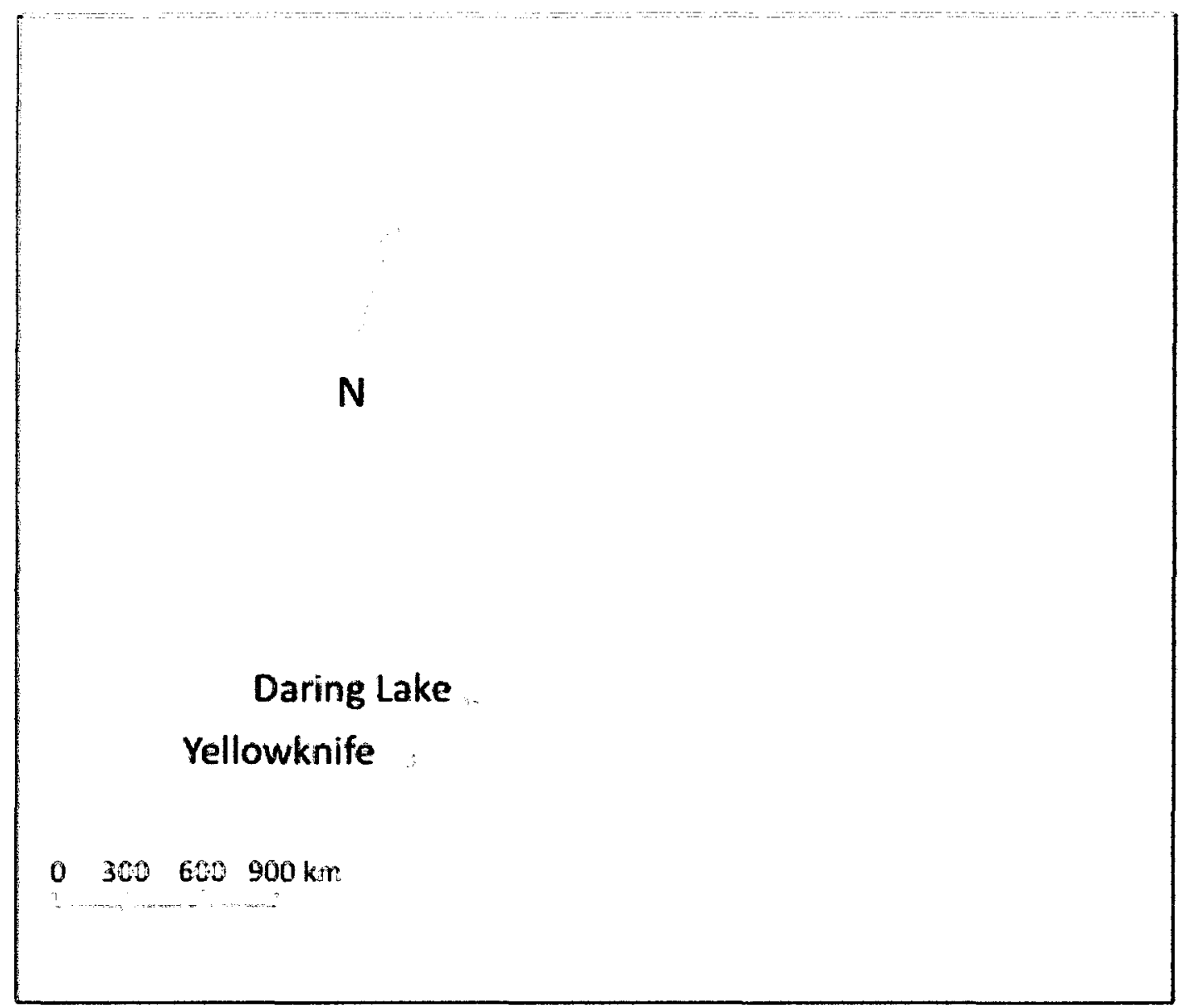

Figure 1.1: Location of the Daring Lake research site in the Northwest Territories. 
range of 0.3-1.2 m (Dredge et al., 1999). The active layer becomes saturated after spring thaw. Upland areas drain quickly while the combination of low evaporation rates and impeded drainage due to permafrost means much lowland areas are saturated throughout the growing season. The climate in this area is characterized by long winters and short snow free growing seasons (mid June to early September). Mean annual temperature in the region is $-13^{\circ} \mathrm{C}$ and annual precipitation ranges between $200-400 \mathrm{~mm}$ (Lafleur \& Humphreys, 2008). The Bathurst caribou herd migrates through this area in the spring and fall to and from their summer calving grounds in the northern fringe of the Ecozone to their winter range in the taiga forest (Environment Canada, 2005).

In order to improve estimates of the quantity of and environmental controls on the atmospheric exchange of $\mathrm{CO}_{2}$ and $\mathrm{CH}_{4}$ in Canada's Southern Arctic Ecozone, this study examined fluxes and subsurface concentrations of $\mathrm{CO}_{2} \& \mathrm{CH}_{4}$ for six different vegetation community plots at Daring Lake during the 2008 growing season. Vegetation community plots included heath and shrub tundra, sedge tussock and hollows and fen tussock and hollows. These measurements were made to specifically address a number of research hypotheses regarding $\mathrm{CO}_{2}$ and $\mathrm{CH}_{4}$ exchange in the Daring Lake area that have important implications for our ability to not only assess the carbon budget of a small arctic watershed but also to assess the role of arctic carbon cycling on global climate change. These hypotheses include:

1. $\mathrm{CO}_{2}$ and $\mathrm{CH}_{4}$ fluxes and their subsurface concentrations at six vegetation community types at Daring Lake are both spatially and temporally variable. 
2. Spatial variations in both $\mathrm{CO}_{2}$ and $\mathrm{CH}_{4}$ fluxes can be related to variations in soil moisture.

3. Temperature and soil moisture variations are similarly important in determining temporal variations in $\mathrm{CO}_{2}$ and $\mathrm{CH}_{4}$ fluxes in all vegetation community types. Measurements of $\mathrm{CO}_{2}$ and $\mathrm{CH}_{4}$ exchanges in arctic tundra are critically important in order to attempt to answer these questions which speak to the complexity of this system. Ultimately an understanding of this complexity will influence our ability to model the arctic carbon cycle and predict how this vast ecosystem may respond and feedback on global climate change.

In Chapter 2, the spatial and temporal variability of surface-atmosphere fluxes of $\mathrm{CO}_{2}$ and $\mathrm{CH}_{4}$ are examined among and within vegetation community plots and are related to various environmental variables. These fluxes were also used to model the July/August 2008 carbon balance and global warming potential of these six vegetation communities. In Chapter 3, the temporal and spatial variability of subsurface concentrations of $\mathrm{CO}_{2}$ and $\mathrm{CH}_{4}$ was examined and related to environmental variables for the same six vegetation community plots from Chapter 2. Profiles of subsurface $\mathrm{CO}_{2}$ and $\mathrm{CH}_{4}$ concentrations were used to identify important controls on production, oxidation and transport of these greenhouse gases. A summary of the major results of this study and potential areas for further research examining carbon dynamics in arctic ecosystems are identified in Chapter 4. 


\section{Fluxes of Carbon Dioxide and Methane from a Variety of Tundra Vegetation Communities in the Southern Canadian Arctic}

\subsection{Introduction}

Arctic landscapes store large amounts of carbon due to factors that inhibit decomposition including low temperatures, poor substrate quality and waterlogged conditions attributable to the presence of permafrost which impedes drainage (Bartlett \& Harris, 1993; Hobbie, 1996). The carbon balance of arctic ecosystems has been largely examined in terms of the atmospheric exchange of carbon dioxide $\left(\mathrm{CO}_{2}\right)($ e.g. Jones et al., 1998; Oberbauer et al., 1996; Illeris et al., 2004; Groendahl et al., 2007; Fox et al., 2008). However, waterlogged arctic environments also create anaerobic conditions within the soil that result in the production of methane $\left(\mathrm{CH}_{4}\right)$, a greenhouse gas with a stronger radiative forcing potential than $\mathrm{CO}_{2}$. Climate change is associated with rising air and soil temperatures, extensive permafrost degradation and changes in precipitation patterns, all of which have the potential to alter the arctic carbon balance (Dutta et al., 2006). Substantial change in the tundra-atmosphere exchange of $\mathrm{CO}_{2}$ and $\mathrm{CH}_{4}$ also has the potential for significant feedback effects on global climate (IPCC, 2007). To improve predictions of how climate change will modify the arctic carbon balance, quantification of current $\mathrm{CO}_{2}$ and $\mathrm{CH}_{4}$ exchange and an enhanced understanding of controls on carbon cycling mechanisms for arctic terrestrial ecosystems are required.

Across the arctic landscape, climatic and hydrological gradients create a patchwork of vegetation communities, ranging from dry upland tundra to wet lowland 
tundra (Welker et al., 2004). This heterogeneity has led to highly variable carbon exchange between the tundra and the atmosphere over small spatial scales (Christensen $e t$ al., 2000; Corradi et al., 2005). Small scale heterogeneity of hydrology, soil temperature, texture, organic matter content, active layer depth, soil moisture and water table depth have complex interactions making it difficult to measure and attribute individual influences on carbon exchange processes (van der Molen et al., 2007).

Differences in ecosystem type are important in determining carbon exchange. Wet ecosystems have the potential for substantial $\mathrm{CO}_{2}$ gain (Christensen et al., 2000;

Heikkinen et al., 2002) and $\mathrm{CH}_{4}$ loss (Christensen et al., 2000) across a wide range of temperatures. Drier sites tend to be either sources or small sinks of $\mathrm{CO}_{2}$ and tend to show increasing $\mathrm{CO}_{2}$ losses with increasing temperature due to enhanced respiration rates (Jones et al., 1998; Christensen et al., 2000; Kwon et al., 2006). As a result, carbon storage generally increases along transects from dry uplands to wet lowlands (Soegaard et al., 2000; Elberling et al., 2004; Sjögersten et al., 2006).

The spatial variability of carbon exchange within a valley in Canada's Southern Arctic Ecozone was investigated by measuring fluxes of greenhouse gases $\mathrm{CO}_{2}$ and $\mathrm{CH}_{4}$ at six vegetation communities at Daring Lake, N.W.T. The objectives of this study were 1) to assess the temporal and spatial variability of $\mathrm{CO}_{2}$ and $\mathrm{CH}_{4}$ flux within different arctic tundra ecosystems and 2) investigate the mechanisms that control $\mathrm{CO}_{2}$ and $\mathrm{CH}_{4}$ flux. 
Two micrometerological towers in the research area have been measuring tundraatmosphere exchanges of $\mathrm{CO}_{2}$ and water vapour at the ecosystem scale ( $>1$ ha area) since 2004 and 2006. One tower is located at a fen site, which has tussock and hollow topography and is dominated by mosses and sedges. The other tower is located within an upland area characterized by a mixture of mesic lichen heath mat tundra and shrubhummock tundra (Lafleur \& Humphreys, 2008). The measurements from these towers suggest that over a 3 -year period, growing season (May $15^{\text {th }}$ to August $31^{\text {st }}$ ) $\mathrm{CO}_{2}$ uptake is greater in the fen $\left(85 \pm 13 \mathrm{~g} \mathrm{C} \mathrm{m}^{-2}\right.$, mean \pm 1 std. error) than in the mixed tundra $(66 \pm 3 \mathrm{~g}$ $\left.\mathrm{C} \mathrm{m}^{-2}\right)$.

Measurements of fluxes of $\mathrm{CO}_{2}$ and $\mathrm{CH}_{4}$ at the smaller plot scale $\left(\sim 0.07 \mathrm{~m}^{2}\right)$ using chamber techniques within the fetch of the towers were used to provide further understanding of component processes of this larger scale carbon exchange. For example, chamber measurements were used to identify which vegetation communities are responsible for the greatest $\mathrm{CO}_{2}$ and $\mathrm{CH}_{4}$ emissions and which respond most to seasonal variations in temperature and moisture. Additionally, as ecosystem scale fluxes of $\mathrm{CH}_{4}$ have yet to be assessed with micrometeorological techniques nor have chamber measurements been made within the fetch of these towers, measurements of $\mathrm{CH}_{4}$ flux will provide a more complete picture of the total carbon budget and the radiative forcing potential of these sites. 


\subsection{Materials and Methods}

\subsubsection{Site Description}

The study is located at the Tundra Ecological Research Station (TERS) at Daring Lake, Northwest Territories, Canada $\left(64^{\circ} 52^{\prime} \mathrm{N}, 111^{\circ} 34^{\prime} \mathrm{W}\right)$. It is approximately $300 \mathrm{~km}$ northeast of the territorial capital, Yellowknife, within the Coppermine River drainage basin and is in the Southern Arctic Ecozone. The research area is located within a 1.5 $\mathrm{km}$ long, $\sim 1 \mathrm{~km}$ wide valley between Daring Lake and a small lake with $\sim 45 \mathrm{~m}$ elevation difference between the bottom of the valley and top of the northern esker (Figure 2.1). Research activities occurred in collaboration with the Canadian Tundra Ecosystem Carbon Study established in 2004 at Daring Lake (Lafleur \& Humphreys, 2008).

The climate in this area is characterized by short, snow-free, growing seasons (typically mid June to early September) with short transitions of snow melt and freeze up. Mean annual temperature in the region is $-13^{\circ} \mathrm{C}$ and annual precipitation ranges between 200-400 mm (Lafleur \& Humphreys, 2008; Natural Resources Canada, 2009). The region is underlain with continuous permafrost with a shallow active layer reaching 0.3 $1.2 \mathrm{~m}$ (Dredge et al., 1999). In 2008 the average July and August temperature was $12^{\circ} \mathrm{C}$. 2008 was a relatively wet summer with $142 \mathrm{~mm}$ in July and August.

To quantify the small scale variability in $\mathrm{CO}_{2}$ and $\mathrm{CH}_{4}$ flux in this region, six vegetation community plots were selected to best represent the variability of vegetation and microtopography within the fetch of the two previously installed 


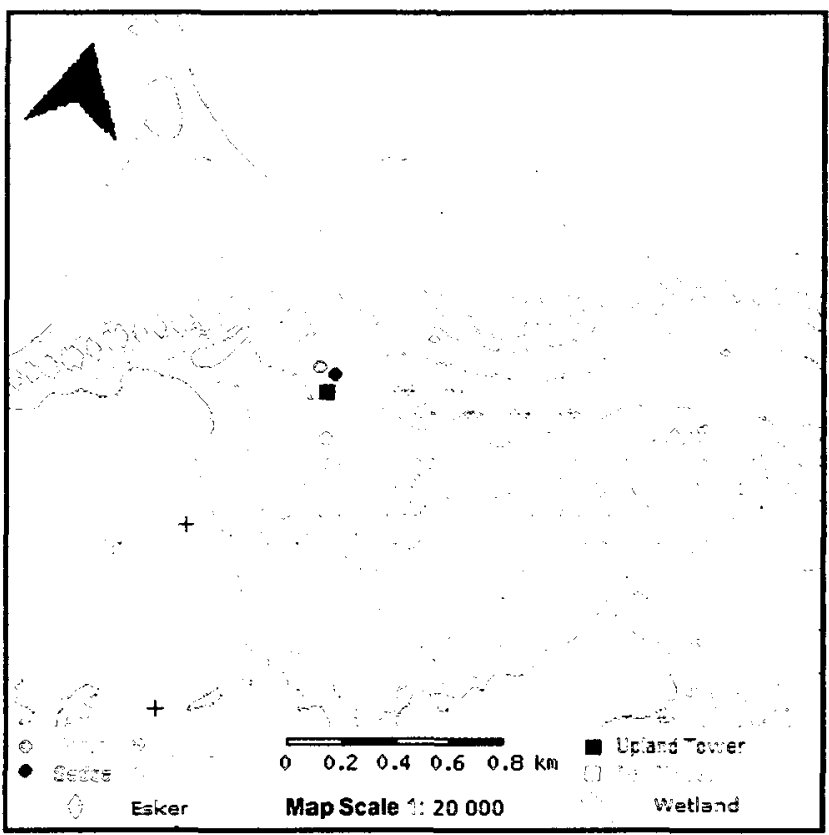

Figure 2.1: Map of the research valley at Daring Lake, N.W.T with site locations (http://atlas.nrcan.gc.ca). 
micrometeorological towers (Figure 2.1 \& Figure 2.2). Four vegetation community plots selected within the upland mixed tundra tower area included dry heath, dwarf shrub hummock and sedge tussocks and sedge hollows located in a small wet area. Two vegetation community plots selected within the fen tower area included tussocks and hollows. At both the sedge and fen areas tussocks and hollows were studied separately to examine the effects of microtopographical heterogeneity on carbon exchange processes in these wet arctic environments.

The dry heath tundra site was located in an upland area and had a shallow organic layer $(2-5 \mathrm{~cm})$ with well drained sandy loam soil. Vegetation consisted of mat-forming evergreen ericaceous shrubs (Ledum decumbens (Ait.), Vaccinium vitis-idaea (L.), and Empetrum nigrum (L.)), deciduous shrubs (Vaccinium uliginosum (L.)), Betula glandulosa (Michx.), and Rubus chamaemorus (L.)), graminoids (Carex sp. (L)), lichen cover (Cetraria nivalis (L.), Briocaulon divergens (Ach.), Cladina mitis, Cladina rangiferina (L.)) and a small portion of unidentified mosses (Lafleur \& Humphreys, 2008).

The dwarf shrub hummock tundra site was located on lowland tundra $\sim 200 \mathrm{~m}$ away from the heath and sedge sites and had a variable organic layer $(0-10 \mathrm{~cm})$ and soil with loamy sand texture. Vegetation consisted of a variety of shrubs (L. decumbens (Ait.), B. glandulosa (Michx.), V. vitis-idaea (L.), V. uliginosum (L.), Arctostaphylos alpina (L.)), graminoids (Eriophrum vaginatum (L.)), lichen (Alectoria ochroleuca (Hoffm.), C. nivalis (L.), B. divergens (Ach.), C. rangiferina (L.)) and a well-developed moss layer (Sphagnum spp. and Aulacomnium turgidum (Wahlenb.)). 


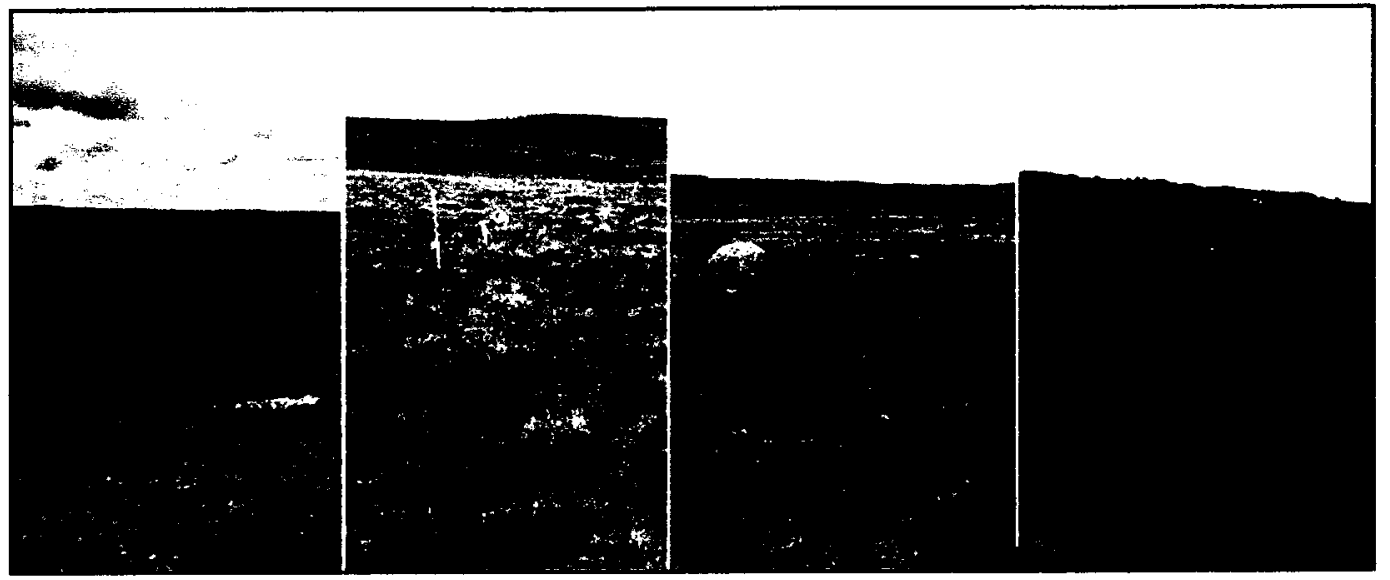

Figure 2.2: Vegetation community plots left to right: heath, sedge (tussock $\&$ hollow), shrub and fen (tussock \& hollow). 
The sedge tussock and hollow sites were located $\sim 40 \mathrm{~m}$ away down a slight slope from the heath site. The surrounding topography caused drainage into this small water logged area. It had tussock and hollow topography with vegetation dominated by sedges (Carex spp., Eriophorum spp. (L.)) and mosses (Sphagnum spp., Aulacomnium turgidum (Wahlenb.)) with occasional ericaceous shrubs (Andromeda polifolia (L.), and $L$. decumbens (Ait.)). The peat depth varied from 40-60 cm.

The fen tussock and hollow sites were located in a large fen peatland which extended along the bottom of the valley $\sim 1.3 \mathrm{~km}$ long, $\sim 325 \mathrm{~m}$ wide, approximately 560 $\mathrm{m}$ SE from the 4 sites associated with the upland flux tower. Vegetation was dominated by sedges (Carex spp., Eriophorum spp. (L.)) with small amounts of $A$. polifolia (L.), and a well developed ground cover of mosses (Sphagnum spp.). The peat depth varied from $50-70 \mathrm{~cm}$.

\subsubsection{Data Collection}

Most studies examining $\mathrm{CO}_{2}$ and $\mathrm{CH}_{4}$ flux from arctic tundra have been conducted with chambers (e.g. Torn \& Chapin 1993; Whiting, 1994; Schimel 1995; Christensen et al., 1996; King et al., 1998; Nakano et al., 2000; Wagner et al., 2003). Advantages of this method include the relatively low cost, low maintenance and small power consumption required, making this method well suited to flux measurements in remote areas. This small scale measurement technique can be used for detailed research examining processes controlling $\mathrm{CO}_{2}$ and $\mathrm{CH}_{4}$ flux. 
Four permanent chamber flux sampling locations were established at each of the six vegetation communities by installing collars into representative areas (PVC SDR-35 sewer pipe diameter $29.5 \mathrm{~cm}$ and an area of $683.5 \mathrm{~cm}^{2}$ ). At the dry heath and mesic dwarf shrub sites collars were $6 \mathrm{~cm}$ in height, while at the wet tussock hollow sites collars were $12 \mathrm{~cm}$ in height. The shorter collars were used at the dry sites to decrease soil and plant root damage. The taller collars were installed in peat layers and needed to be deep enough to ensure $\mathrm{CO}_{2}$ and $\mathrm{CH}_{4}$ would not diffuse out laterally through the highly porous peat below the collar. All vegetation was guided up through the collar before cutting with a knife around the collar for installation. At both the sedge and fen sites 4 collars were installed in tussocks and 4 collars were installed in between the tussocks in lower lying hollows. A water seal was used to limit the potential for leaks between the collar and chamber when making gas flux measurements. This involved pouring water into a groove on the collar rim and inserting the chamber into the groove.

\section{NEE Chamber System}

A closed, non-steady state chamber system was used to measure the net ecosystem exchange of $\mathrm{CO}_{2}$ (NEE) and develop relationships between NEE and light and temperature. These measurements were achieved by operating the chamber system under four varying light levels. First the clear chamber was uncovered then single and double layers of standard $50 \%$ shading cloth covered the chamber, and finally a layer of heavy duty black plastic garbage bags created opaque conditions. Ecosystem respiration of $\mathrm{CO}_{2}$ (ER) was measured under opaque conditions and gross ecosystem production (GEP) was 
estimating using NEE and ER measurements. At each light level concentrations of $\mathrm{CO}_{2}$ were measured for $2 \mathrm{~min}$. In between sampling periods, the system was left to equilibrate with ambient $\mathrm{CO}_{2}$ concentrations (usually between 370 and $380 \mathrm{ppmv}$ ). To relate $\mathrm{CO}_{2}$ concentrations to the varying light levels, a quantum sensor (model LI-190, LI-COR Inc., Lincoln, USA) affixed to a tripod measured photosynthetically active radiation (PAR). To ensure that PAR values from the quantum sensor were comparable to the PAR which vegetation plots would receive during runs, PAR values were adjusted to $92 \%$ to account for attenuation during transmission through the acrylic chamber (Kim et al., 2004). Independent tests confirmed that $90-92 \%$ of total incident PAR was measured inside the chamber. $\mathrm{CO}_{2}$ fluxes were measured using a closed path infra-red gas analyser (IRGA) (LI-840, LI-COR Inc., Lincoln, NE, USA) attached to an acrylic chamber with a volume of $0.0246 \mathrm{~m}^{3}$. Located inside the chamber was a fine wire thermocouple which measured chamber air temperature, a Peltier cooler which kept the air temperature in the chamber to within $\pm 2{ }^{\circ} \mathrm{C}$ of ambient conditions, and a mixing fan which continually mixed air inside the chamber during measurements. Tubing (Bev-a-Line) was used to circulate air between the chamber and the IRGA by means of a pump which pulled air through the system at $2 \mathrm{~L} \mathrm{~min}^{-1}$ with $0.6-0.8 \mathrm{~L} \mathrm{~min}^{-1}$ diverted into the IRGA. A data logger (CR23X, Campbell Scientific, Inc.) recorded date, time, $\mathrm{CO}_{2}$ concentration, $\mathrm{H}_{2} \mathrm{O}$ concentration, air temperature, and PAR every second. All data was downloaded at the end of the field day. Measurements could only be taken during clear sunny days, as full light conditions (PAR preferably above $700 \mu \mathrm{mol} \mathrm{m} \mathrm{m}^{-2}$ ) were required to construct the light response curves and equipment could not get wet. Due to the frequency of cloudy days 
and substantial precipitation events, which saturated various sites by mid August, six days of measurement were completed during the 2008 field season. The sampling order among ecosystems was randomized daily so that diurnal variation in gas flux would not be confused with differences among plots.

\section{Opaque Chamber System}

Opaque static chambers with volumes of $0.0219 \mathrm{~m}^{3}$ were used to measure $\mathrm{CO}_{2}$ efflux and $\mathrm{CH}_{4}$ flux. Opaque covers on the chambers eliminated $\mathrm{CO}_{2}$ fixation by plants inside the chamber while measurements were made. At $0,5,10,15$ and 20 min after the chamber was sealed to the sampling collar, air within the chamber was mixed by manually pumping a $60 \mathrm{ml}$ syringe attached to the chamber with Bev-a-Line tubing and a 3-way stopcock. After mixing, $24 \mathrm{ml}$ of air was sampled from within the chamber and stored in a pre-evacuated exetainer (Labco) vial covered with silicone and rubber septum, for transport to Carleton University Biometeorology laboratory where $\mathrm{CO}_{2}$ and $\mathrm{CH}_{4}$ concentrations were obtained with a gas chromatograph (CP 3800, Varian, CA, USA) equipped with a flame-ionization detector (FID) and methanizer operated at $300^{\circ} \mathrm{C}$ and $350^{\circ} \mathrm{C}$, respectively using a He carrier gas at $30 \mathrm{ml} \mathrm{min}^{-1}$. Gas separation was obtained using a Haysep N 80/100 pre-column $(0.32 \mathrm{~cm}$ diam. $x 50 \mathrm{~cm}$ length $)$ and Poropak QS $80 / 100$ mesh analytical columns $(0.32 \mathrm{~cm}$ diam. $\times 200 \mathrm{~cm}$ length $)$ in column oven maintained at $50^{\circ} \mathrm{C}$. At least 3 replicates of five standards ranging from 439.2 and $15212.6 \mathrm{ppm} \mathrm{CO}_{2}$ and 1.08 and $19.94 \mathrm{ppm} \mathrm{CH}_{4}$ and $\mathrm{He}$ blanks were included in every gas sampling event to maintain quality control and establish the linear relationship between chromatogram area and gas concentrations. 
Sampling during the daytime occurred three to four times per week during the field season, for a total of 19 sets of measurements at all sites. The sampling order among ecosystems was randomized so that diurnal variation in gas flux would not be confused with differences among plots. Additionally, diurnal changes in $\mathrm{CO}_{2}$ and $\mathrm{CH}_{4}$ flux at the fen site were examined on three separate days by taking flux measurements at all 4 tussock collars and all 4 hollow collars sequentially at two hour increments from 8:00 to 16:00.

\section{Flux Calculation}

The flux of $\mathrm{CO}_{2}$ and $\mathrm{CH}_{4}$ was calculated using Equation 2.1, as the linear rate of change in gas species mixing ratio $(x)$, where flux is in units of $\mu \mathrm{mol} \mathrm{m}^{-2} \mathrm{~s}^{-1}, 8.314 \mathrm{~J} \mathrm{~K}^{-1}$ mol $^{-1}$ is the gas constant $(R), P$ is barometric pressure in $\mathrm{Pa}, T$ is air temperature in Kelvin and chamber volume $(V)$ and area $(A)$ are $\mathrm{m}^{3}$ and $\mathrm{m}^{2}$ respectively. The rate of change in concentration over time was computed from the 5 concentrations sampled over the 20 minute period and from the $1 \mathrm{~s}$ samples over a 2 minute period for the static opaque chamber effluxes and NEE measurements respectively. Positive fluxes indicate a loss of $\mathrm{CO}_{2}$ or $\mathrm{CH}_{4}$ from the ecosystem while negative fluxes indicate uptake by the ecosystem.

$$
F=\frac{V}{A} \frac{P}{R T} \frac{d x}{d t}
$$

\section{Environmental Measurements}

Several environmental variables were measured concurrently with both chamber measurements at locations outside the perimeter of each collar within the vegetation 
community plots. Soil temperatures at 3,6 and $9 \mathrm{~cm}$ depths were measured by manually inserting three themister probes (TD32, Omega, Stanford, CT, USA). Soil volumetric water content (VWC) $\left(\mathrm{m}^{3} \mathrm{~m}^{-3}\right)$ was recorded by vertically inserting a $20 \mathrm{~cm}$ probe from the soil surface (Hydrosense, Campbell Scientific Inc., Logan, UT, USA). VWC values were not calibrated to the specific soils and as a result provide a better idea of relative differences in VWC through time and over space than absolute VWC. Subsurface soil temperatures were measured with copper-constantan thermocouples at depths of 5, 10, $20,40,60 \mathrm{~cm}$ at the heath and shrub sites and at 5 and $10 \mathrm{~cm}$ below the surface at the sedge and fen tussock sites. At the sedge and fen hollow sites, soil temperatures were measured at $0,10,20,30,40,50$ and $60 \mathrm{~cm}$ from the surface where these sensors were added as the active layer deepened through the growing season.

Vegetation was monitored using the point frame method within the collars at three periods throughout the growing season. A frame with a $4 \times 4 \mathrm{~cm}$ grid was suspended over each collar and 38 pin drops were made within the collar at the intersection of grid lines within the collar. For each pin drop the species and the number of times live green vegetation was touched was recorded. Collar leaf area index (LAI), the projected leaf area per unit ground area, was calculated by dividing the number of vegetation "hits" by the total number of pin drops. In addition, vegetation was measured at the fen site by recording the height of all green (i.e. photosynthesizing) sedge leaves within a small 60 $\mathrm{cm}^{2}$ area (as sedges are the dominant vegetation at the site). One-sided LAI was calculated by multiplying the sum of all the leaf heights by the average leaf width ( 0.1 
$\mathrm{cm}$ ). Typical species of this site can have leaf widths from $<0.1 \mathrm{~cm}$ to $0.4 \mathrm{~cm}$ (Johnson, 1987). We used $0.1 \mathrm{~cm}$ to be more conservative since these larger widths are far rarer.

Vascular biomass ( $\mathrm{g}$ live biomass collar ${ }^{-1}$ ) for each collar was determined by clipping and drying vegetation within collars at the time of peak biomass (beginning of August, 2009). We clipped in the 2009 field season in order to enable sampling into late August 2008 at which point, various species were in the process of senescing. Samples were oven dried a minimum of 24 hours at $80^{\circ} \mathrm{C}$ and then weighed.

Thaw depth was recorded weekly by recording the maximum depth a steel rod could be inserted into the soil to the ice surface. Soil texture was determined using a sedimentation technique (Kemper \& Rosenau, 1986). Mineral soil samples were taken from 3 profiles at each site. At the dry sites samples were taken at depths of 10,30 and 60 $\mathrm{cm}$, while at the wet sites samples were taken below the peat layer. Half hourly records of precipitation (tipping bucket rain gauge, model TE525m, Texas Electronics, Dallas, TX, USA), photosynthetically active radiation (PAR) (quantum sensor, model LI-190SA, LI-COR), air temperature (model HMP45C, Vaisala Oyj, Helsinki, Finland) and atmospheric pressure (barometer, model PTB101B, Vaisala Oyj, Helsinki, Finland) were all obtained from a nearby meteorological tower (for more details see Lafleur \& Humphreys, 2008).

\subsubsection{Light-Temperature Response}

The relationship between NEE, PAR and T was described by Equation 2.2 (Bubier et al., 2003; Lafleur \& Humphreys, 2008). 


$$
N E E=\frac{G P_{\max } \alpha P A R}{\alpha P A R+G P_{\max }}+R_{10} Q_{10}^{\frac{r-10}{10}}
$$

The first term on the right hand side of the equation is based on a rectangular hyperbolic relationship between NEE $\left(\mu \mathrm{mol} \mathrm{m} \mathrm{s}^{-2}\right)$ and PAR $\left(\mu \mathrm{mol} \mathrm{m} \mathrm{m}^{-2}\right)$. The two parameters obtained are $\alpha$, the effective quantum yield (sensitivity of NEE to a change in light $\mathrm{mol} \mathrm{CO}_{2} \mathrm{~mol}^{-1}$ photons) and $\mathrm{GP}_{\max }$, the maximum photosynthetic uptake of $\mathrm{CO}_{2}$ at saturating light ( $\mu \mathrm{mol} \mathrm{m} \mathrm{m}^{-2} \mathrm{~s}^{-1}$ ). The second term is based on the exponential relationship between ecosystem respiration (ER) $\left(\mu \mathrm{mol} \mathrm{m} \mathrm{m}^{-2}\right)$ and air temperature $\left({ }^{\circ} \mathrm{C}\right)$ within the chamber. The parameters obtained are $R_{10}$, ecosystem respiration at a reference temperature $\left(\mathrm{T}_{\mathrm{ref}}\right)$ of $10^{\circ} \mathrm{C}\left(\mu \mathrm{mol} \mathrm{m} \mathrm{m}^{-2} \mathrm{~s}^{-1}\right)$, given a $\mathrm{Q}_{10}$ value of 1.63 (rate of increase in ER for a $10^{\circ} \mathrm{C}$ increase in temperature). The $Q_{10}$ value of 1.63 was the average $Q_{10}$ obtained for all the sites. This value is lower than the common estimate of 2 , however a $Q_{10}$ value of 2 appears to overestimate the combined below and above-ground respiration likely due to a mismatch between near-surface air temperature within the chamber and soil temperature at the major areas of $\mathrm{CO}_{2}$ production in a soil profile underlain by permafrost.

\subsubsection{Modeling the Carbon Balance and Radiative Forcing Potential of Each Ecosystem Type}

The data collected during the growing season was used to estimate the July and August carbon balance and radiative forcing potential from $\mathrm{CO}_{2}$ and $\mathrm{CH}_{4}$ flux estimates for each of the six ecosystem types. To estimate $\mathrm{CO}_{2}$ exchange, Equation 2.2 was used in combination with half hour averages of PAR and air temperature. The tower air 
temperature values were adjusted to reflect near surface temperatures using a relationship developed between chamber air temperature taken during chamber measurements and corresponding tower air temperature. To roughly estimate July-August $\mathrm{CH}_{4}$ exchange, the average $\mathrm{CH}_{4}$ efflux measured during this period was simply summed over the two month period as $\mathrm{CH}_{4}$ exchange was found to have relatively small seasonal and diurnal variation. The global warming potential (GWP) methodology outlined by the IPCC (2007) is used to determine the relative forcing potential of each vegetation community. Emission of $\mathrm{CH}_{4}$ is calculated as 72 and 21 times the GWP of $\mathrm{CO}_{2}$ for the 20 and 100 year time horizon respectively and units are given in $\mathrm{CO}_{2}$ equivalents (IPCC, 2007).

\subsubsection{Statistical Analysis}

JMP (J.M.P.7 Statistical Analysis Software, 2007) was used for all statistical analyses. One-way analysis of variance (ANOVA) was used to test for significant differences between means of soil temperature, VWC and field measurements of NEE and its component fluxes among vegetation communities. Repeated-measure analysis of variance (RM ANOVA) was used to investigate the influence of vegetation community (between subjects) and time (within subjects) on $\mathrm{CO}_{2}$ and $\mathrm{CH}_{4}$ fluxes. Wilks' Lambda was used as the test statistic for RM ANOVAs. Post-hoc multiple comparisons were analyzed using the Tukey's Honest Significant Difference test (HSD). Spearman's correlation coefficient was used to test for significant relationships between fluxes and environmental variables. Methane fluxes were log transformed to meet normality and heterogeneity of variance assumptions in statistical analysis. 


\subsection{Results}

\subsubsection{Site Characteristics}

Soil and vegetation characteristics of the six vegetation communities are listed in Table 2.1. The two drier sites, heath and shrub had shallow organic layers and coarser soil textures (sand and loamy sand respectively) in comparison to the wetter sites, sedge \& fen (tussock and hollow) which both had substantial peat accumulation. LAI using the point frame method was lowest at the sedge hollow site and highest at the shrub site. As sedge vegetation grows largely vertically, LAI using the leaf count method at the fen site was used for comparison. This method shows higher LAI at the fen site as compared to the point frame method. The uncertainty of this method is likely to be high, as the average leaf width was not measured and instead the value of $0.1 \mathrm{~cm}$ was used as a best estimate. Moss cover was higher at the wetter sites with the highest moss cover at the fen tussocks. Biomass was significantly higher at the shrub site than the 5 other sites. There was a large difference in biomass at the sedge site between tussocks and hollows, while this disparity was not seen at the fen. The dominant vascular species at the dry heath and shrub sites were small shrubs such as Ledum Decumbens (Ait.), Vaccinium vitis-idaea (L.) and Betula glandulosa (Michx.), while the wet sites were dominated by grasses, Carex spp, Eriophorum spp. (L.) (Table 2.1).

Mean soil temperature at $3 \mathrm{~cm}$ depth was significantly higher at the shrub and sedge tussock sites, presumably due to the dry organic surface layers with low thermal conductivity (Table 2.2). The differences in soil temperature among sites were smaller at 
Table 2.1: Soil and vegetation characteristics of the six tundra environments at Daring Lake, N.W.T during July and August, 2008. Values in brackets indicate \pm 1 standard error of the mean. Texture and organic matter content were not assessed separately for tussocks and hollows. Values for each variable that do not share superscript letters in common indicate significant differences between ecosystems (Tukey's HSD, $\mathrm{p}<0.05$ ).

\begin{tabular}{|c|c|c|c|c|c|c|}
\hline & Heath & Shrub & $\begin{array}{l}\text { Sedge } \\
\text { Tussock }\end{array}$ & $\begin{array}{l}\text { Sedge } \\
\text { Hollow }\end{array}$ & $\begin{array}{l}\text { Fen } \\
\text { Tussock }\end{array}$ & $\begin{array}{l}\text { Fen } \\
\text { Hollow }\end{array}$ \\
\hline Soil Texture & Sand & Loamy Sand & \multicolumn{2}{|c|}{ Peat over Loamy Sand } & \multicolumn{2}{|c|}{ Peat over Silt Loam } \\
\hline $\begin{array}{l}\text { Depth of } \\
\text { organic layer } \\
\text { (cm) }\end{array}$ & $2-5$ & $0-10$ & $40-60^{*}$ & $20-40$ & $50-60 *$ & $40-50$ \\
\hline $\begin{array}{l}\text { Average } \\
\text { Organic Matter } \\
\text { Content } 0-25 \\
\text { cm depth } \\
\left(\mathrm{kg} \mathrm{m}^{-2}\right)\end{array}$ & $8.45(0.97)$ & $12.86(2.66)$ & $23.54(4.27)$ & & $21.56(1.26)$ & \\
\hline $\begin{array}{l}\text { Average Leaf } \\
\text { Area Index } \\
\text { (live leaf area } \\
\text { per unit } \\
\text { ground) } \\
\left(\mathrm{m}^{2} \mathrm{~m}^{-2}\right) \delta\end{array}$ & 0.95 & 1.04 & 0.65 & 0.365 & 0.536 & 0.375 \\
\hline $\begin{array}{l}\text { Average Leaf } \\
\text { Area Index } \\
\text { (live leaf area } \\
\text { per unit } \\
\text { ground) } \\
\left(\mathrm{m}^{2} \mathrm{~m}^{-2}\right) \mathrm{l}\end{array}$ & & . & & . & 0.64 & \\
\hline $\begin{array}{l}\text { Moss Cover } \\
\text { ( } \% \text { cover) }\end{array}$ & 0.2 & 27.6 & 25.0 & 82.9 & 96.9 & 94.7 \\
\hline $\begin{array}{l}\text { Vascular Cover } \\
\text { (\% cover) }\end{array}$ & 43.4 & 51.3 & 34.2 & 30.3 & 31.8 & 53.7 \\
\hline $\begin{array}{l}\text { Live Vascular } \\
\text { Plant Biomass } \\
\left(\mathrm{g} \mathrm{collar}^{-1}\right)^{+}\end{array}$ & $12.97(2.23)^{\mathrm{a}}$ & $28.83(4.65)^{b}$ & $10.60(1.68)^{a}$ & $2.63(0.35)^{\mathrm{a}}$ & $4.30(0.81)^{\mathrm{a}}$ & $4.18(0.82)^{a}$ \\
\hline $\begin{array}{l}\text { Dominant } \\
\text { Vascular } \\
\text { Species }\end{array}$ & $\begin{array}{l}\text { L. decumbens } \\
\text { (Ait.) } \\
\text { V. vitis-idaea } \\
\text { (L.) }\end{array}$ & $\begin{array}{l}\text { B. glandulosa } \\
\text { (Michx.) } \\
\text { L. decumbens (Ait.) } \\
\text { V. vitis-idaea (L.) }\end{array}$ & $\begin{array}{l}\text { Carex spp } \\
\text { Eriophorum } \\
\text { spp. (L.) } \\
\text { L. decumbens } \\
\text { (Ait.) }\end{array}$ & $\begin{array}{l}\text { Carex spp } \\
\text { Eriophorum } \\
\text { spp. }(L .)\end{array}$ & $\begin{array}{l}\text { Carex spp } \\
\text { Eriophorum } \\
\text { spp. (L.) }\end{array}$ & $\begin{array}{l}\text { Carex spp } \\
\text { Eriophorum } \\
\text { spp. }(L .)\end{array}$ \\
\hline
\end{tabular}

* The depth of organic matter at the sedge and fen tussocks is an estimate given the depth at the hollows plus an average 20 and $10 \mathrm{~cm}$ respectively for height of tussocks.

$\delta$ Leaf Area Index with the point frame method.

T Leaf Area Index with the leaf count method.

+ Biomass was collected in early August 2009. 
Table 2.2: Environmental characteristics of the six tundra environments at Daring Lake, N.W.T. Values are mean of the 4 collar locations during July and August 2008 (values in brackets indicate \pm 1 standard error of the mean). Values for each variable that do not share superscript letters in common indicate significant differences between ecosystems (Tukey's HSD, p<0.05). VWC, volumetric water content.

\begin{tabular}{lllllll}
\hline & Heath & Shrub & $\begin{array}{l}\text { Sedge } \\
\text { Tussock }\end{array}$ & $\begin{array}{l}\text { Sedge } \\
\text { Hollow }\end{array}$ & $\begin{array}{l}\text { Fen } \\
\text { Tussock }\end{array}$ & Fen Hollow \\
\hline $\begin{array}{l}\text { Mean soil temperature } \\
\text { at } 3 \mathrm{~cm}\left({ }^{\circ} \mathrm{C}\right)\end{array}$ & $15.0(0.6)^{\mathrm{c}}$ & $19.6(0.6)^{\mathrm{a}}$ & $17.5(0.6)^{\mathrm{ab}}$ & $14.6(0.6)^{\mathrm{c}}$ & $15.4(0.6)^{\mathrm{bc}}$ & $14.9(0.6)^{\mathrm{c}}$ \\
$\begin{array}{l}\text { Mean soil temperature } \\
\text { at } 6 \mathrm{~cm}\left({ }^{\circ} \mathrm{C}\right)\end{array}$ & $10.5(0.4)^{\mathrm{b}}$ & $12.6(0.4)^{\mathrm{a}}$ & $12.7(0.4)^{\mathrm{a}}$ & $10.3(0.4)^{\mathrm{b}}$ & $12.6(0.4)^{\mathrm{a}}$ & $12.0(0.4)^{\mathrm{a}}$ \\
$\begin{array}{l}\text { Mean soil temperature } \\
\text { at } 9 \mathrm{~cm}\left({ }^{\circ} \mathrm{C}\right)\end{array}$ & $9.3(0.3)^{\mathrm{bc}}$ & $9.9(0.3)^{\mathrm{ab}}$ & $10.2(0.3)^{\mathrm{ab}}$ & $8.4(0.3)^{\mathrm{c}}$ & $11.1(0.3)^{\mathrm{a}}$ & $10.7(0.3)^{\mathrm{a}}$ \\
$\begin{array}{l}\text { Maximum thaw depth } \\
(\mathrm{cm})\end{array}$ & 105.0 & 97.8 & 77.8 & 69.4 & 73.1 & 63.1 \\
$\begin{array}{l}\text { Mean VWC }\left(\mathrm{m}^{3} \mathrm{~m}^{-3}\right) \\
(0-20 \mathrm{~cm})\end{array}$ & $24.8(1.5)^{\mathrm{a}}$ & $15.3(1.5)^{\mathrm{b}}$ & $36.5(1.5)^{\mathrm{c}}$ & $75.6(1.5)^{\mathrm{d}}$ & $63.8(1.4)^{\mathrm{e}}$ & $88.6(1.4)^{\mathrm{f}}$ \\
$\begin{array}{l}\text { * Maximum thaw depth at the fen tussock is an estimate given the depth at the fen hollows plus an average } 10 \mathrm{~cm} \\
\text { height of fen tussocks }\end{array}$ & & & & & &
\end{tabular}


6 and $9 \mathrm{~cm}$ below the surface although heath and sedge hollow sites had significantly lower temperatures at $6 \mathrm{~cm}$. Sedge tussocks had significantly higher temperatures then sedge hollows at depths of 3,6 and $9 \mathrm{~cm}$, while there was no significant difference between the temperature of fen tussocks and hollows at any depth. Maximum thaw depths were 34 to $42 \mathrm{~cm}$ deeper at the dry heath and shrub sites compared to the wetter sedge and fen sites. Thaw depth was least at the fen site, an area with a substantial peat layer and water logging resulting in slow warming due to the high heat capacity of this soil. Each site had significantly different mean VWC with the fen and sedge hollows having the highest values of 88.6 and $75.6 \%$ respectively and the drier heath and shrub sites having the lower values of 24.8 and $15.3 \%$ respectively (Table 2.2 ).

After solar radiation peaked at summer solstice (DOY 172), PAR decreased throughout the season (Figure 2.3). Mean daily air and soil temperature fluctuated during the field season with peak maximum daily temperatures occurring mid July to mid August ( 198-223) and then decreasing thereafter (Figure $2.3 \&$ Figure 2.4$)$. Daily atmospheric pressure fluctuated throughout the growing season (Figure 2.3). The active layer depth at all sites gradually increased with the greatest rates of increase and the deepest active layers occurring at the heath and shrub sites (Figure 2.4).

During the summer of 2008 large precipitation events increased in occurrence from August $5^{\text {th }}$ (DOY 218) to the end of the study period (Figure 2.3) resulting in increasing VWC at all sites (Figure 2.4). The water table at the fen site decreased below the moss surface though July until August $5^{\text {th }}$ (DOY 218) and then rose substantially thereafter to $10.7 \mathrm{~cm}$ above to moss surface by August $26^{\text {th }}$ (DOY 239) (Figure 2.5). 
Lafleur \& Humphreys (2008) observed the tundra to be wettest immediately after snowmelt and gradually drying throughout the summer. This trend can be seen in Figure 2.4 where the soil water content shows a decreasing trend to the beginning of August (DOY 194 - 223). The large accumulation of water from precipitation events reverses this trend for the second half of the 2008 field season (Figure 2.4). In comparison to the historical precipitation record at the site (1997-2005) for the observational period May $15^{\text {th }}$ (DOY 135) to August $31^{\text {st }}$ (DOY 243), precipitation in 2008 was $184.6 \mathrm{~mm}$, which is higher than average (103.7 mm) (Lafleur \& Humphreys, 2008).

Soil VWC varied among sites (Figure 2.4). The shrub site had very low VWC throughout the study period while values were slightly greater at the heath site (Table 2.2). The sedge and fen hollows had the highest VWC, followed by the fen tussock site and then the sedge tussock site. Since this study began several weeks after spring snowmelt (DOY 142, based on reflected radiation data at nearby meteorological towers), it is likely VWC could have been greater earlier in the season, particularly at the upland sites as peak soil moisture values have been recorded at this time in previous years (Nobrega \& Grogan, 2008; Lafleur \& Humphreys, 2008). 

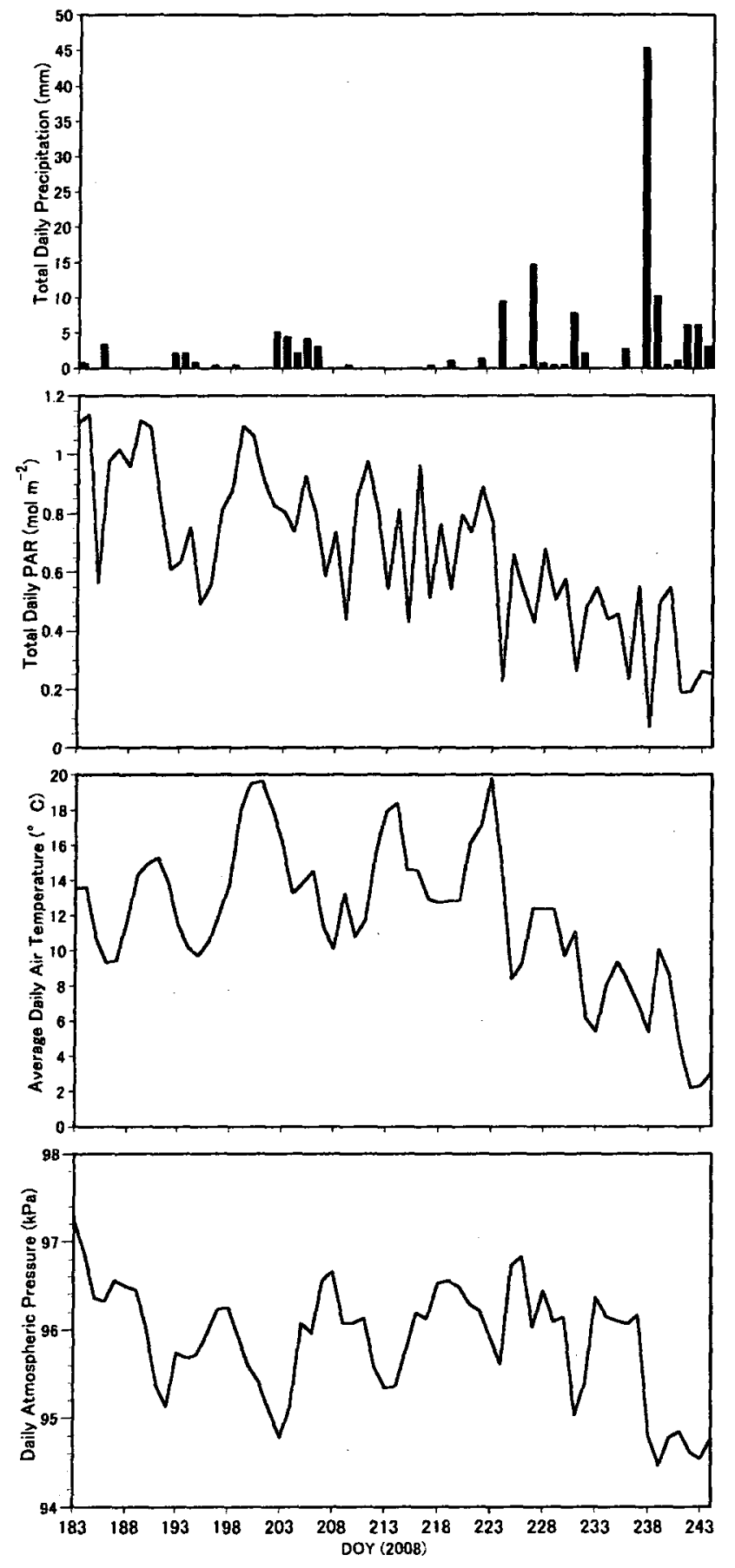

Figure 2.3: Total daily precipitation $(\mathrm{mm})$, total daily photosynthetically active radiation (PAR) $(\mathrm{mol} \mathrm{m}-2)$, average daily temperature $\left({ }^{\circ} \mathrm{C}\right)$ at $1.5 \mathrm{~m}$ from ground, and average daily atmospheric pressure $(\mathrm{kPa})$ at Daring Lake, N.W.T from July $1^{\text {st }}$ to August $31^{\text {st }}$, 2008. 

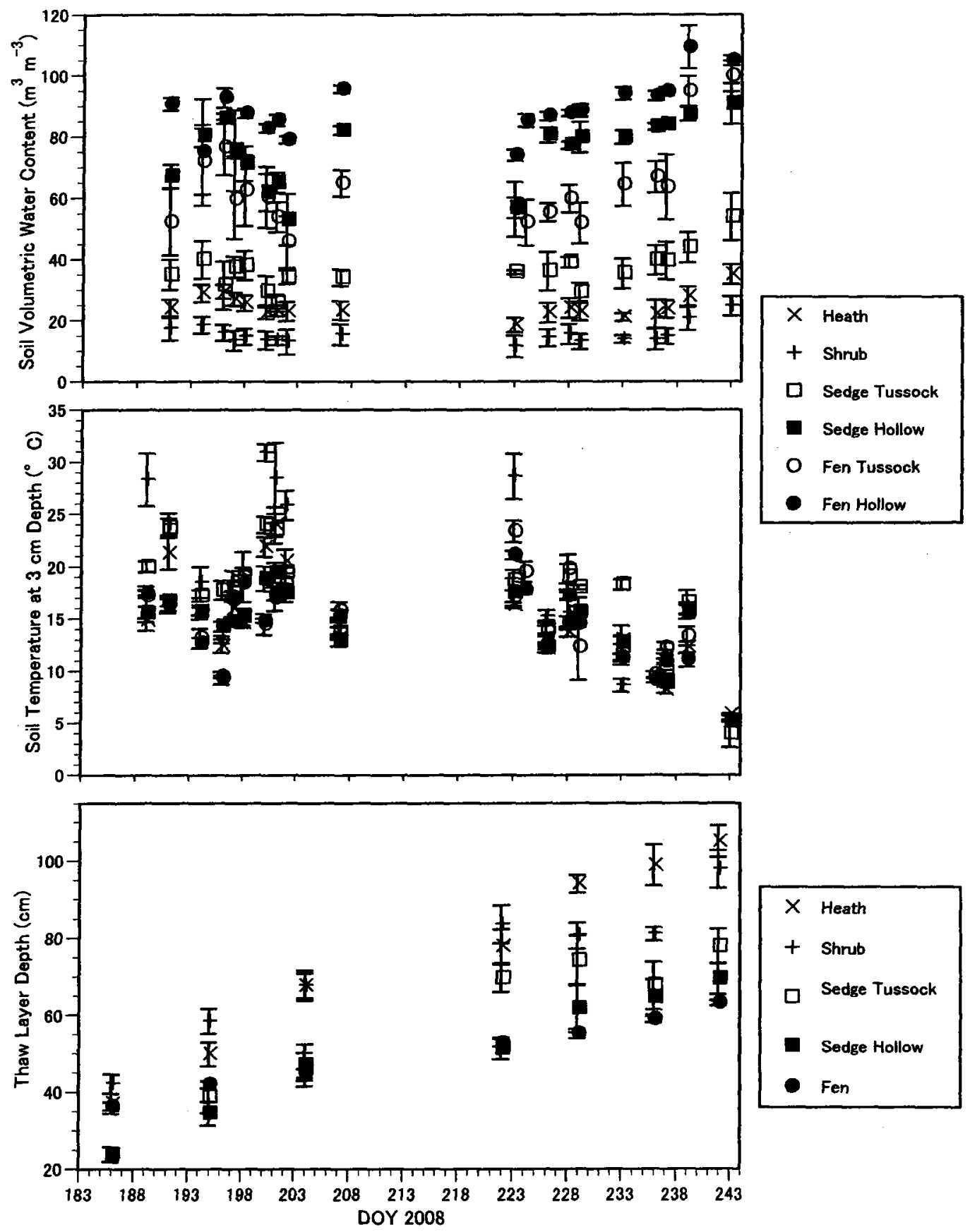

Figure 2.4: Soil volumetric water content from $0-20 \mathrm{~cm}$ depth $\left(\mathrm{m}^{3} \mathrm{~m}^{-3}\right)$, soil temperature at $3 \mathrm{~cm}$ depth and thaw layer depth $(\mathrm{cm})$ during the July \& August field season at the six vegetation communities. The thaw layer depth was not separated for tussocks and hollow at the fen site. 


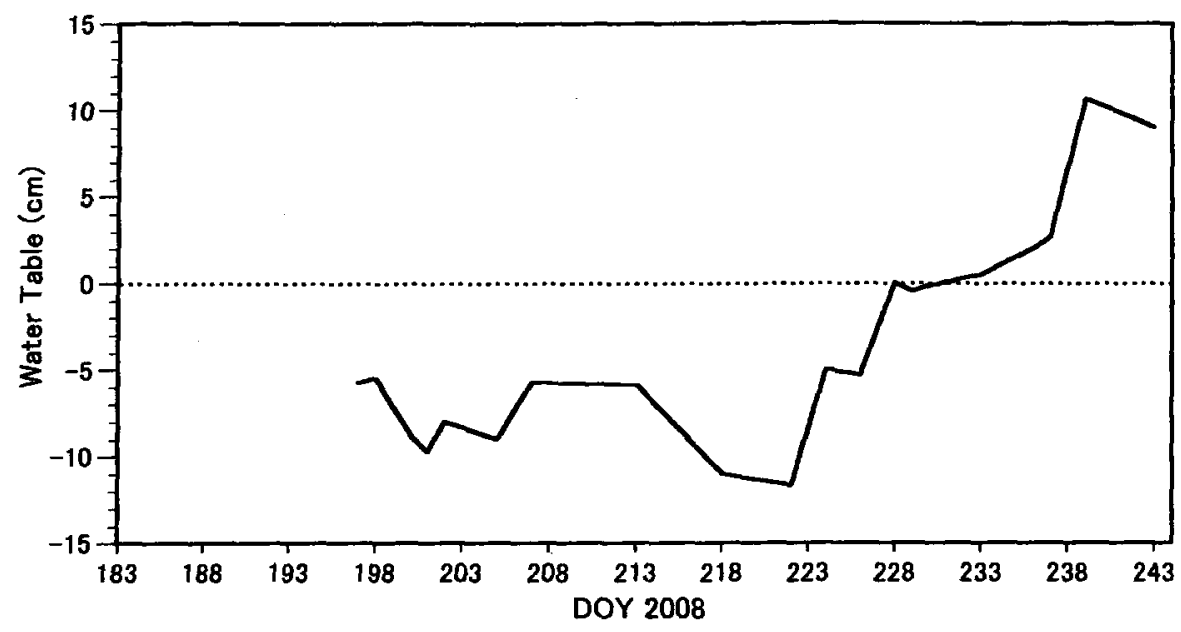

Figure 2.5: Water table in reference to moss surface at fen site from July $15^{\text {th }}$ to August $30^{\text {th }}, 2008$. 
These results show similarities and differences in abiotic and biotic variables among and between vegetation community plots during the 2008 field season. All sites showed seasonal declines in soil temperatures and increases in active layer depth. They all also showed an initial decrease in VWC in July and then an increase in August due to substantial precipitation events. The heath and shrub plots, with shallow soil organic layers and drier conditions, had less moss cover and deeper active layers. The sedge and fen tussock and hollow plots had significant peat accumulation, wetter conditions, greater moss cover and shallower active layers. Additionally, the sedge and fen plots display heterogeneity in environmental variables due to topography. Within these waterlogged areas, tussocks were raised zones of loose peat situated above the water table for most of the study period creating zones of aeration within these wet areas. At the sedge plots, biomass was larger for the tussocks than the hollows (Table 2.1) and tussocks were qualitatively observed to be larger in height and width than the fen tussocks with a tendency to be warmer and drier microenvironments (Table 2.2). Tussocks at the sedge plots had a low percent moss cover and species such as Ledum Decumbens (Ait.) could flourish. Typically, sedges such as Eriophorum spp. (L.) are found to dominate tussocks in early stages of development but gradually become invaded by other plants as tussocks age (Leadley \& Reynolds, 1992). This suggests that tussocks in the sedge plot area are possibly at a different stage of succession than those at the fen.

\subsubsection{Net Ecosystem Exchange of $\mathrm{CO}_{2}$ (NEE)}

Field measurements of NEE and component fluxes for the six vegetation communities are found in Table 2.3. NEEmax and GEPmax were not significantly 
different among communities $\left(\mathrm{F}_{5,59}=0.83 \mathrm{p}=0.54\right.$ and $\mathrm{F}_{5,59}=0.77 \mathrm{p}=0.58$ respectively) while there was a significant difference in $\mathrm{ER}$ among communities $\left(\mathrm{F}_{5,59}=\right.$ $5.57 \mathrm{p}=0.0003$ ). Average ER was significantly higher at the shrub site compared to the wet sedge hollow, fen tussock and fen hollow sites. There was no significant difference between the dry heath and shrub site, and no significant difference among all the wet sites, sedge and fen, tussock and hollows. NEEmax was greatest at the fen tussock and sedge and fen hollow communities due to lower ER and moderate GEPmax. NEEmax was lowest at the heath site due to lower GEPmax and moderate ER. The shrub site also had fairly low NEEmax despite the highest GEPmax due to relatively high ER.

Additionally, as ER was measured both with the NEE chamber system and opaque static chambers, the difference between $\mathrm{CO}_{2}$ efflux from the two techniques examined via a pair wise t-test, and found no significant difference $(p=0.98)$. This supports the validity of the ER measurements for all six vegetation communities. As measurement of NEE at the six vegetation communities could not occur simultaneously, a NEE model (Equation 2.2) was parameterized to compare NEE and its component fluxes among vegetation communities without the confounding issues of short-term variations in weather or time of day influencing NEE. 
Table 2.3: Field measurements of NEE exchange and component fluxes for the six vegetation communities Values are mean \pm 1 standard error of the mean. NEE, net ecosystem exchange of $\mathrm{CO}_{2}$; NEEmax, average NEE for PAR greater than $1000 \mu \mathrm{mol} \mathrm{m}$ ${ }^{2} \mathrm{~s}^{-1}$; ER, ecosystem respiration of $\mathrm{CO}_{2} ;$ GEPmax, gross ecosystem production for PAR greater than $1000 \mu \mathrm{mol} \mathrm{m} \mathrm{m}^{-2} \mathrm{~s}^{-1}$. Negative values indicate carbon uptake and positive values indicate carbon loss by the ecosystem. Values for each variable that do not share superscript letters in common indicate significant differences between communities (Tukey's HSD, $\mathrm{p}<0.05$ ).

\begin{tabular}{lllllll}
\hline & Heath & Shrub & $\begin{array}{l}\text { Sedge } \\
\text { Tussock }\end{array}$ & $\begin{array}{l}\text { Sedge } \\
\text { Hollow }\end{array}$ & $\begin{array}{l}\text { Fen } \\
\text { Tussock }\end{array}$ & $\begin{array}{l}\text { Fen } \\
\text { Hollow }\end{array}$ \\
\hline $\begin{array}{l}\text { NEEmax } \\
\left(\mu \mathrm{mol} \mathrm{m} \mathrm{m}^{-2} \mathrm{~s}^{-1}\right)\end{array}$ & $-0.73(0.27)^{\mathrm{a}}$ & $-1.01(0.36)^{\mathrm{a}}$ & $-1.00(0.24)^{\mathrm{a}}$ & $-1.40(0.12)^{\mathrm{a}}$ & $-1.57(0.23)^{\mathrm{a}}$ & $-1.30(0.14)^{\mathrm{a}}$ \\
$\begin{array}{l}\mathrm{ER} \\
\left(\mu \mathrm{mol} \mathrm{m}^{-2} \mathrm{~s}^{-1}\right)\end{array}$ & $1.57(0.14)^{\mathrm{ab}}$ & $2.26(0.19)^{\mathrm{a}}$ & $1.71(0.14)^{\mathrm{ab}}$ & $1.32(0.09)^{\mathrm{b}}$ & $1.29(0.15)^{\mathrm{b}}$ & $1.38(0.15)^{\mathrm{b}}$ \\
$\begin{array}{l}\mathrm{GEPmax} \\
\left(\mu \mathrm{mol} \mathrm{m}^{-2} \mathrm{~s}^{-1}\right)\end{array}$ & $-2.30(0.20)^{\mathrm{a}}$ & $-3.28(0.43)^{\mathrm{a}}$ & $-2.72(0.31)^{\mathrm{a}}$ & $-2.71(0.14)^{\mathrm{a}}$ & $-2.86(0.31)^{\mathrm{a}}$ & $-2.68(0.16)^{\mathrm{a}}$ \\
\hline
\end{tabular}


The response of NEE to PAR and T was assessed with Equation 2.2 (Table 2.4 and Figure 2.6). There was a clear response of NEE to light at all sites. GPmax was greatest at the fen tussock and hollow sites and lowest at the sedge tussock and heath sites (Table 2.4). The initial slope of the curve, alpha ( $\alpha$ ) did not differ significantly among sites. In general $R_{10}$ was higher at the drier heath and shrub sites. These results suggest that at fen tussock and hollow sites and sedge hollow sites, biotic and abiotic conditions (water logging with high percent moss cover with sedges as a dominant vascular species) favoured high $\mathrm{CO}_{2}$ uptake rates and lower ER rates. The drier heath, shrub and sedge tussock sites had smaller $\mathrm{CO}_{2}$ uptake rates and higher rates of ER. The dry shrub site however had the highest biomass, contributing to the highest $\mathrm{CO}_{2}$ uptake rates among the drier sites, but also the highest ER rates of all the sites. 

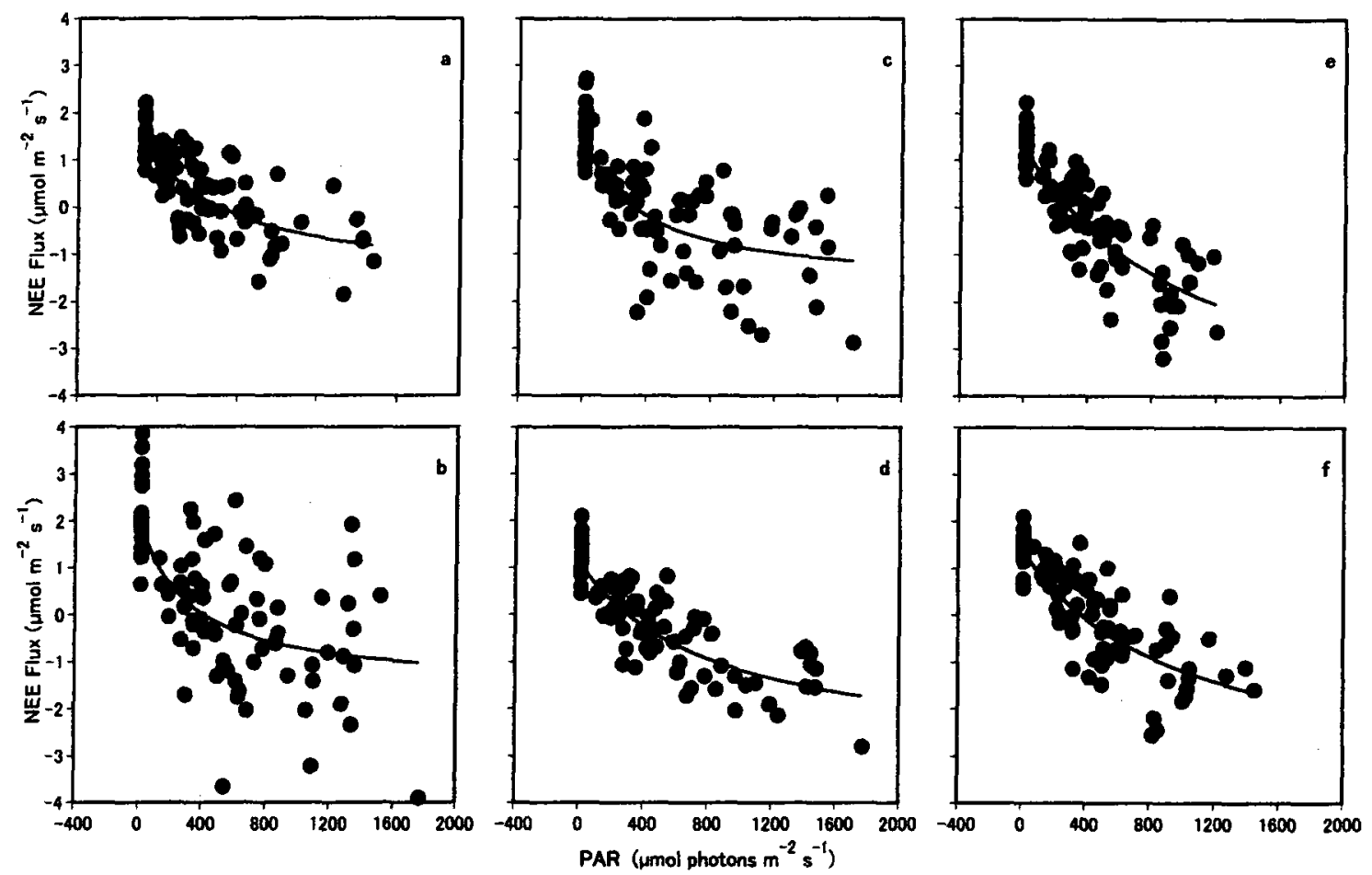

Figure 2.6: Relationships between photosynthetically active radiation (PAR) and net ecosystem exchange of $\mathrm{CO}_{2}(\mathrm{NEE})$ at sites a) heath, b) shrub c) sedge tussock, d) sedge hollow, e) fen tussock $f$ ) fen hollow. Curves (solid lines) correspond to Equation 2.2 with the parameters listed in Table 2.4 and the mean chamber air temperature recorded during measurements. Negative values indicate net ecosystem carbon gain and positive values indicate net carbon loss by the ecosystem. 


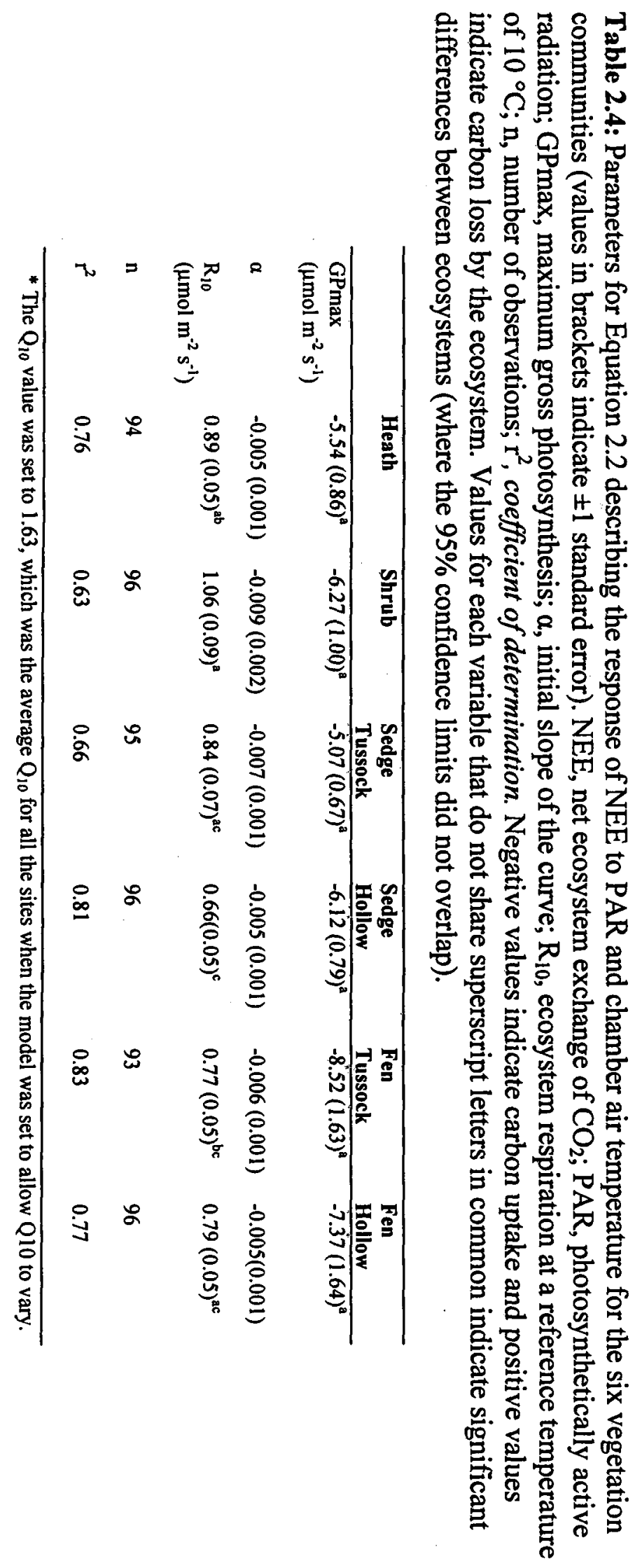


Modeled light and temperature response curves generally had high $\mathrm{r}^{2}$ values (Table 2.4), however due to the large variability in NEE and lower $r^{2}$ at the shrub site (Figure 2.6b and Table 2.4), this relationship was further investigated and additional heterogeneity was found within the four sampling locations at this community. Collars 1 and 2 were located within a large shrubby area extending at least $3 \mathrm{~m}$ around the collars and displayed greater $\mathrm{CO}_{2}$ uptake with increasing PAR (Figure 2.7a). Collars 3 and 4 located within areas where shrubs were found in isolated patches, had less $\mathrm{CO}_{2}$ uptake and were less sensitive to PAR (Figure 2.7b). GPmax for collars 1 and 2 were double the magnitude of collars 3 and 4 (Table 2.5).

There are two main hypotheses to explain the distinct heterogeneity within the shrub site. First, as the presence of the continuous shrubby areas indicates better growing conditions for shrub colonization one would presume that at high temperatures sites 1 and 2 coped better than sites 3 and 4 due to more favourable conditions in the continuous zone. Secondly, the biomass data collected in 2009 indicated considerable die-back in collars 3 and 4 where the $\%$ dead leaves was $5 \%$ and $3 \%$ in collars 1 and 2 vs. $31 \%$ and $38 \%$ in collars 3 and 4 , respectively. As the shrubs appear to have large root systems that extend laterally, the root systems likely were cut to some extent during collar installation. Therefore there is the possibility that collar locations 3 and 4 may have suffered more detrimental manipulation due to collar installation. This documents the difficulty of measuring fluxes using chamber techniques at these sites and the potential effects of altering carbon cycling dynamics in these shrub vegetation communities. 


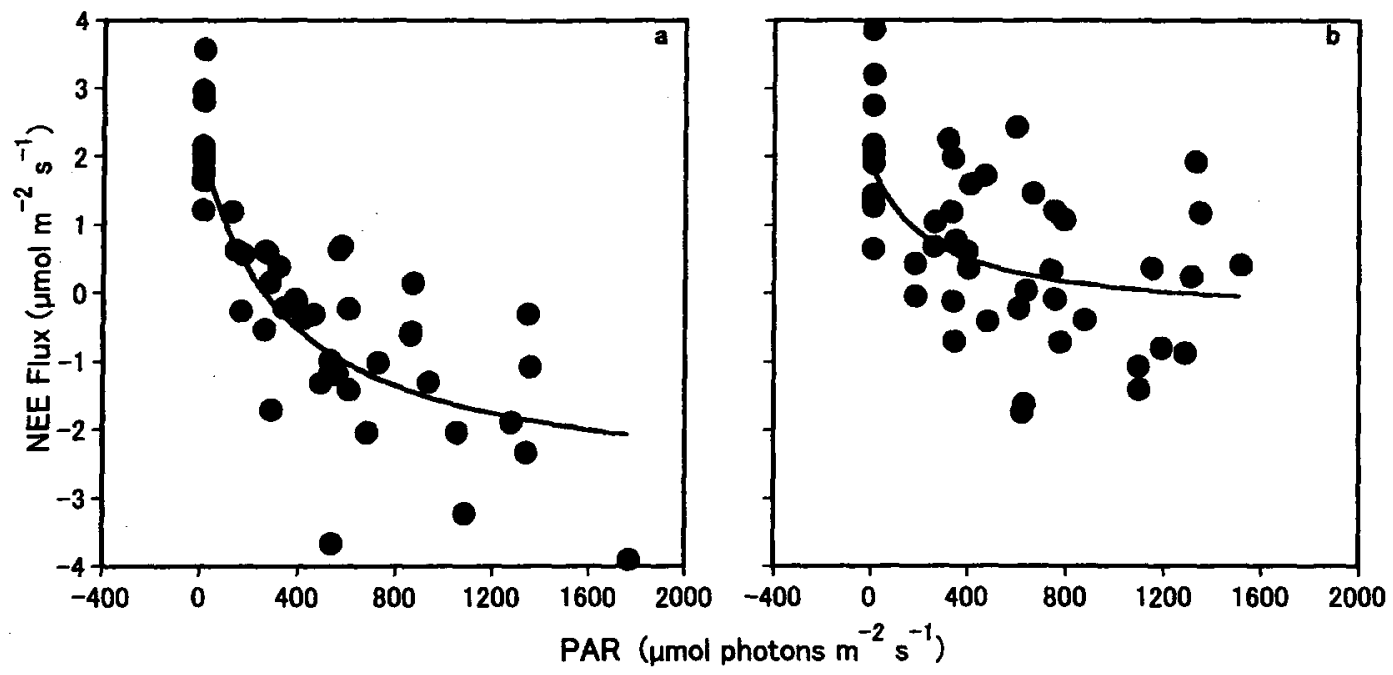

Figure 2.7: Relationships between photosynthetically active radiation (PAR) and net ecosystem exchange of $\mathrm{CO}_{2}$ (NEE) at sites a) shrub sites 1 and 2 , in continuous shrub zone b) shrub sites 3 and 4, separated from continuous shrub zone. Curves are fit based on Equation 2.2. Negative values indicate net ecosystem carbon gain and positive values indicate net carbon loss by the ecosystem. 
Table 2.5: Parameters for Equation 2.2 describing the response of NEE to PAR and $T$ for shrub site collars grouped by similar vegetation community characteristics (values in brackets indicate \pm 1 standard error of the mean). Symbols are described in Table 2.4. Negative values indicate carbon uptake and positive values indicate carbon loss by the ecosystem.

\begin{tabular}{lll}
\hline & Shrub 1 \& 2 & Shrub 3 \& 4 \\
\hline NEEmax $\left(\mu \mathrm{mol} \mathrm{m}^{-2} \mathrm{~s}^{-1}\right)$ & $-2.13(0.46)$ & $-0.03(0.42)$ \\
GPmax $\left(\mu \mathrm{mol} \mathrm{m} \mathrm{s}^{-2}\right)$ & $-8.39(1.14)$ & $-4.62(1.15)$ \\
$\alpha$ & $-0.011(0.002)$ & $-0.006(0.002)$ \\
$\mathrm{R}_{10}\left(\mu \mathrm{mol} \mathrm{m}^{-2} \mathrm{~s}^{-1}\right)$ & $1.13(0.01)$ & $1.01(0.01)$ \\
$\mathrm{n}$ & 48 & 48 \\
$\mathrm{r}^{2}$ & 0.83 & 0.63 \\
\hline
\end{tabular}


Direct field measurements of NEE, GEPmax and ER are a function of both the biotic and abiotic conditions within a particular vegetation community. Using the NEE model normalizes light and temperature conditions and allows for investigation into GEP and ER rates inherent to the six vegetation communities such that functional differences related to plant species and below ground microbial processes, for example, can be explored. Generally, there is good agreement between the two methods in the trends observed among vegetation communities. The direct field measurements indicate greatest to least GEPmax:

Shrub $>$ Fen Tussock $>$ Sedge Tussock $>$ Sedge Hollow $>$ Fen Hollow $>$ Heath. While the NEE model has sites with GPmax greatest to least:

Fen Tussock $>$ Fen Hollow $>$ Shrub $>$ Sedge Hollow $>$ Heath $>$ Sedge Tussock.

For the direct field measurements of ER, sites from greatest to least are: Shrub $>$ Sedge Tussock $>$ Heath $>$ Fen Hollow $>$ Sedge Hollow $>$ Fen Tussock. While for the NEE model results, the order of $R_{10}$ from greatest to least is: Shrub $>$ Heath $>$ Sedge Tussock $>$ Fen Hollow $>$ Fen Tussock $>$ Sedge Hollow . Both methods give higher rates of photosynthesis for the shrub and wet sites, and the lowest at the dry heath. Rates of ER are higher for the drier sites as compared to the wet sites for both methods as well. Field measurements show significantly higher rates of respiration at the shrub site presumably due to significant higher near surface temperatures (Table 2.2). The model gives respiration rates at $10^{\circ} \mathrm{C}$ and confirms that even when normalized for temperature, respiration is still highest at the shrub site and significantly different from the sedge hollow and fen tussock site but the magnitude of 
difference is not as great. The model also gives higher rates of GEP at the fen tussock and hollow sites rather than the shrub site as found in field measurements. One of the more noticeable discrepancies is for the fen hollow site with relatively low GEPmax ( $2^{\text {nd }}$ last) but relatively high GPmax ( $2^{\text {nd }}$ highest). Another difference is noted for the sedge tussock which has moderate GEPmax ( $3^{\text {rd }}$ highest) but the lowest GPmax. This highlights the variation in results from field measurements, which estimate GEP given the difference between NEE and ER, versus light response models studies which aim to best fit NEE data and supply model parameters.

\subsection{3. $\mathrm{CO}_{2}$ Efflux and $\mathrm{CH}_{4}$ Flux}

When measured using static opaque chambers, $\mathrm{CO}_{2}$ respiration was measured three times as often as it was measured with the NEE chamber system and again confirmed that $\mathrm{CO}_{2}$ efflux was significantly different among sites $\left(\mathrm{F}_{5,18}=3.16 ; \mathrm{p}=\right.$ 0.0321 ) using $\mathrm{RM}$ ANOVA. $\mathrm{CO}_{2}$ respiration was significantly higher at the shrub site than at all other sites (Figure 2.8b). Sedge tussock respiration was significantly lower than the shrub and fen hollow sites (Figure 2.8b). The maximum and minimum and mean $\mathrm{CO}_{2}$ efflux for each vegetation community can be seen in Table 2.6. RM ANOVA also found the interaction of vegetation community and time to be significant (Wilks $F_{85,14}=$ $2.44 ; p=0.0315)$ indicating that the temporal variation of $\mathrm{CO}_{2}$ efflux was not the same at all sites (Figure 2.9). As an additional note, the removal of the shrub site from the RM ANOVA resulted in no significant difference among sites $\left(F_{4,15}=1.05 p=0.4159\right)$ or in the interaction of vegetation community and time. This suggests that only at the shrub site were fluxes significantly different overall and through time from the other 5 sites. 
The difference in average $\mathrm{CO}_{2}$ emissions among sites was most pronounced in July when air and soil temperatures were high (Figure 2.3 \& Figure 2.4). A trend toward higher fluxes at the shrub site can be seen in early to mid July (DOY 189-200) (Figure 2.9). Cooling temperatures and rainfall events in August were found to rapidly reduce $\mathrm{CO}_{2}$ efflux. In late August at the wetter sedge and fen sites, average rates of $\mathrm{CO}_{2}$ emissions declined earlier than at the drier heath and shrub sites, seemingly due to large precipitation events which caused substantial water logging and corresponding anaerobic conditions. This trend was also seen at a wet sedge ecosystem in close proximity to the sedge plots of this study in 2004 where ER declined immediately after rainfall events suggesting inhibited $\mathrm{CO}_{2}$ production due to rapid wetting at the surface (Nobrega \& Grogan, 2008).

Methane flux measurements typically indicated a loss of respired carbon from all but the drier heath and shrub ecosystems. However, $\mathrm{CH}_{4}$ uptake due to oxidation of $\mathrm{CH}_{4}$ within the near surface soil layers did occur at the drier sites. Consequently, $\mathrm{CH}_{4}$ flux was significantly different among sites $F_{5,18}=67.05 ; p=<0.0001$ using RM ANOVA and the interaction of vegetation community and time was found to be significant, Wilks $\mathrm{F}_{80,18}=$ $5.10 ; p=0.0001$ indicating that the time variation of $\mathrm{CH}_{4}$ flux is not the same at all sites. This is to be expected as the dry sites are relatively well drained, so large precipitation events would not lead to as large differences in anaerobic conditions, and resulting $\mathrm{CH}_{4}$ flux as the sedge and fen sites. In contrast to $\mathrm{CO}_{2}$ efflux which displayed seasonal variation, $\mathrm{CH}_{4}$ flux displayed little temporal variation at most sites (Figure $2.9 \&$ Figure 2.10). 

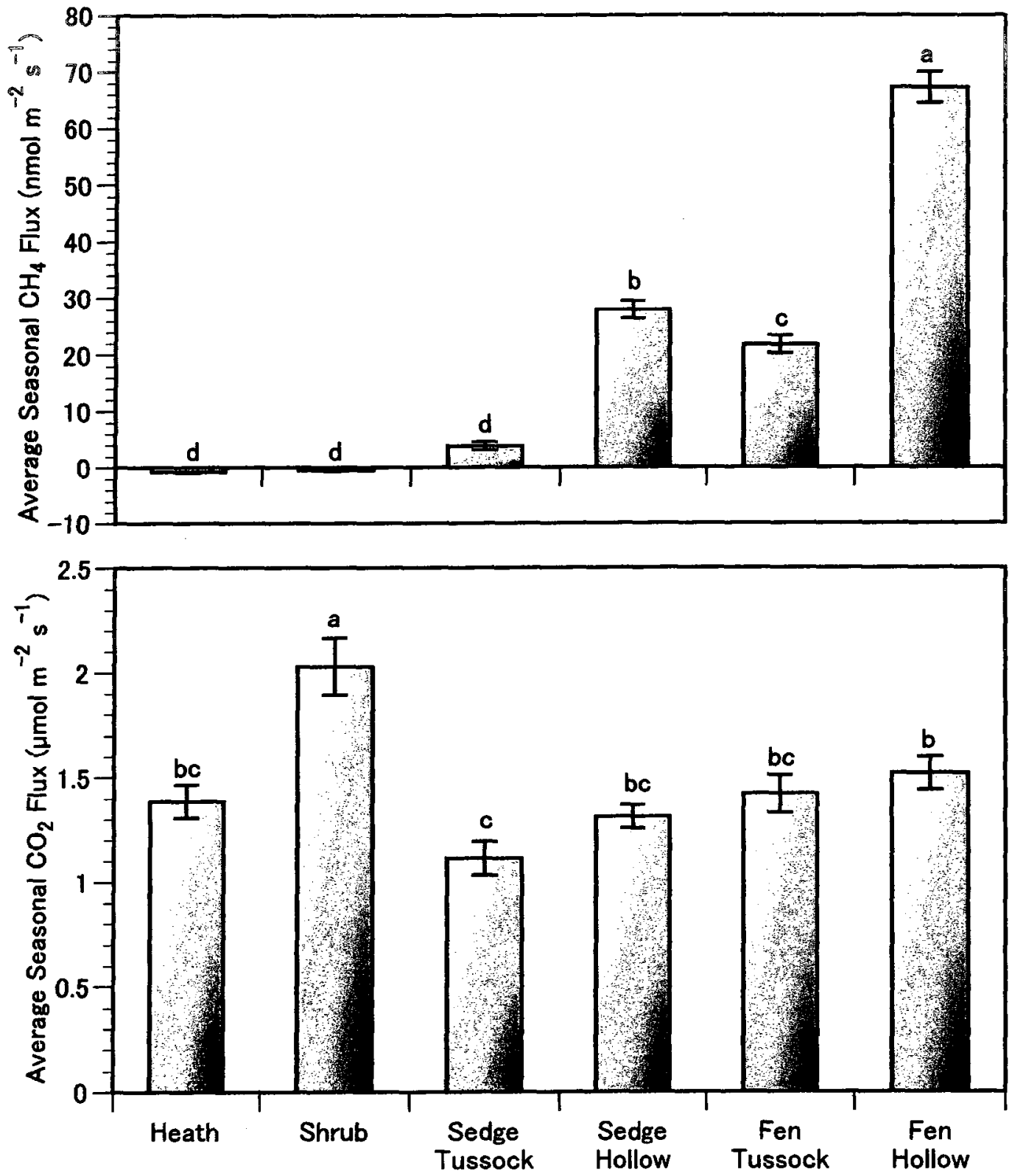

Figure 2.8: Average growing season $\mathrm{CO}_{2}$ and $\mathrm{CH}_{4}$ flux for each vegetation community. Error bars indicate \pm 1 standard error of the mean. Values for each variable that do not share superscript letters in common indicate significant differences between ecosystems (Tukey's HSD, $p<0.05$ ). Negative values indicate ecosystem uptake and positive values indicate loss by the ecosystem. 

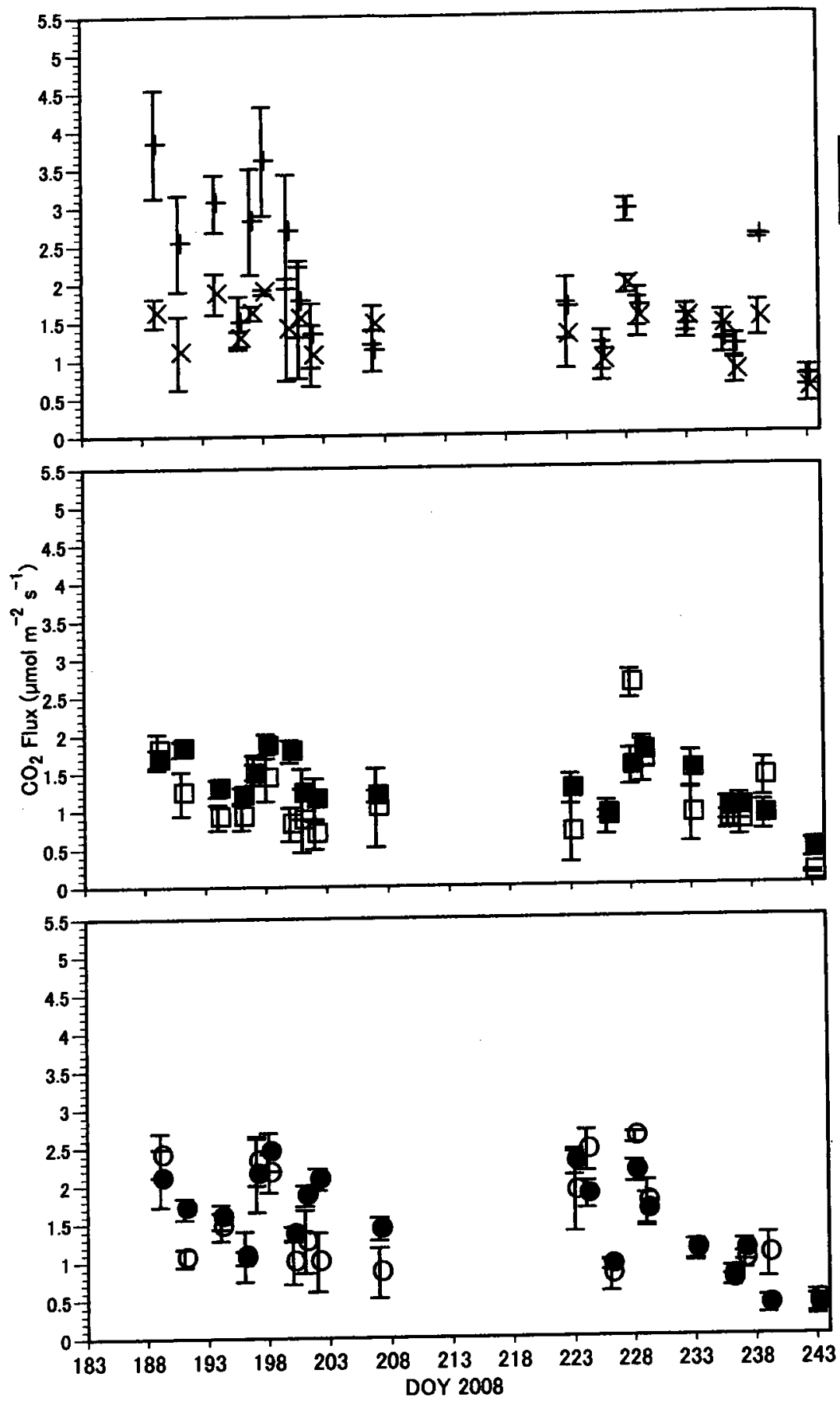

O Fen Tussock

Fen Hollow

Figure 2.9: Average $\mathrm{CO}_{2}$ flux for each vegetation community \pm 1 standard error (SE) measured using the opaque static chamber system. 
Table 2.6: The range and mean (values in brackets indicate \pm 1 standard error of the mean) $\mathrm{CO}_{2}$ flux measured with the opaque static chambers for the six vegetation communities.

\begin{tabular}{llll}
\hline & \multicolumn{3}{c}{$\mathrm{CO}_{2}$ flux $\left(\mu \mathrm{mol} \mathrm{m}^{-2} \mathrm{~s}^{-1}\right)$} \\
& Minimum & Maximum & Mean (SE) \\
\hline Heath & 0.57 & 1.95 & $1.38(0.08)$ \\
Shrub & 0.74 & 3.83 & $2.03(0.20)$ \\
Sedge Tussock & 0.13 & 2.63 & $1.11(0.12)$ \\
Sedge Hollow & 0.45 & 1.85 & $1.31(0.08)$ \\
Fen Tussock & 0.43 & 2.59 & $1.41(0.14)$ \\
Fen Hollow & 0.38 & 2.44 & $1.52(0.13)$ \\
\hline
\end{tabular}


Table 2.7: The range and mean (values in brackets indicate \pm 1 standard error of the mean) $\mathrm{CH}_{4}$ flux measured with the opaque static chambers for the six vegetation communities.

\begin{tabular}{llll}
\hline & \multicolumn{3}{c}{$\mathrm{CH}_{4}$ flux $\left(\mathrm{nmol} \mathrm{m}^{-2} \mathrm{~s}^{-1}\right)$} \\
& Minimum & Maximum & Mean (SE) \\
\hline Heath & -3.1 & -0.1 & $-0.82(0.17)$ \\
Shrub & -2.82 & 0.1 & $-0.50(0.15)$ \\
Sedge Tussock & 0.64 & 11.43 & $3.95(0.75)$ \\
Sedge Hollow & 16.66 & 42.11 & $27.83(1.89)$ \\
Fen Tussock & 12.15 & 39.43 & $21.57(1.53)$ \\
Fen Hollow & 47.89 & 83.58 & $67.26(2.20)$ \\
\hline
\end{tabular}


Average seasonal $\mathrm{CH}_{4}$ efflux was significantly higher at the fen hollow site followed by sedge hollows and then fen tussocks. However, the sedge tussocks were not significantly different than the heath and shrub sites (Figure 2.8a). The maximum, minimum and mean $\mathrm{CH}_{4}$ flux for each vegetation community can be seen in Table 2.7. The drier heath and shrub sites were generally sites of uptake with slightly positive fluxes at times while the moist sedge and wet fen sites were larger sources. At the wetter sites, $\mathrm{CH}_{4}$ emissions were much greater in hollows than the tussocks with greatest emissions at the fen hollows. Hollows were water logged for the whole season while tussocks, particularly at the sedge site were drier with significant zones of aeration.

Increasing rates of $\mathrm{CH}_{4}$ emission coinciding with increasing soil moisture content (after precipitation events) can be most clearly seen at the sedge hollow site (Figure 2.3, Figure $2.4 \&$ Figure 2.10 ). This trend is most noticeable on July $25^{\text {th }}$ (DOY 207) and August $15^{\text {th }}$ (DOY 228) where precipitation events (total precipitation in 5 day period before was 18 and $25 \mathrm{~mm}$ respectively) in the preceding days raised the water table and coincided with increases in average $\mathrm{CH}_{4}$ emission rates. This trend did not occur at the fen hollow site where the water table was $5 \mathrm{~cm}$ or less from the hollow surface such that VWC was high even before the large July and August rainfall events. At these sites, anaerobic conditions were common and resulted in little temporal variation in $\mathrm{CH}_{4}$ production. The tussock sites at the fen and sedge sites also responded only slightly to precipitation events likely due to the rapid drainage of the tussock peat sitting above the water table. 


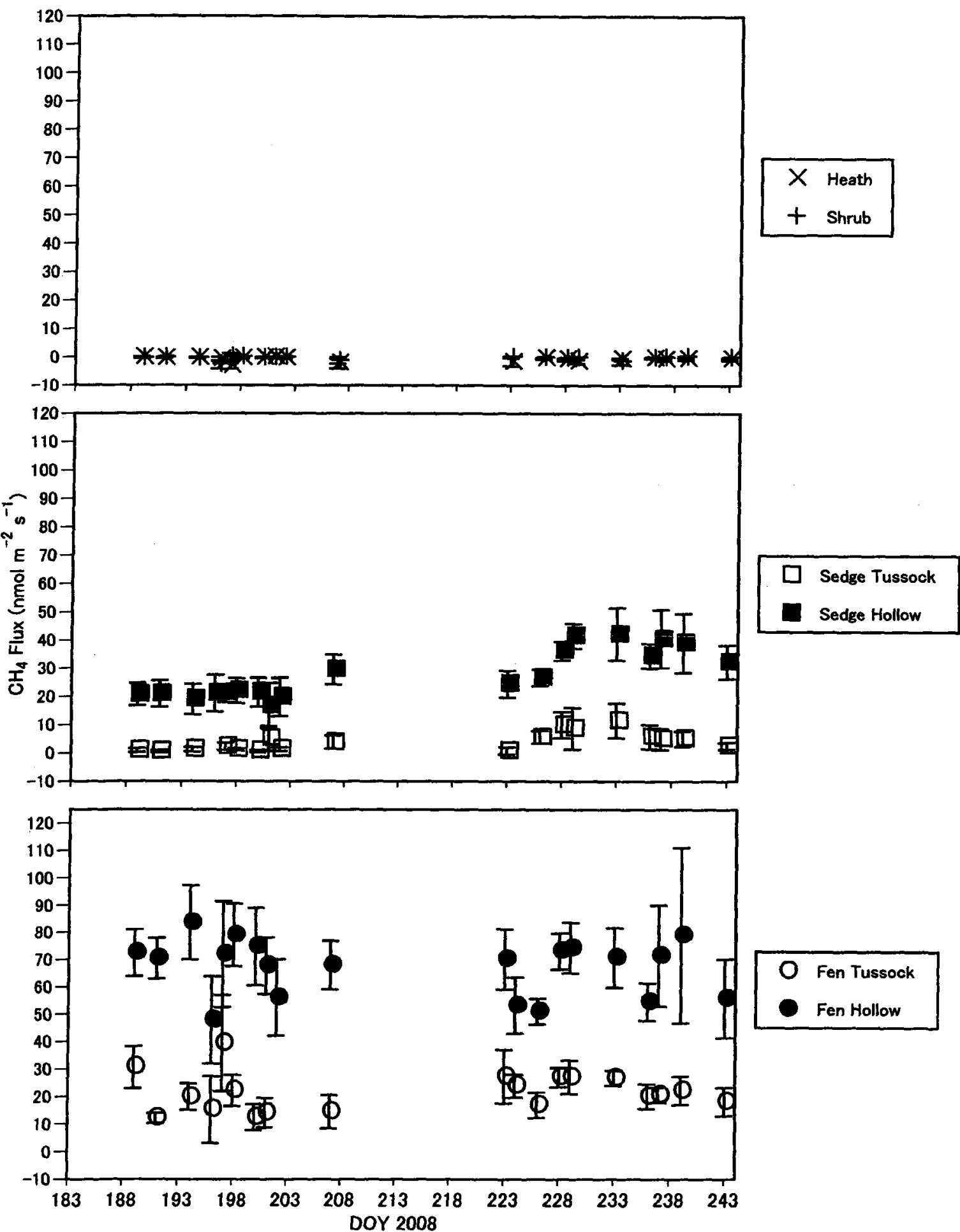

Figure 2.10: Average $\mathrm{CH}_{4}$ efflux for each vegetation community \pm 1 standard error of the mean (SE) where $n=4$ for each vegetation community site. Positive numbers indicate net carbon loss to the atmosphere and negative numbers indicate net ecosystem carbon gain. 


\subsubsection{Examining the Variations in Carbon Fluxes Within Vegetation Communities}

To further examine the factors influencing the temporal variations in carbon fluxes within each vegetation community, correlation analysis was used to determine significant relationships between environmental variables and $\mathrm{CO}_{2}$ and $\mathrm{CH}_{4}$ fluxes (Table $2.8 \&$ Table 2.9). Caution must be taken in interpreting these correlation analysis results as it is difficult to isolate explanatory variables in the field when they often all covary.

Aerobic ecosystem respiration of $\mathrm{CO}_{2}$ is characteristically enhanced with warmer soil temperatures and increasing (but not saturated) soil moisture conditions (Orchard \& Cook, 1983, Davidson et al., 1998; Hamada \& Tanaka, 2001, Risk et al., 2002; Sullivan et al., 2008). Results are largely in agreement with these trends as displayed by the significant positive correlation between $\mathrm{CO}_{2}$ and temperature at the wet sedge hollow, fen tussock and fen hollow sites and VWC at the shrub site (Table 2.8). The negative correlation with VWC at the heath, sedge hollow fen tussock and hollow sites may be due to the increase in anaerobic conditions, which limited ER. At the sedge hollow, fen tussock and fen hollow sites the water table was high and VWC increased greatly with precipitation events. The only positive correlation to VWC was found at the shrub site indicating at this site, which had the lowest average VWC, ER was water limited. Daily precipitation totals were negatively correlated with $\mathrm{CO}_{2}$ fluxes at both the hollow sites, and were positively correlated with daily average atmospheric pressure at both the tussock sites. $\mathrm{CO}_{2}$ efflux was found to be negatively correlated with thaw depth at most sites. However, this trend may have been an artefact as thaw depth was negatively 
correlated with soil temperature at shallow depths as active layer reaches a maximum at the end of the growing season when near surface soil temperatures have already begun to decline (Table 2.8).

Anaerobic respiration of $\mathrm{CH}_{4}$ is generally enhanced with warmer soil temperatures, elevated moisture conditions or position of the water table and presence of vascular vegetation (Funk et al., 1994; Christensen et al., 1998; MacDonald et al., 1998; Friborg et al., 2000; Hargreaves et al., 2001; Kutzbach et al., 2004). Our results also mostly agree with these trends as there was a significant positive correlation with soil temperature at the sedge hollow site and with VWC at the heath, sedge tussock, sedge hollow and fen tussock sites. However, we found a significant negative correlation with temperature for the sedge tussock site. This may be due to soil surface drying and associated higher temperatures. At the dry heath site increasing moisture conditions decreased $\mathrm{CH}_{4}$ uptake rates, possibly due to limits on methane oxidation from increasing anaerobic conditions and/or increasing VWC limiting diffusion into the soil (Crill, 1991).

Additionally, at the sedge and fen sites there was a clear difference between the tussock and hollow sites. The tussocks had aerobic zones where $\mathrm{CH}_{4}$ oxidizes above the water table decreasing $\mathrm{CH}_{4}$ emissions relative to the hummocks, which had little to no aerobic zones throughout the season. Even narrow aerobic zones above the water table have been found to have a high capacity for $\mathrm{CH}_{4}$ oxidation (Whalen et al., 1996). Efflux of $\mathrm{CH}_{4}$ was positively correlated with VWC at the sedge tussock, sedge hollow and fen tussock sites indicating that the fen hollow site already had mostly saturated conditions and precipitation did little to change $\mathrm{CH}_{4}$ emission rates. $\mathrm{CH}_{4}$ emission often only 


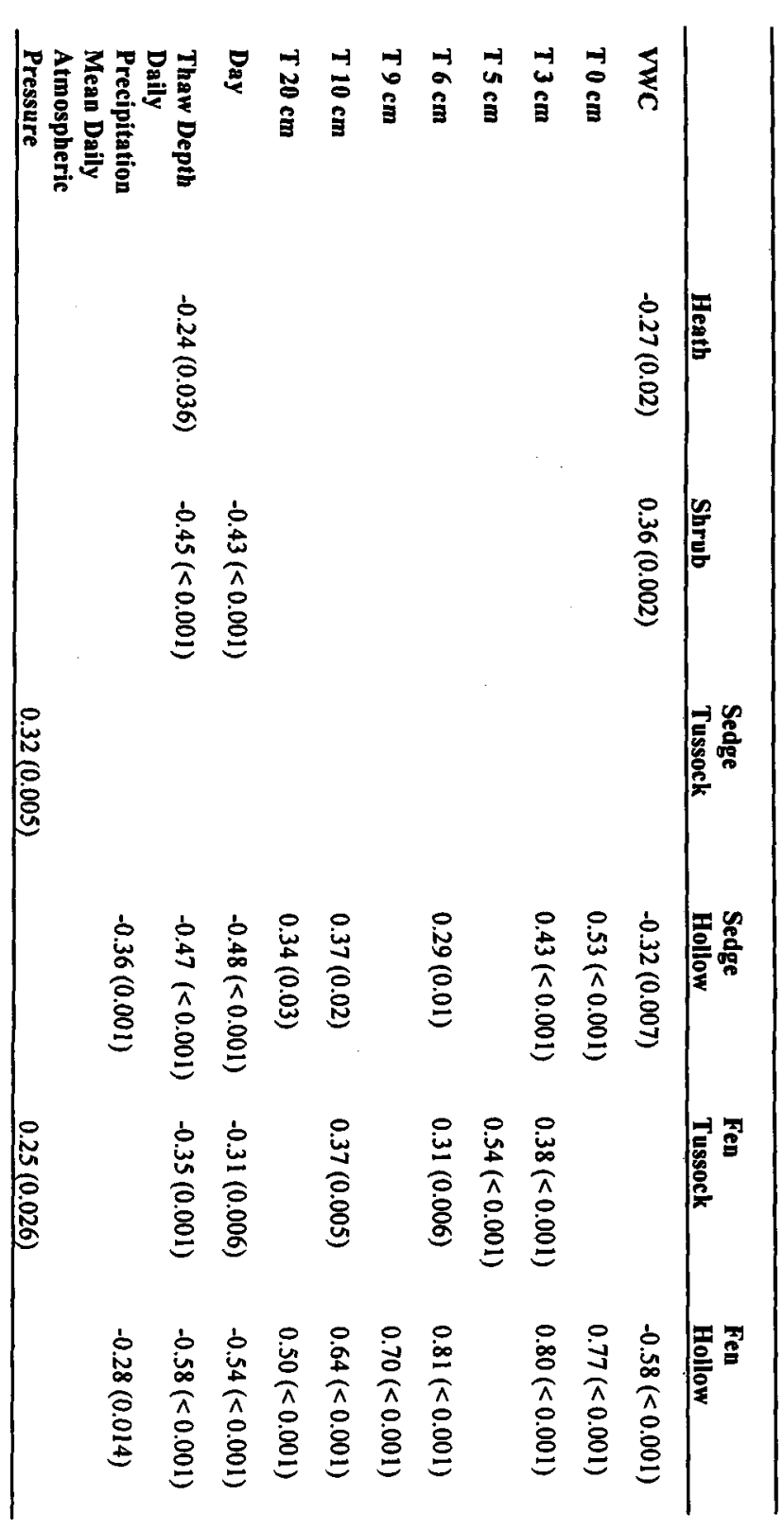

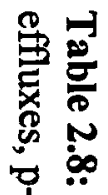

舟

o

릉

og. is

궁

5. 8

용

읏을.

量

8

ह

密

号

క

.

哭

8

.

实



㰻

8 
correlate with soil temperature at sites where the water table is above the soil surface, when it is below aeration gains more importance in controlling $\mathrm{CH}_{4}$ emission (Christensen 1993; Torn \& Chapin, 1993; Nykänen et al., 1998; Sachs et al., 2008). This phenomenon was also observed at the sedge site where only the hollow was positively correlated with temperature but not for the fen hollow as it was only significantly correlated to $\mathrm{CO}_{2}$ in this study (Table 2.9 \& Table 2.11). Yet this could also be an artefact since VWC increased when temperatures were decreasing, which may have decreased aerobic ER, due to an increase in anaerobic environments. Additionally, $\mathrm{CH}_{4}$ was positively correlated with day of year and thaw depth at the sedge tussock and hollow sites however, these again appear to all be correlated with VWC rather than explanatory variables for $\mathrm{CH}_{4}$ flux.

To examine the short-term temporal variation in $\mathrm{CO}_{2}$ and $\mathrm{CH}_{4}$ at a saturated site, chamber measurements were taken at all plots from 8 am to $4 \mathrm{pm}$ over three days during the growing season (Figure 2.11). The efflux of $\mathrm{CO}_{2}$ shows clear temporal variation on two of the three sampling days with increasing efflux at both the tussocks and hollows. In addition, $\mathrm{CO}_{2}$ efflux decreases with day of year when by August $28^{\text {th }}$ (DOY 241), temporal variations in $\mathrm{CO}_{2}$ efflux are negligible. The efflux of $\mathrm{CH}_{4}$ shows only a small amount of diurnal variation and little seasonal variation (Figure 2.11). Instead topography greatly affects $\mathrm{CH}_{4}$ efflux as efflux from the hollows was greater than tussocks for all three days due to saturated conditions at the hollows while the tussocks remained above the water table and maintained zones of aeration. 
Table 2.9: Spearman's correlation coefficients showing significant relationships between environmental variables and $\mathrm{CH}_{4}$ fluxes, $\mathrm{p}$-values are given in brackets.

\begin{tabular}{|c|c|c|c|c|c|c|}
\hline & Heath & Shrub & $\begin{array}{l}\begin{array}{l}\text { Sedge } \\
\text { Tussock }\end{array} \\
\end{array}$ & $\begin{array}{l}\text { Sedge } \\
\text { Hollow }\end{array}$ & $\begin{array}{l}\text { Fen } \\
\text { Tussock }\end{array}$ & $\begin{array}{l}\text { Fen } \\
\text { Hollow } \\
\end{array}$ \\
\hline vwc & $0.48(<0.001)$ & & $0.43(<0.001)$ & $0.44(<0.001)$ & $0.42(<0.001)$ & \\
\hline $\mathbf{T} \mathbf{3 c m}$ & & & $-0.31(0.01)$ & & & \\
\hline T $6 \mathrm{~cm}$ & & & $-0.27(0.03)$ & & & \\
\hline T $20 \mathrm{~cm}$ & & & & $0.33(0.03)$ & & \\
\hline T $30 \mathrm{~cm}$ & & & & $0.35(0.03)$ & & \\
\hline Day & & & $0.39(<0.001)$ & $0.53(<0.001)$ & & \\
\hline Thaw Depth & & & $0.34(0.005)$ & $0.52(<0.001)$ & & \\
\hline
\end{tabular}



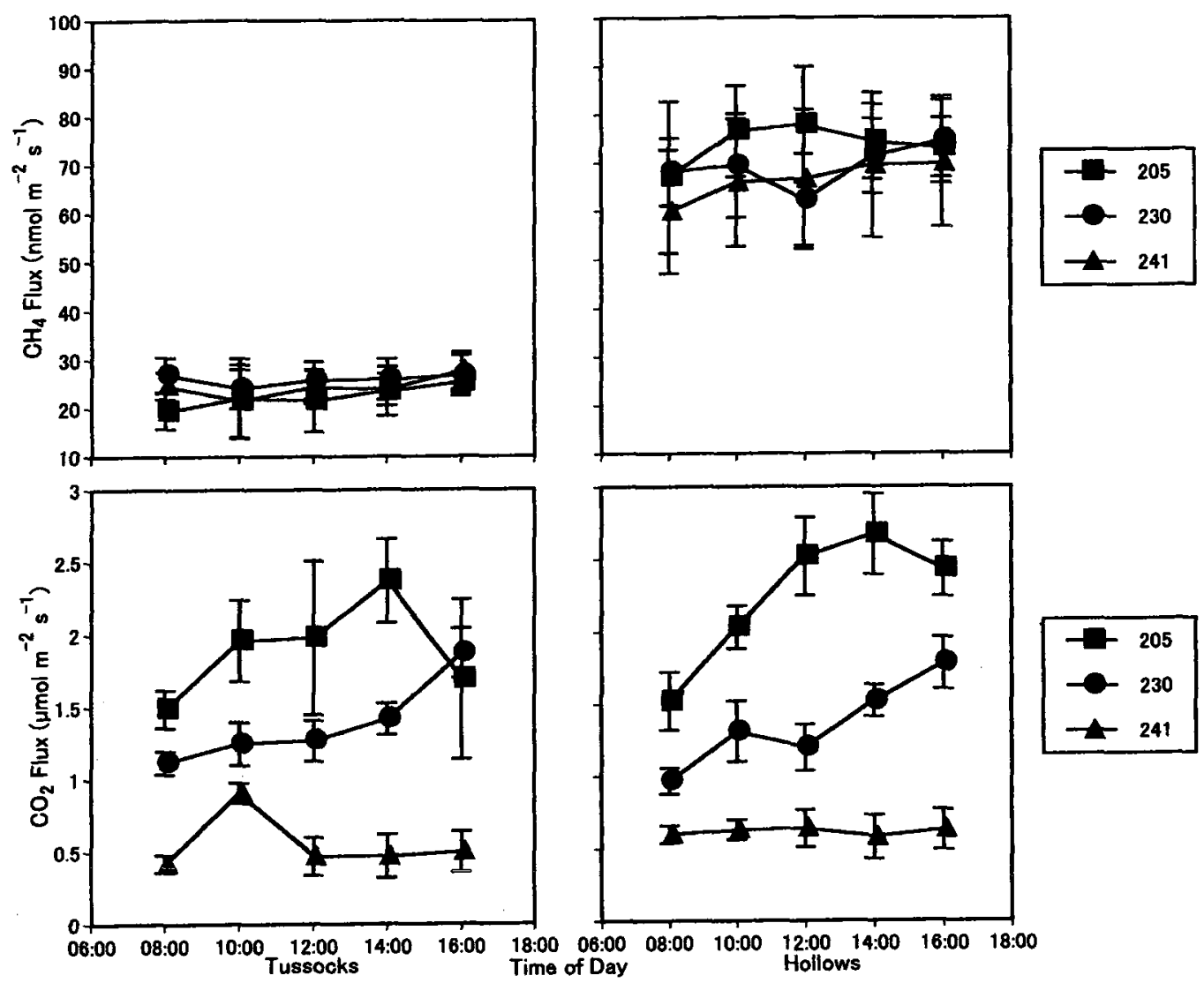

Figure 2.11: $\mathrm{CO}_{2}$ and $\mathrm{CH}_{4}$ efflux from 8 am to 4 pm over three days (squares, July $23^{\text {rd }}$, circles, August $17^{\text {th }}$ and triangles, August $28^{\text {th }}$ ) during the 2008 growing season \pm 1 standard error of the mean. 
Correlation analysis was used to examine the correlation between NEE and its component fluxes GEP and ER, and $\mathrm{CO}_{2}$ efflux and $\mathrm{CH}_{4}$ flux (Table 2.10 \& Table 2.11). NEE is correlated to GEP at all sites while NEE is only correlated to ER at the heath and fen hollow sites (Table 2.10). At the sedge tussock both $\mathrm{CO}_{2}$ efflux and $\mathrm{CH}_{4}$ flux have a negative correlation to NEE (with less net carbon uptake, $\mathrm{CO}_{2}$ and $\mathrm{CH}_{4}$ efflux also decrease), while at the fen hollow $\mathrm{CO}_{2}$ efflux has a positive correlation to NEE (with less net carbon uptake $\mathrm{CO}_{2}$ efflux increase) (Table 2.11). At the fen tussock, $\mathrm{CH}_{4}$ flux has a negative correlation to GEP and a positive correlation to ER suggesting that controls on carbon assimilation were not the same as controls on $\mathrm{CH}_{4}$ production in these environments. ER (measured with the NEE chamber system) was positively correlated with $\mathrm{CO}_{2}$ efflux (measured using the opaque static chambers) suggesting good agreement between the two measurement techniques. Efflux of $\mathrm{CO}_{2}$ was negatively correlated with $\mathrm{CH}_{4}$ flux at the heath site and positively correlated at both fen sites, indicating that at the heath site increasing anaerobic conditions had opposite effects on $\mathrm{CO}_{2}$ and $\mathrm{CH}_{4}$ flux, while at the fen both $\mathrm{CO}_{2}$ and $\mathrm{CH}_{4}$ flux may have had similar controls. 
Table 2.10: Spearman's correlation coefficients showing significant relationships between NEE and its component fluxes GEP and ER, p-values are given in brackets.

\begin{tabular}{lcc}
\hline & GEP & ER \\
\hline Heath & $0.68(<0.001)$ & $0.55(0.007)$ \\
Shrub & $0.82(<0.001)$ & \\
Sedge Tussock & $0.85(<0.001)$ & \\
Sedge Hollow & $0.82(<0.001)$ & \\
Fen Tussock & $0.86(<0.001)$ & \\
Fen Hollow & $0.84(<0.001)$ & $0.47(0.02)$ \\
\hline
\end{tabular}




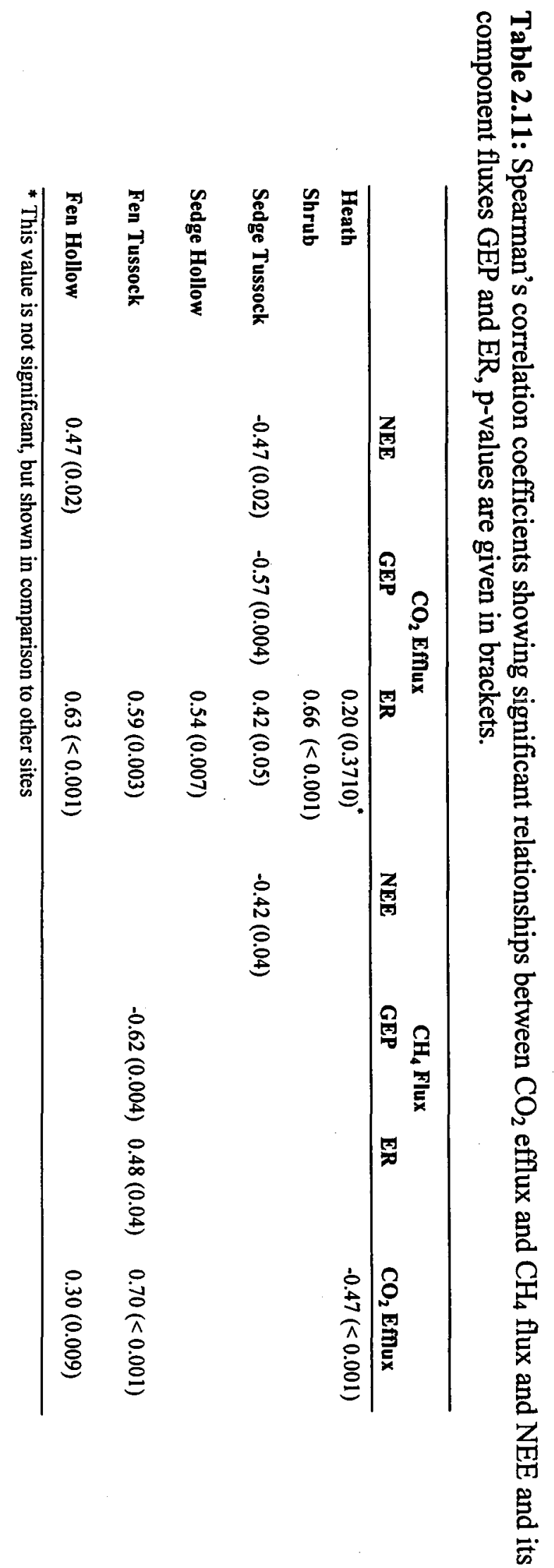




\subsubsection{Examining the Variations in Carbon Fluxes Among Vegetation Communities}

Variation in NEE among sites was largely attributed to soil moisture status (Figure 2.12). The three drier sites, heath, shrub and sedge tussock had lower average net uptake than the three wetter sites, sedge hollow, fen tussock and fen hollow (Figure 2.12a). There is not as clear a relationship between $\mathrm{CO}_{2}$ efflux and VWC. The shrub site, which was the driest site, had the highest emission rates in comparison to the other sites (Figure 2.12b). As expected, sites with higher VWC had larger fluxes of $\mathrm{CH}_{4}$ as seen by the exponentially increasing relationship (Figure 2.12c) as anaerobic conditions increase with increasing water content.

Several studies have found correlations with $\mathrm{CH}_{4}$ flux and atmospheric pressure at peatland sites (Kellner et al., 2006; Tokida et al., 2007), however we did not find any clear trends upon visual examination of our results (Figure $2.3 \&$ Figure 2.10 ) or significant correlation in our statistical analysis (Table 2.9). Our chamber flux measurements may not have been able to capture the effects of changes in pressure due to both the non-continuous nature of chamber sampling and the alteration of the pressure gradients due to the use of closed chambers. 

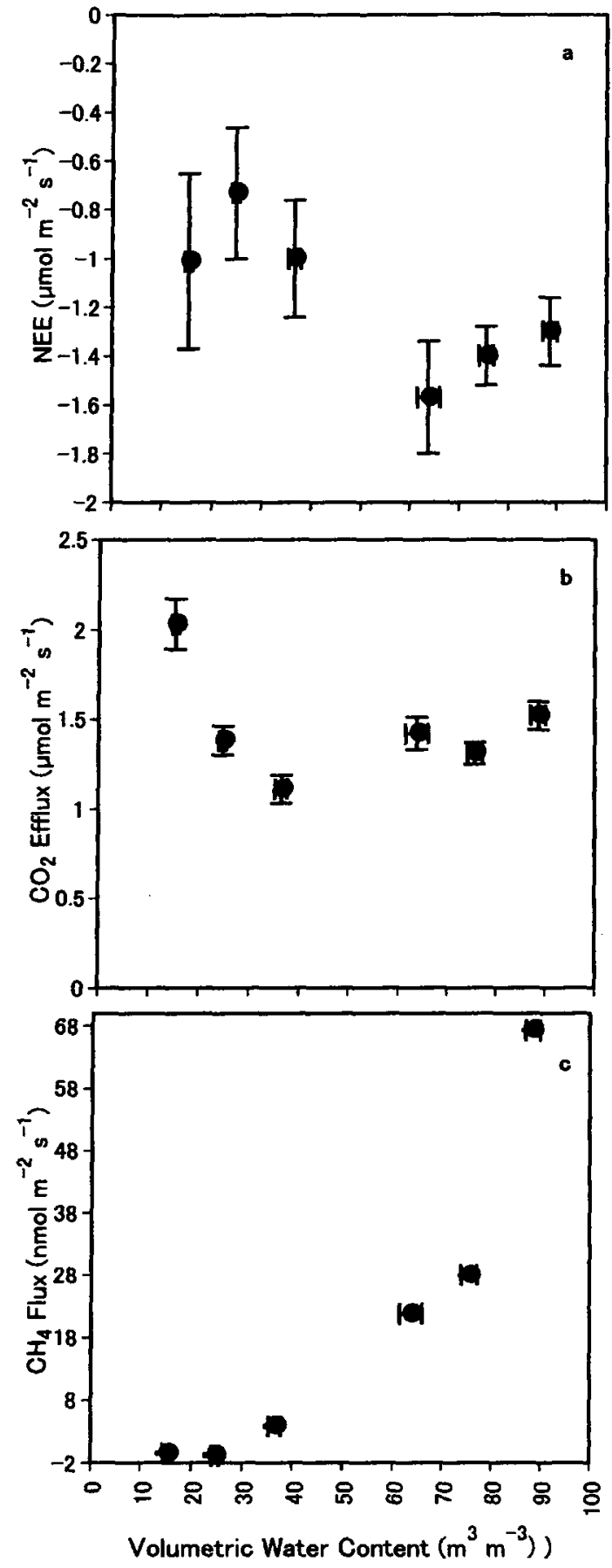

Figure 2.12: Average seasonal $\mathrm{NEE}, \mathrm{CO}_{2}$ efflux and $\mathrm{CH}_{4}$ flux versus volumetric water content $(\mathrm{VWC})\left(\mathrm{m}^{3} \mathrm{~m}^{-3}\right) \pm 1$ standard error (SE) for each of the six vegetation communities. Negative values indicate ecosystem uptake and positive values indicate loss of carbon by the ecosystem. 


\subsubsection{Modeled Carbon Balance and Global Warming Potential}

Parameters obtained from Equation 2.2 (Table 2.4) were used to model July and August NEE in combination with PAR and T. NEE estimates in combination with average $\mathrm{CH}_{4}$ efflux values were used to model the carbon balance and global warming potential of the six vegetation communities studied (Table 2.12). Average values of $\mathrm{CH}_{4}$ were assumed to be acceptable approximation of the total $\mathrm{CH}_{4}$ emissions since in most cases, little temporal variation was found in $\mathrm{CH}_{4}$ effluxes on either short or long-term periods (Figure 2.10 \& Figure 2.11).

All sites, except the heath were net carbon sinks over the two month period with the largest sinks at the sedge hollow and fen tussock sites. For the 20 -year horizon only the shrub and sedge tussock sites had net negative forcing potentials. The sedge hollow, fen tussock and fen hollow had net positive forcing potentials due to large $\mathrm{CH}_{4}$ emissions. On a 100-year timescale the shrub, sedge tussock and fen tussock sites had net negative forcing potentials and the others have net positive forcing potentials (Table 2.12). 
Table 2.12: Modeled carbon balance and global warming potential (GWP) for each site for July and August 2008. Positive numbers indicate carbon loss to the atmosphere and negative numbers indicate carbon gain.

\begin{tabular}{|c|c|c|c|c|c|c|}
\hline & Heath & Shrub & $\begin{array}{c}\text { Sedge } \\
\text { Tussock }\end{array}$ & $\begin{array}{c}\text { Sedge } \\
\text { Hollow }\end{array}$ & $\begin{array}{c}\text { Fen } \\
\text { Tussock }\end{array}$ & $\begin{array}{c}\text { Fen } \\
\text { Hollow }\end{array}$ \\
\hline $\begin{array}{l}\text { Carbon Balance } \\
\left(\mathrm{g} \mathrm{C} \mathrm{m}^{-2}\right)\end{array}$ & 6.44 & -12.45 & -9.56 & -14.28 & -24.44 & -5.31 \\
\hline $\begin{array}{l}\text { GWP ( } 20 \text { yr horizon) } \\
\left(\mathrm{g} \mathrm{CO}_{2} \mathrm{~m}^{-2}\right)\end{array}$ & 18.77 & -48.77 & -12.218 & 113.35 & 39.4 & 379.75 \\
\hline $\begin{array}{l}\text { GWP }(100 \mathrm{yr} \\
\text { horizon) }\left(\mathrm{g} \mathrm{CO}_{2} \mathrm{~m}^{-2}\right)\end{array}$ & 22 & -46.66 & -27.71 & 0.87 & -48.17 & 108.78 \\
\hline
\end{tabular}




\subsection{Discussion}

Within tundra landscapes there is considerable heterogeneity due to topographic variation. This heterogeneity creates spatial variation in environmental variables such as temperature, hydrology, vegetation cover and active layer depth throughout the growing season. As a result, controls on ecosystem carbon exchange are complex and site specific (Oberbauer et al., 1991; Christensen et al., 2000). This study of $\mathrm{CO}_{2}$ and $\mathrm{CH}_{4}$ tundraatmosphere exchange for six vegetation community plots; heath, shrub, sedge tussock, sedge hollow, fen tussock and fen hollow revealed considerable spatial variability in $\mathrm{CO}_{2}$ and $\mathrm{CH}_{4}$ flux due to intrinsic site factors with a particular emphasis on the influence of soil moisture conditions.

This research builds upon an earlier study by Nobrega and Grogan (2008) who measured NEE and each of its component fluxes at heath, shrub and sedge tussock sites at Daring Lake, N.W.T during the 2004 growing season. Our research further examines spatial variation in moist and wet areas in the landscape by measuring both tussocks and hollows in these areas and includes measurements of $\mathrm{CH}_{4}$ efflux at all sites to provide a more complete picture of the total carbon budget and the radiative forcing potential across the landscape.

Results in 2008 are largely similar to results to those obtained in 2004 . Hydrology was an important driver of $\mathrm{CO}_{2}$ exchange among vegetation communities in both years. Additionally, we found hydrology was key in explaining the high spatial variability of $\mathrm{CH}_{4}$ flux among vegetation communities. The large control of hydrology on spatial 
variability of carbon fluxes is consistent with other arctic studies (Sjögersten et al., 2006; van der Molen et al., 2007; Sommerkorn, 2008).

\subsection{1. $\mathrm{CO}_{2}$ Exchange}

In order to gain a mechanistic understanding of the controls on NEE fluxes among vegetation communities, each of the component fluxes of NEE, GEP and ER must be investigated. Small relative changes in GEP or ER can cause large relative changes of NEE and both components are dependent on many similar environmental variables, making it difficult to establish the driving controls on NEE. Attempting to determine if it is GEP or ER that leads to the variability in NEE among sites is challenging. Field measurements, which are a function of temperature conditions among sites, suggest ER is just as variable as GEP (GEP range, $0.98 \mu \mathrm{mol} \mathrm{m}^{-2} \mathrm{~s}^{-1}$ versus ER range of $0.97 \mu \mathrm{mol} \mathrm{m}{ }^{-2}$ $\left.\mathrm{s}^{-1}\right)$. When we applied a model, normalizing temperature conditions among sites, GPmax was more variable than $R_{10}$ as displayed by the larger range of values $\left(3.45 \mu \mathrm{mol} \mathrm{m} \mathrm{m}^{-2}\right.$ for GPmax versus $0.4 \mu \mathrm{mol} \mathrm{m} \mathrm{m}^{-2} \mathrm{~s}^{-1}$ for $\mathrm{R}_{10}$ ). The comparison of these two methods allows for an examination of carbon exchange among sites in situ and inherent differences due to plant species and microbial processes.

Examining NEE variability among vegetation communities with the model we found NEEmax to be greater in magnitude (more uptake) at the wetter versus the drier sites. These higher rates of net uptake at the wet sites were generally due to high rates of GEP and lower ER. Large rates of $\mathrm{CO}_{2}$ uptake have been documented at many fen sites across the arctic while low rates of uptake at upland heath sites, such as the one in this 
study are common (Grøndahl et al., 2008; Arndal et al., 2009). Observations of greater $\mathrm{CO}_{2}$ uptake rates when compared with other dry tundra surfaces mean that shrub sites are often carbon sinks while other dry sites are sources of carbon (Nykänen et al., 2003). In our study, shrub sites were typically associated with greater $\mathrm{CO}_{2}$ uptake than heath sites under full-light conditions.

Differences in vascular photosynthetic capacity between functional types may aid in explaining differences in GEP. A study by Limbach et al. (1982) examined photosynthetic capacity and root respiration among plant species from arctic tundra. Photosynthetic capacity was highest for a graminoid species followed by a deciduous shrub and lowest for the evergreen shrub. Assimilation rates were high for the graminoid and shrub species due to their deciduous growth form. The evergreen shrub however had a longer duration of photosynthesis over the growing season and lower optimum temperatures. This relative order of photosynthetic capacity is also confirmed by a later study on 19 arctic vascular plant species which found that maximum assimilation rates were higher for graminoids, then deciduous shrubs and lastly evergreen shrubs (Oberbauer \& Oechel, 1989).

Differences in nitrogen content of photosynthesizing vegetation tissue have also been suggested to control differences in GEP among vegetation types (Williams \& Rastetter, 1999). The low rates of GEP in evergreen shrubs has been linked to low nitrogen content and the increased leaf longevity in plants in comparison to faster growing species with higher nitrogen content and GEP in fen ecosystems (Arndal et al., 
2009). Shrub vegetation has high nutrient requirements to support new growth resulting in high rates of GEP and high element content in leaves (Shaver et al., 1996).

Both the differences in photosynthetic capacity and nitrogen content between functional types can aid in interpreting the differences in GEP among the six vegetation community plots. In our study the highest rates of uptake (GPmax) occurred at the fen site where sedge species flourish, followed by the shrub site where deciduous shrubs are plentiful. Lower GPmax values were found at the heath site, which is dominated by evergreen shrubs. Higher nitrogen content has been found in both fen vascular and moss tissue, and deciduous shrub species (Shaver et al., 1996; Arndal et al., 2009).

Mosses are an important part of tundra plant communities and have been shown to contribute to carbon exchange in arctic ecosystems. The contribution of mosses to GEP can be substantial, particularly in plots with continuous moss cover beneath the canopy (Sommerkorn et al., 1999; Douma et al., 2007; Arndal et al., 2009; Campioli et al., 2009). In our study, the site with the highest moss cover had the highest rates of net uptake, however the direct connection between NEE and moss cover cannot be made as carbon exchange was not separated into vascular and non-vascular contributions.

At the moist and wet sites ER was not significantly different from the dry heath site (according to both field chamber measurements) despite marked differences in vegetation cover, soil carbon stocks, soil texture, moisture and thaw regimes. ER measurements made with the NEE chamber system, as well as $R_{10}$ values from the model show no significant difference among the heath and shrub site, yet static opaque chamber measurements, which were used 3 times as often and for the whole field season indicate 
the shrub site had significantly higher $\mathrm{CO}_{2}$ effluxes than all other sites, including the heath. Although the heath and shrub sites have similar soil textures and thaw regimes, the differences in vegetation and associated litter and soil temperatures lead to great differences in ER rates. Results from an Alaskan arctic transect study also found that in low arctic ecosystems growing season rates of ER tend to be similar among sites even with contrasting hydrology (McFadden et al., 2003). Additionally, Williams et al. (2006) found that there was low variability in ER among vegetation types within a low arctic catchment.

Ecosystems dominated by different functional types are suggested to differ in their rates and patterns of soil element cycling largely due to the litter quality (Shaver et al., 1996). By examining the soil respiration component of ER, Nobrega and Grogan (2008) found substantial ecosystem differences in carbon turnover rates within bulk and plant associated pools. Since more than two thirds of ER was from soil respiration at the shrub site, while the heath and sedge sites had ratios under half, it was suggested that there was a higher turnover rate of soil carbon in the shrub ecosystem. It was suggested that rapidly decomposable litter associated with deciduous shrubs results in high element turnover required for the high maintenance of new growth and associated high uptake rates (Shaver et al., 1996). Root respiration of deciduous shrubs have been found to be lower than graminoid species and evergreen shrubs (Limbach et al., 1982) supporting the hypothesis that at our shrub site the majority of ER would have been due to heterotrophic respiration. The higher temperatures at the shrub site in combination with large soil $\mathrm{C}$ pools led to significantly higher ER. 
Interestingly, although both the sedge tussock and hollow sites were located within a small water logged area, rates of GEP and ER were quite different due to microtopography. The tussocks were zones of low density peat situated above the water table for most of the season, allowing for significantly warmer and drier microenvironments where GEP was lower and ER was higher. The sedge tussock site was more similar to our dry heath and shrub sites than the other wet sedge and fen sites until large precipitation events in August increased VWC substantially.

For many arctic tundra landscape studies LAI is derived from normalizeddifference vegetation index (NDVI) and used to describe spatial variation in $\mathrm{CO}_{2}$ flux. Shaver et al. (2007) suggest a high level of convergence in canopy structure allows for good estimates of NEE from LAI. An LAI- foliar nitrogen content relationship has also been suggested to be the major control on ecosystem photosynthetic capacity, independent of species composition (van Wijk et al., 2005). In contrast to other findings examining arctic $\mathrm{CO}_{2}$ exchange at various ecosystem types at the landscape or regional scale (Oechel et al., 2000; Mcfadden et al., 2003; Williams et al., 2006; Street et al., 2007) LAI did not explain differences in GEP or NEE among vegetation communities at the plot scale. This suggests that due to the small scale variability in arctic vegetation communities and associated variations in photosynthetic capacity, soil types and environmental conditions $\mathrm{LAI}$ alone cannot predict $\mathrm{CO}_{2}$ exchange dynamics. This research suggests $\mathrm{CO}_{2}$ exchange is highly dependent on both vegetation community type and associated photosynthetic capacity and biomass and hydrology. 
The range of field measurements of NEE, GEP and ER is similar to those found in 2004 by Nobrega and Grogan (2008). Values of ER at the heath site are similar to upland heath tundra in Alaska and the high arctic (Oberbauer et al., 1996; Illeris et al., 1999) and $\mathrm{CO}_{2}$ exchange rates of dry and wet surfaces are similar to those at a subarctic site (Nykänen et al., 2003). NEE values in heath, sedge and fen were comparable to those in the high arctic (Grøndahl et al., 2008). Heath NEE was within the range found in low arctic Alaska sites but shrub values were lower and wet sites higher in our study (McFadden et al., 2003). Rates of ER at our wet sedge and fen sites were tending toward the lower end of results of tussock tundra, wet sedge tundra, and low-centre polygonal tundra in central Siberia (Sommerkorn, 2008). This is in contrast to recent eddy covariance based estimates of tundra NEE that suggest increasing net $\mathrm{CO}_{2}$ uptake in tundra located at more southerly latitudes during peak biomass period of the growing season (E. Humphreys, personal communication). Consequently, spatial and temporal scaling issues might confound identifying clear regionally based differences in carbon exchange rates for arctic ecosystems when using chamber-based ecosystems.

\subsection{2. $\mathrm{CH}_{4}$ Exchange}

In contrast to $\mathrm{CO}_{2}$ exchange, there was considerable variability in $\mathrm{CH}_{4}$ exchange among vegetation communities largely due to the differences in VWC. Wet sedge and fen sites were sources of $\mathrm{CH}_{4}$ while the dry heath and shrub sites were sinks to slight sources. The trend of greater $\mathrm{CH}_{4}$ emissions occurring at sites with greater VWC is commonly found within the Arctic (Christensen et al., 1995). High spatial variability was also seen within wet systems as hollows had much higher rates of emission than tussocks and both 
the sedge and fen sites. The large differences in emissions between the tussock and hollow sites are due to the position of the water relative to microtopography. The water table was close to or above the moss surface at the hollows for the majority of the season while the tussocks had zones of aeration above the water table. The water table control on $\mathrm{CH}_{4}$ emission has been seen in many other arctic $\mathrm{CH}_{4}$ flux investigations (Morrissey \& Livingston, 1992; Christensen et al., 2000; van der Molen et al., 2007; Grøndahl et al., 2008). In these cases controls on $\mathrm{CH}_{4}$ transport and oxidation become as important as production in determining rates of emission. Oxidation of $\mathrm{CH}_{4}$ in the aerobic zone decreases $\mathrm{CH}_{4}$ emission while the presence of vascular vegetation such as sedges provide a conduit through the oxidation zone, increasing emission (Whalen \& Reeburgh, 1990; Torn \& Chapin, 1993; Schimel, 1995; King et al., 1998).

Within vegetation communities, temporal controls on $\mathrm{CH}_{4}$ emission were also largely attributed to VWC. The control of temperature on $\mathrm{CH}_{4}$ emission was not clearly apparent at all the sites in this study despite $\mathrm{CH}_{4}$ emission often being correlated with soil temperature at waterlogged sites in other studies (Christensen, 1993; Torn \& Chapin, 1993; Nykänen et al., 1998; Sachs et al., 2008). There was a positive correlation between temperature and emission at the sedge hollow but not for the fen hollow. As we did not find a significant relationship to environmental drivers at the fen hollow we speculate that $\mathrm{CH}_{4}$ exchange may be regulated by productivity at this site. In waterlogged zones ecosystem productivity rates are often found to be a main driver in $\mathrm{CH}_{4}$ exchange as sedge root exudation and decomposition provide substrate for methanogenesis (Bellisario 
et al., 1999; Christensen et al., 2000; Nykänen et al., 2003; Ström et al., 2003; van der Molen et al., 2007).

Variability in $\mathrm{CH}_{4}$ emissions across the arctic is large however the rates observed in this study are within the range observed by other researchers (Christensen et al., 1995; Grøndahl et al., 2008). The range of uptake rates at the dry heath and shrub sites are similar to those found in Yukon tundra (Barlett et al., 1992). Our measurements of $\mathrm{CH}_{4}$ efflux within the wet sites were similar to some other arctic sites (Kutzbach et al., 2004; Rinne et al., 2007) but lower than other sites (Bartlett et al., 1992; Nakano et al., 2000; Corradi et al., 2005) which may be because of site/microsite differences.

\subsubsection{Temporal Variations in Carbon Exchange}

Our July and August field season allowed for investigation of carbon exchange throughout the summer and early fall periods of this low arctic growing season. Rates of $\mathrm{CO}_{2}$ uptake and emission showed a seasonal trend with higher rates associated with high PAR and air temperatures, which also controlled conditions for plant growth. By the fall (August $15^{\text {th }}$-September) PAR and air and soil temperatures show a decreasing trend and vegetation was senescing. This results in substantial decreases in both GEP and ER.

In most years there is a gradual drying across the landscape throughout the summer season. However, due to substantial precipitation events in August 2008 and corresponding increase in VWC and water table level at all sites there was an increase in $\mathrm{CH}_{4}$ flux during this period, particularly at both the sedge tussock and hollow sites. This led to increased temporal variability in $\mathrm{CH}_{4}$ emissions at the sedge site in particular in this fall season. It is estimated that in drier years as temperatures decrease in the fall $\mathrm{CH}_{4}$ 
emission would decrease as well. But perhaps in 2008 the increasing anaerobic conditions were the strongest control of $\mathrm{CH}_{4}$ emissions.

Results from intensive sampling over three days at the fen indicate that $\mathrm{CO}_{2}$ had both large diurnal and seasonal variation while the diurnal and seasonal variation of $\mathrm{CH}_{4}$ was minimal. This shows that both light and temperature seem to have little control over temporal changes in $\mathrm{CH}_{4}$ fluxes suggesting that even if productivity is important in stimulating anaerobic decomposition with the delivery of easily decomposable substrates such as root exudates, it does not appear to have a strong short-term influence on observed $\mathrm{CH}_{4}$ fluxes. An absence of a diurnal pattern in $\mathrm{CH}_{4}$ flux has been found in other studies examining different subarctic tundra environments (Heyer et al., 2002) and a boreal fen (Rinne et al., 2007). These researchers suggested that peat temperature in the deeper layers below the water table was the major environmental parameter controlling $\mathrm{CH}_{4}$ emission and therefore a lack of a diurnal $\mathrm{CH}_{4}$ cycle was due to a lack or diurnal temperature change in the deep peat profile.

\subsubsection{Growing Season Carbon Balance \& Global Warming Potential}

Modeled growing season flux estimates suggest that for the July and August 2008 period the heath was a net source of carbon and the other 5 sites were all net sinks. In 2008 the fen tussock had the largest carbon uptake of all sites and the hollow had the lowest. Measured soil organic matter content also supports estimates that the heath site is a net carbon source, due to its low soil organic matter content and that the wet sites are net carbon sinks, as demonstrated by the substantial peat accumulation. 
By including measurements of $\mathrm{CH}_{4}$ in our research we attempt to give more representative estimates of the growing season carbon budget and associated radiative forcing potential in the six vegetation community plots. All sites except the heath were net carbon sinks, though by including $\mathrm{CH}_{4}$ measurements most of the wet sites produced positive radiative forcing on a 20 year timescale with both the sedge and fen hollows remaining a positive radiation forcing on a 100 year timescale. Caution must be taken in the interpretation of these statements, as the GWP methodology (IPCC, 2007) is highly dependent on the choice of time horizon. Moreover, emission results from carbon cycling studies are treated as isolated pulse emissions rather than as complete assessments of the long-term impact of an ecosystem on radiative forcing and the climate system (Frolking et al., 2006). Since the radiative effect of sustained carbon uptake and $\mathrm{CH}_{4}$ emissions cannot be analyzed using GWP methodology, atmospheric budget models and time series estimates of net $\mathrm{CO}_{2}$ and $\mathrm{CH}_{4}$ fluxes have been used (Frolking et al., 2006; Frolking \& Roulet, 2007). The results suggest that peatland development initially results in net positive forcing (warming) for the first few decades, but the radiative effects of sustained carbon uptake slowly become dominant on longer timescales resulting in a net atmospheric cooling on the climate system (Frolking et al., 2006; van der Molen et al., 2007).

Our study only includes flux measurements over the growing season. However, wintertime fluxes may constitute a considerable part of the annual balances (Chapin et al., 2000; Soegaard et al., 2000; Heikinnen et al., 2002). Incorporating non-growing season fluxes into the carbon balance may cause many of these sites to be carbon sources. 
Therefore, making measurements during the fall, spring and winter seasons is critical in making more accurate estimations of the current carbon balance of arctic ecosystems. This information will assist modeling efforts to more accurately understand and quantify climate feedbacks in these northern environments.

\subsubsection{Potential Effects of Climate Change}

The effects of climate change on carbon cycling may differ substantially among arctic ecosystems (Elberling et al., 2008). Changes in arctic air and soil temperatures, precipitation patterns and vegetation cover will result in complex interactions among controlling processes generating considerable uncertainty in estimating the net feedbacks on the climate system (ACIA, 2004).

As temperatures rise and permafrost degrades there could be an increase in active layer depth. This could lead to greater $\mathrm{CO}_{2}$ losses with increasing temperature leading to increased microbial activity and as previously frozen soil organic carbon becomes newly exposed to decomposition (Weller et al., 1995; Dutta et al., 2006; Schuur et al., 2008). Wet sites have a larger potential for changes in soil respiration rates under changing environmental conditions, compared to drier sites (Sommerkorn, 2008). Decomposition rates are expected to increase rapidly in wet environments if soils thaw and evaporation rates increase thereby lowering the water table resulting in aerobic conditions (Rodionow et al., 2006). As GEP and ER rates in many tundra vegetation communities are found to be moisture limited (Sjögersten et al., 2006), the response of increasing or decreasing moisture status could have a large impact on the carbon balance. Already we presume that the shrub site was a more mesic zone at one time, as this site has a surface layer of 
dry peat indicating that in the past this area had cool and wet conditions favoured peat accumulation. The high ER may be due to enhanced decomposition of this carbon substrate made possibly by higher temperatures and decreased VWC than what was present in the past.

Increasing air temperatures may also stimulate plant growth through longer growing seasons and an increase in nutrient cycling. This will cause gradual shifts in ecosystem structure and function altering the distribution of vegetation communities throughout the landscape (Chapin et al., 1995). This is particularly true for shrubs, which have increased in abundance in the low arctic landscape (Sturm et al., 2005). Increases in GEP may compensate for ER losses and strengthen growing season carbon accumulation. Warming experiments throughout the arctic examining the changes to the carbon cycle have displayed a variety of inconsistent results largely depending on ecosystem type (Rustad et al., 2001; Oechel et al., 2000; Oberbauer et al., 2007).

In order to better estimate how climate change will alter the carbon balance of arctic landscapes, modeling studies must account for landscape heterogeneity as warming will cause ecosystem specific changes in component carbon cycling processes. By identifying the current in situ driving controls on $\mathrm{CO}_{2}$ and $\mathrm{CH}_{4}$ exchange among vegetation communities in arctic landscapes, improved estimates of the impacts of climate change on the arctic carbon balance can be made. 


\subsection{Conclusion}

This study shows a high degree of spatial and temporal variability in $\mathrm{CO}_{2}$ and $\mathrm{CH}_{4}$ flux among and within vegetation community plots across a low arctic tundra landscape. There was a large control of hydrology on spatial and temporal variability in $\mathrm{CO}_{2}$ and $\mathrm{CH}_{4}$ exchange. Both field measurements and model parameters were used to examine of NEE, GEP and ER among sites. Variations among field measurements suggest ER is just as variable as GEP. Model parameters, which describe inherent differences due to plant species and microbial process, suggest GEP is inherently more variable. The photosynthetic capacity of plant functional types explained the variability in uptake rates. The spatial variability of $\mathrm{CH}_{4}$ flux is particularly high, due to strong controls of topography and associated hydrology. Overall, the magnitude and seasonality of $\mathrm{CO}_{2}$ and $\mathrm{CH}_{4}$ flux within the six arctic tundra ecosystems studied is in large agreement with similar tundra sites across the arctic.

Two micrometerological towers have been measuring NEE fluxes at Daring Lake, N.W.T, one situated in an upland area and the other located at a fen site. This study aids in the interpretation of larger scale carbon exchange by identifying how environmental variables control rates of GEP and ER among the main vegetation communities in this low arctic landscape. ER rates were quite similar among sites with contrasting hydrology. Only at the shrub site was ER significantly different due to the higher turnover rate of soil carbon at this vegetation community as a result of both relatively labile carbon substrate and high temperatures. 


\section{Subsurface Concentrations of Carbon Dioxide and Methane from Vegetation Community Plots in the Southern Canadian Arctic}

\subsection{Introduction}

Research examining the surface-atmosphere exchange of carbon dioxide $\left(\mathrm{CO}_{2}\right)$ and methane $\left(\mathrm{CH}_{4}\right)$ often focuses on measurements using chambers and micrometerological methods. Through this research various controls on $\mathrm{CO}_{2}$ and $\mathrm{CH}_{4}$ exchange have been identified, yet a large amount of spatial and temporal variability remains unexplained. Assessment of the controls on surface exchange may be enhanced by examining the controls on concentrations of $\mathrm{CO}_{2}$ and $\mathrm{CH}_{4}$ throughout the soil profile. Soil profile concentrations are a function of ecosystem processes including production, transformations and transport through the soil to the atmosphere and the conditions affecting these processes. These conditions are highly variable through both space and time and depend on ecosystem type.

The production of $\mathrm{CO}_{2}$ and $\mathrm{CH}_{4}$ is influenced by a multitude of abiotic and biotic factors including temperature, moisture content, active layer depth, water table position, precipitation, microtopography and plant species and productivity (Christensen $e t$ al., 2000; Blodau, 2002; Risk et al., 2002; Sommerkorn, 2008; Lai, 2009). Production of $\mathrm{CO}_{2}$ and $\mathrm{CH}_{4}$ throughout the soil profile results in subsurface concentrations that are much higher than atmospheric concentrations, producing concentration gradients that drive diffusive flux from the soil to the atmosphere. In unsaturated zones, gas transport is controlled by diffusion throughout the soil matrix, as a function of texture, porosity and soil water content and as a function of the magnitude of the vertical gradient in gas 
concentration (Whalen \& Reeburgh, 1990; Elberling et al., 2004; Luo \& Zhou, 2006). Transport of soil gases is also controlled by atmospheric turbulence. With more turbulent mixing in the atmosphere, the near surface concentration of trace atmospheric gases is reduced, increasing the concentration gradient between below and above ground and thereby increasing fluxes (Lafleur, 2009). Soil gases tend to accumulate near the surface in the evening when wind speed is low and are released in the morning when wind speed increases (Hirsch et al., 2003).

Once $\mathrm{CH}_{4}$ is produced in an anaerobic zone it may become oxidized as it diffuses through an aerobic surface layer by methanotrophic bacteria before reaching the surface (Whalen \& Reeburgh, 1990). When the water table is near the surface the potential for $\mathrm{CH}_{4}$ oxidation is minimized allowing for large $\mathrm{CH}_{4}$ emissions.

In saturated zones diffusive flux is slow compared to two other transport mechanisms; ebullition and plant mediated transport (Lai, 2009). As dissolved concentrations of $\mathrm{CO}_{2}$ and $\mathrm{CH}_{4}$ increase beyond their equilibrium solubility, gas bubbles form (Kellner et al., 2005). These subsurface gas bubbles containing high concentrations of $\mathrm{CO}_{2}$ and $\mathrm{CH}_{4}$ may be episodically released to the atmosphere by triggers such as changes in barometric pressure and atmospheric turbulence (Tokida et al., 2007; Sachs et al., 2008). Vascular plants such as sedges, exchange trace gases between below ground and the atmosphere via aerenchyma tissue. Plant mediated transport may enable $\mathrm{CH}_{4}$ to bypass an aerobic oxidation zone, while transport of oxygen to the subsurface may lead to $\mathrm{CH}_{4}$ oxidation (Watson et al., 1997; Kutzbach et al., 2004). 
Research examining subsurface $\mathrm{CO}_{2}$ and $\mathrm{CH}_{4}$ concentrations in the arctic is necessary in order to gain a better understanding of controls on subsurface carbon cycling in arctic regions. Few arctic studies have examined production of $\mathrm{CO}_{2}$ and $\mathrm{CH}_{4}$ through the soil profile due to the difficulty of measuring soil subsurface concentrations, particularly in wet ecosystems (Joabsson \& Christensen, 2001; Elberling et al., 2004). However, due to the presence of continuous permafrost in arctic environments, profiles of $\mathrm{CO}_{2}$ and $\mathrm{CH}_{4}$ concentrations may differ significantly from those observed in more temperate climates.

This study attempts to examine the temporal and spatial variability of subsurface soil concentrations of $\mathrm{CO}_{2}$ and $\mathrm{CH}_{4}$ at six vegetation communities in the low arctic. The objectives of this study were to 1) to assess the temporal and spatial variability of subsurface $\mathrm{CO}_{2}$ and $\mathrm{CH}_{4}$ concentrations within and among different arctic tundra ecosystems 2) investigate the controls on these concentrations and 3) relate subsurface concentrations to surface flux measurements. 


\subsection{Materials \& Methods}

\subsubsection{Site Description}

This study took place during the 2008 growing season at the Tundra Ecological Research Station (TERS) at Daring Lake, Northwest Territories, Canada (64'52’ N, $\left.111^{\circ} 34^{\prime} \mathrm{W}\right)$. This site is located in the lower central Canadian arctic, approximately 75 $\mathrm{km}$ north east of the tree line. Research activities occurred in collaboration with the Canadian Tundra Ecosystem Carbon Study established in 2004 at Daring Lake (Lafleur \& Humphreys, 2008).

The climate in this area is characterized by long winters and short snow free growing seasons (mid June to early September). Mean annual temperature in the region is $-13^{\circ} \mathrm{C}$ and annual precipitation rages between $200-400 \mathrm{~mm}$ (Lafleur \& Humphreys, 2008). Soils of the research area formed from till and glaciofluvial materials causing soils to generally have a coarse texture with a high proportion of sand and a considerable amount of silt which makes them susceptible to cryoturbation (Tarnocai, 2004). The landscape is underlain with continuous permafrost with the active layer depth depending on growing season temperatures and topography, with a typical range of $0.3-1.2 \mathrm{~m}$ (Dredge et al., 1999). The active layer becomes saturated after spring thaw. Upland areas drain quickly while the combination of low evaporation rates and impeded drainage due to permafrost means much of the lowland areas are saturated throughout the growing season. Microtopography over centimetres to meters may occur due to hummocks and frost action in tussock tundra affecting the hydrologic regime. Dry upland zones have a 
thin A horizon $(2-10 \mathrm{~cm})$ while wetter areas have substantial peat accumulation $(30-70$ $\mathrm{cm})$.

Six vegetation communities were chosen to represent the variability of vegetation and microtopography across this low arctic landscape. Vegetation community plots included heath and shrub tundra, sedge tussock \& hollow and fen tussock and hollow. At both the sedge and fen areas tussocks and hollows were studied separately to examine the effects of microtopographical heterogeneity of wet arctic environments. A detailed description of the six sites can be found in Chapter 2.

\subsubsection{Subsurface Gas Samplers}

Two different types of subsurface soil gas samplers were created for use in dry and wet soil environments. At the drier environments, heath, shrub, sedge tussock and fen tussock, gas wells were constructed which allowed air from the soil matrix to diffuse through a moisture resistant Tyvec membrane. These wells were similar in design to those used in other studies in Acadian forest soil (Bekele et al., 2007; Risk et al., 2008). At the wet sedge hollow and fen hollow sites there was a high water table throughout the growing season. The gas wells would have filled with water in these wet environments. In order to sample gas concentrations we constructed silicone tubes similar to those used in other peatland studies (Goldberg et al., 2008; Knorr et al., in press). The use of silicone tubes for trace gas research is becoming more common due to both the low cost and effectiveness in the field (Kammann et al., 2001). The air volume within the silicone samplers, when surrounded by water created an in situ headspace effectively in equilibrium with pore water. This eliminates the need to collect water samples for 
transport to a laboratory where a headspace technique is commonly used to measure dissolved pore water concentrations (Joabsson \& Christensen, 2001; Wagner et al., 2003; Strack \& Waddington, 2008).

Gas wells for the drier soils were constructed of polyvinylchloride (PVC) tubes 12 $\mathrm{cm}$ in length with a $1.2 \mathrm{~cm}$ inner diameter and an internal volume of $13.6 \mathrm{~cm}^{3}$ (Figure 3.1). Small holes were drilled along the tube and then covered with Tyvec (DuPont, Wilmington, DE USA), a water resistant membrane which allows air from the air filled pore space to diffuse into the sampler. Tubes were capped at both ends and two holes were drilled into the tube to fit Bev-a-Line (Cole Parmer, USA) polyethylene tubing (inner diameter $3 \mathrm{~mm}$ ) into the sampler. The tubing was sealed onto the tube with silicone caulking. Luer fittings and 3-way stopcocks were installed at the ends.

In the summer of 2007 soil pits were dug at the heath and shrub site and dry subsurface soil gas wells were installed horizontally into pit walls. At each site 3 profiles of samplers were installed at depths of $5,10,20,40,60 \mathrm{~cm}$. Once installed the pits were carefully refilled replacing soil layers in the same order as they were dug out. At the sedge tussocks and fen tussocks subsurface soil gas wells were installed into peat at 5 and $10 \mathrm{~cm}$ depths and the moss was then stapled to return tussocks to their original structure. All tubing was routed to the surface and attached to a wooden post. The gas wells were left until the following field season to equilibrate with the surrounding environment. Gas samples were taken by first withdrawing $10 \mathrm{ml}$ of air volume to clear the air within the Bev-a-Line connecting tubing. Then $24 \mathrm{ml}$ of air was withdrawn and injected into $12 \mathrm{ml}$ pre-evacuated glass vials (Exetainer, Labco Inc., England). The stopcocks were then shut 

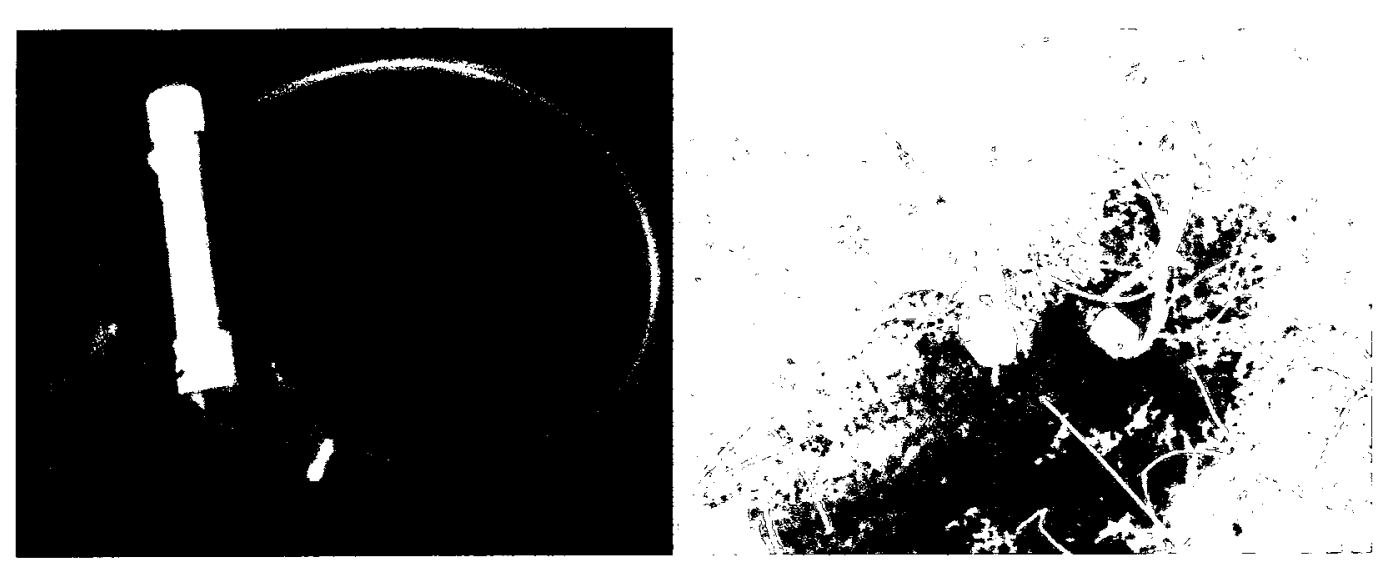

Figure 3.1: Gas well for unsaturated soil (left). The installation of gas wells at 5 and 10 $\mathrm{cm}$ below the surface of a tussock (right). 
at the surface and air from the soil matrix would refill the samplers. There was a 4 to 5 day time period between measurements so that air within the samplers would return to equilibrium with the surrounding soil environment.

The gas samplers for saturated soils were constructed from polyvinylchloride (PVC) pipes wrapped with silicone tubing in $10 \mathrm{~cm}$ intervals from $0-60 \mathrm{~cm}$ (Figure 3.2). Silicone tubing had a length of $150 \mathrm{~cm}$ and an internal volume of $34.4 \mathrm{~cm}^{3}$. One side of the tubing was sealed with silicone caulking, and the other attached with luer fittings with double hose barbs to gas impermeable Bev-a-Line polyethylene tubing with a length of $200 \mathrm{~cm}$ and internal volume of $15.8 \mathrm{~cm}^{3}$. The polyethylene tubing was fed inside the pipe through a drilled hole and connected to a 3-way stopcock above the surface.

During the 2008 field season 3 silicone tube profile samplers were installed at the wet sedge hollow and fen hollow plots. An auger was used to first create a vertical hole in the peat profile. The hole was a bit smaller than the pipe diameter so that it would fit snug in the peat profile. Since these sites were saturated for most of the field season vertical installation did not allow for mass flow along the soil pit. During sampling, $24 \mathrm{ml}$ of air was withdrawn from each silicone tube and injected into a pre-evacuated $12 \mathrm{ml}$ preevacuated glass vials. The tubing was then left open to allow ambient air to return the internal volume in the silicone tube to normal pressure conditions. As the active layer thickened tubes were pushed deeper into the subsurface to sample newly thawed peat. To allow for equilibrium to be reached between the air in the internal silicone tubing and the outside peat environment there was a 4 to 5 day time period between sampling 


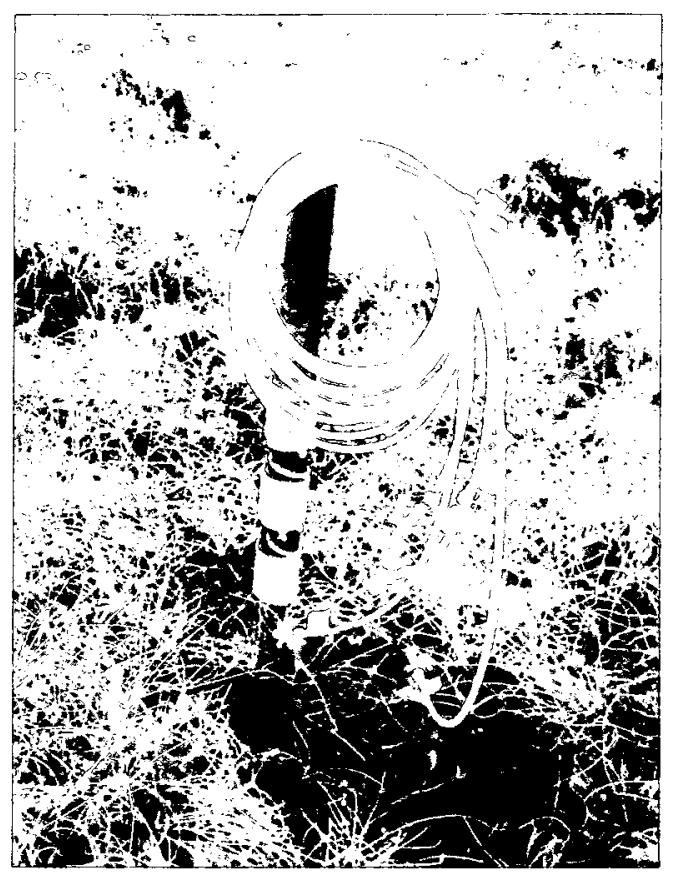

Figure 3.2: Gas sampler for saturated soils at the fen hollow site. 
measurements Equilibrium time for similar silicone tubing has been in the range of hours to days (Jacinthe \& Groffman, 2001).

\subsubsection{Surface Flux Measurements}

Opaque static chambers were used to measure $\mathrm{CO}_{2}$ efflux and $\mathrm{CH}_{4}$ flux at four permanent collars near the subsurface gas samplers. Measurements were taken at the same time as subsurface concentration measurements, as well as in the days between subsurface measurements for a total of 19 days throughout the growing season. A more detailed description of chamber flux methods can be found in Chapter 2 .

\subsubsection{Environmental Measurements}

Soil temperatures were measured manually with copper-constantan thermocouples installed next to subsurface samplers. These were installed at $5,10,20,40,60 \mathrm{~cm}$ at the heath and shrub sites, 5 , and $10 \mathrm{~cm}$ at the sedge tussock and hollow sites and every $10 \mathrm{~cm}$ at the sedge hollow and fen hollow (as active layer deepened additional thermocouples were measured). Temperature was also manually measured at 3,6 and $9 \mathrm{~cm}$ depths with themister probes (TD32, Omega, Stanford, CT, USA).

Volumetric water content (VWC) $\left(\mathrm{m}^{3} \mathrm{~m}^{-3}\right)$ was recorded by vertically inserting a $20 \mathrm{~cm}$ probe from the soil surface (Hydrosense, Campbell Scientific Inc., Logan, UT, USA). Hydrosense VWC values were not calibrated to the specific soils and as a result provide a better idea of relative differences in VWC through time and spatially than absolute VWC. A soil moisture profile was also continuously measured at each vegetation community site with averages recorded every hour during the field season. 
Moisture probes (EC-5 $\mathrm{H}_{2} \mathrm{O}$ Soil Moisture Sensors, Decagon Devices, Inc.) were installed at depths of $0,5,10,20$ and $40 \mathrm{~cm}$ at the heath and shrub sites. Probes were installed at depths of $0,5,10$ and $20 \mathrm{~cm}$ in the tussocks and at $0 \mathrm{~cm}$ in the hollows at the sedge and fen sites. At all sites the $0 \mathrm{~cm}$ depth was just beneath the litter layer. As $5 \mathrm{~cm}$ depth measurements were not taken at the sedge and fen hollow sites, the corresponding fen tussock measurements at $20 \mathrm{~cm}$ depth (which corresponded to the $5 \mathrm{~cm}$ depth at the fen hollows, as the fen tussock with the moisture probes profile was $\sim 15 \mathrm{~cm}$ above the average hollow surface) was used to approximate $5 \mathrm{~cm}$ depth at the hollows. Peat VWC measurements were adjusted with calibration relationships derived in the laboratory. Standard calibrations from the manufacturer were used for the probes installed in mineral soils.

Soil samples from the heath and shrub sites were collected from the pits dug during installation of the tyvec gas wells in 2007 . Samples were taken using a $0.05 \mathrm{~cm}^{3}$ soil core within each pit at a $3 \mathrm{~cm}$ interval to $10 \mathrm{~cm}$ and at a $10 \mathrm{~cm}$ interval below this depth. Peat samples at the sedge and fen tussocks were collected in 2007, while in 2006 fen profiles were collected. At the sedge and fen sites, peat "bricks" were pulled out and sectioned into subsamples of $0.125 \mathrm{~cm}^{3}$. Bulk density was determined by drying mineral samples at $110^{\circ} \mathrm{C}$ and peat samples at $80^{\circ} \mathrm{C}$ for at least $24 \mathrm{hrs}$ and dividing this weight by the volume of the sample. Organic matter content for the heath and shrub sites was measured using the loss on ignition method with a Muffle Furnace (Fisher Scientific Isotemp Programmable). Subsamples of dried homogenized soil were heated to $550^{\circ} \mathrm{C}$ for $4 \mathrm{hrs}$ to ignite the organic matter. Peat samples were assumed to be $100 \%$ organic matter. 
Carbon content was determined to be $52 \%$ of organic matter on a mass basis as determined by a LECO analyzer. The carbon content of each depth was then determined on a volume basis using the sample bulk density. Average organic matter content on an area basis was calculated by integrating the carbon content along the soil profile. Soil texture was determined using a modified standard sedimentation technique (Kemper \& Rosenau, 1986). Thaw depth was recorded weekly by recording the maximum depth a steel rod could be inserted into the soil to the permafrost surface at 10 locations within each vegetation community site. Climate data, including precipitation, air temperature and friction velocity was measured at a nearby meteorological tower (Lafleur \& Humphreys, 2008).

\subsection{5. $\mathrm{CO}_{2}$ and $\mathrm{CH}_{4}$ Concentration Calculations}

Exetainer vials, covered with silicone and rubber septum, were transported to Carleton University Biometeorology laboratory where $\mathrm{CO}_{2}$ and $\mathrm{CH}_{4}$ concentrations in unit of part per million volume (ppmv) were obtained with a gas chromatograph (CP 3800, Varian, CA, USA) equipped with a flame-ionization detector (FID) and methanizer operated at $300^{\circ} \mathrm{C}$ and $350^{\circ} \mathrm{C}$, respectively using a He carrier gas at $30 \mathrm{ml} \mathrm{min}^{-1}$. Gas separation was obtained using a Haysep N 80/100 pre-column $(0.32 \mathrm{~cm}$ diam. $x 50 \mathrm{~cm}$ length) and Poropak QS 80/100 mesh analytical columns $(0.32 \mathrm{~cm}$ diam. $\times 200 \mathrm{~cm}$ length) in column oven maintained at $50^{\circ} \mathrm{C}$. At least 3 replicates of five standards ranging from 439.2 and $15212.6 \mathrm{ppm} \mathrm{CO}_{2}$ and 1.08 and $19.94 \mathrm{ppm} \mathrm{CH}_{4}$ and $\mathrm{He}$ blanks were included in every gas sampling event to maintain quality control and establish the linear relationship between chromatogram area and gas concentrations. 
Concentrations of $\mathrm{CO}_{2}$ and $\mathrm{CH}_{4}$ from the samplers at the heath, shrub, and sedge and fen tussocks represent concentrations from the air filled pore space. Conversion from ppmv to $\mu \mathrm{mol} \mathrm{Lg}_{\mathrm{g}}^{-1}$ of air was done using the ideal gas law with barometric pressure measured at the tower and the nearest soil temperature reading.

At the sedge and fen hollows VWC was high and therefore the portion of air and water filled pore space needed to be determined in order to determine contribution of $\mathrm{CO}_{2}$ and $\mathrm{CH}_{4}$ in the silicone tubes from the gas and dissolved phase. The water filled pore space was calculated using VWC measurements and porosity, as determined from bulk density measurements and assuming a peat particle density of $1.4 \mathrm{~g} \mathrm{~cm}^{-3}$ (King \& Smith, 1987). When water filled pore space was high the volume within the silicone samplers is similar to an in situ headspace, gas concentrations must be converted into dissolved gas concentrations by using Henry's law. The Henry coefficients for $\mathrm{CO}_{2}$ and $\mathrm{CH}_{4}$ have to be recalculated for the in situ temperature at each depth. Henry's coefficients are determined using Equation 3.1 where $K_{H}$ is Henry's coefficient in mol L $\mathrm{L}^{-1} \mathrm{~atm}^{-1}, \mathrm{~K}_{\mathrm{H}}^{\theta}$ is the Henry coefficient at standard conditions, $\mathrm{T}$ is temperature in Kelvin, and $\mathrm{T}^{\boldsymbol{\theta}}$ is standard temperature $\left(298.15 \mathrm{~K}\right.$ ) (Sander, 1999). Concentrations of dissolved $\mathrm{CH}_{4}$ and $\mathrm{CO}_{2}$ are determined using Equations 3.2 and 3.3 respectively. Example conversions can be found in Appendix 1. Dissolved inorganic carbon (DIC) speciation was calculated using average pore water $\mathrm{pH}$ (sedge $\mathrm{pH} 5.2$, fen $\mathrm{pH} 4.7$ ) as seen in Equation 3.3 where $\mathrm{pKa}$ is the acid dissociation constant of carbonic acid (6.4). Dissolved concentrations are in units of $\mu \mathrm{mol} \mathrm{L} \mathrm{L}^{-1}$. As the water table never went $12 \mathrm{~cm}$ below the moss surface at the fen, only the concentrations from the silicone tubing of the $0-10 \mathrm{~cm}$ interval were divided up into 
$\mathrm{CO}_{2}$ and $\mathrm{CH}_{4}$ concentrations from the gas and dissolved phase. Below this depth it was assumed that peat was fully saturated.

$$
\begin{aligned}
& K_{H}=K_{H}^{\oplus} \exp \left(\frac{d \ln K}{d \frac{1}{T}}\right)\left(\frac{1}{T}-\frac{1}{T^{0}}\right)
\end{aligned}
$$

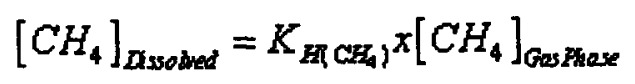

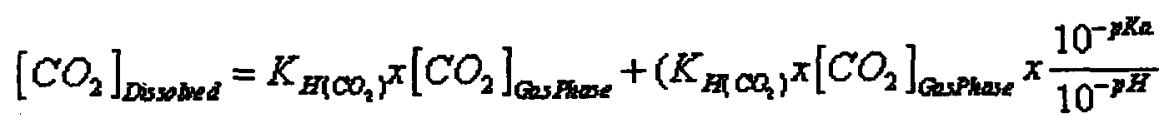




\subsection{Results}

\subsubsection{Site Characteristics}

Soil characteristics are important determinants of both $\mathrm{CO}_{2}$ and $\mathrm{CH}_{4}$ production and transport. The soil characteristics of the six vegetation communities are listed in Table 3.1. The two drier sites, heath and shrub had coarse soil textures (sand and loamy sand respectively). Both had shallow organic layers with organic matter content at the shrub site greater than the heath site. The wetter sites, sedge $\&$ fen (tussock and hollow) both had substantial peat accumulation over loamy sand (sedge) or silt loam (fen).

Profiles of soil organic carbon show distinct differences between the wet and dry sites (Figure 3.3). Carbon content decreased with depth at the heath and shrub sites and increased with depth at the sedge tussock and fen tussock and hollow sites. As the sedge and fen sites are peat to at least $60 \mathrm{~cm}$, the increase with depth is the result of an increase in peat bulk density through the profile.

Large precipitation events increased in occurrence from August $5^{\text {th }}$ (DOY 218) to the end of the study period resulting in increasing VWC at all sites (Figure $3.4 \&$ Figure 3.5). The water table at the fen site decreased below the moss surface though July until August $5^{\text {th }}$ (DOY 218) and then rose substantially thereafter and remained above the moss surface after August 15 $5^{\text {th }}$ (DOY 228) (Figure 3.4). Average daily soil and air temperatures fluctuated throughout the field season with peak maximum daily temperatures occurring mid July to mid August ( $\sim$ DOY 198-223) and then decreasing thereafter (Figure 3.4). Friction velocity was greatest during the daytime and both 
Table 3.1: Soil characteristics of the six vegetation communities at Daring Lake, N.W.T. Values in brackets indicate \pm 1 standard error of the mean. Texture and organic matter content were not assessed separately for tussocks and hollows. The depth of organic matter at the sedge and fen tussocks is an estimate given the depth at the hollows plus an average 10 and $20 \mathrm{~cm}$ height of tussocks respectively.

\begin{tabular}{lllllll}
\hline & Heath & Shrub & $\begin{array}{l}\text { Sedge } \\
\text { Tussock }\end{array}$ & $\begin{array}{l}\text { Sedge } \\
\text { Hollow }\end{array}$ & $\begin{array}{l}\text { Fen } \\
\text { Tussock }\end{array}$ & $\begin{array}{l}\text { Fen } \\
\text { Hollow }\end{array}$ \\
\hline Soil Texture & Sand & Loamy Sand & Peat over Loamy Sand & Peat over Silt Loam \\
\hline $\begin{array}{l}\text { Depth of organic layer } \\
\text { (cm) }\end{array}$ & $2-5$ & $0-10$ & $40-60$ & $20-40$ & $50-60$ & $40-50$ \\
\hline $\begin{array}{l}\text { Average Organic Matter } \\
\text { Content 0-25 cm depth } \\
\left(\mathrm{kg} \mathrm{m}^{-2}\right)\end{array}$ & $8.45(0.97)$ & $12.86(2.66)$ & $23.54(4.27)$ & & $21.56(1.26)$ \\
\hline
\end{tabular}


daytime and night time average friction velocities fluctuated considerably throughout the season (Figure 3.4).

Soil volumetric water content varied among sites (Figure 3.5). The heath site had low VWC which increased with depth. The shrub site had much lower VWC near the surface and large variation at $40 \mathrm{~cm}$ depth in July, possibly coinciding with melting ice and lateral flow near this depth, as the average thaw depth was 42 to $68 \mathrm{~cm}$ from July $4^{\text {th }}$ to $22^{\text {nd }}$ (DOY 186-204). The sedge and fen hollows had the highest VWC, followed by the fen tussock and then the sedge tussock sites. Lower VWC values at $0 \mathrm{~cm}$ at the fen hollow may be due to a localized drier zone. VWC at $20 \mathrm{~cm}$ depth was lower in the sedge versus fen tussock because tussocks at the sedge site were around $20 \mathrm{~cm}$ in height while the fen tussocks were generally $10 \mathrm{~cm}$ in height. Therefore at $20 \mathrm{~cm}$ depth in the fen the VWC probes were in saturated conditions. At all sites VWC increased substantially in August due to large precipitation events (Figure 3.5). 


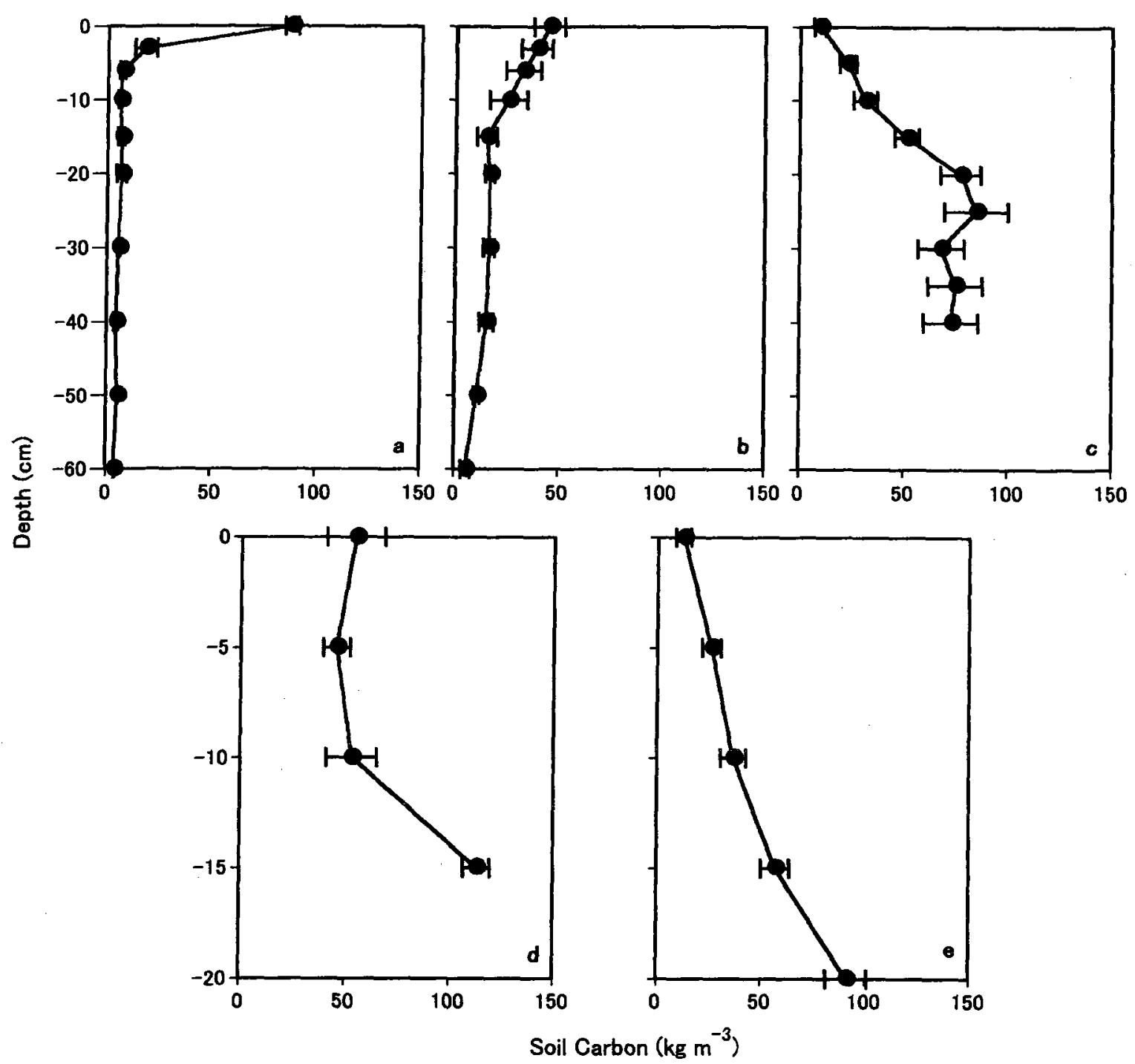

Figure 3.3: Soil organic carbon $\left(\mathrm{kg} \mathrm{m}^{-3}\right)$ measurements from (a) heath, (b) shrub, (c) fen hollow, (d) sedge tussock and (e) fen tussock sites. The litter to soil interface is located at $0 \mathrm{~cm}$. Values are means \pm 1 standard error of the mean. 

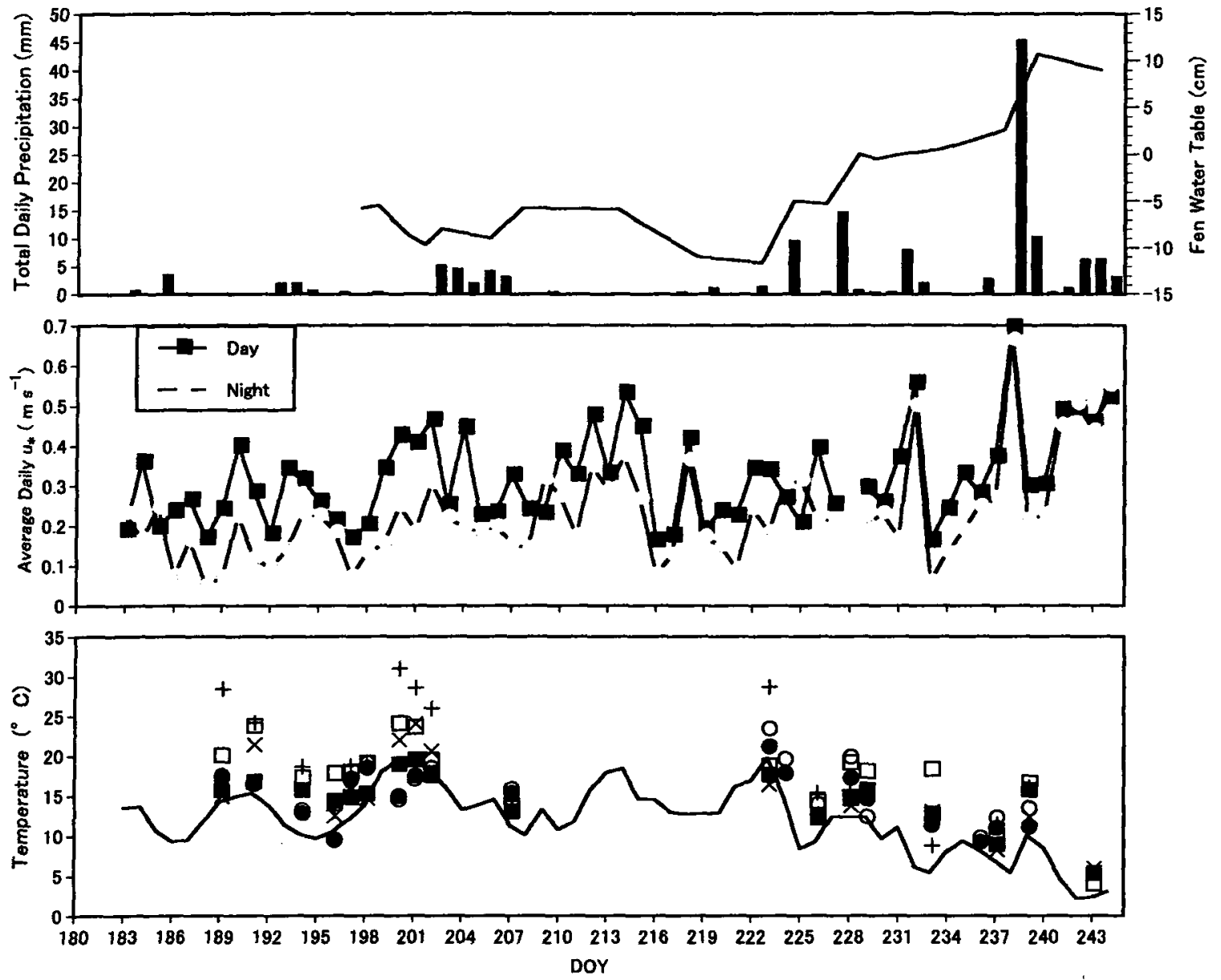

$\times$ Heath + Shrub $\square$ Sedge Tussock Sedge Hollow $\square$ Fen Tussock Fen Hollow

Figure 3.4: Total daily precipitation $(\mathrm{mm})$, water table in reference to moss surface at the fen site $(\mathrm{cm})$, average daily $\mathrm{u} *$ (friction velocity) $\left(\mathrm{m} \mathrm{s}^{-1}\right)$ for day (solar radiation is greater than $10 \mathrm{~W} \mathrm{~m}^{-2}$ ) and night time periods, average soil temperature $\left({ }^{\circ} \mathrm{C}\right)$ at $3 \mathrm{~cm}$ depth at the six vegetation communities and average daily air temperature $\left({ }^{\circ} \mathrm{C}\right)$ at $1.5 \mathrm{~m}$ above the ground surface (solid line). Soil temperature values are means. Error bars are not shown for clarity. Std error for soil temperature was on average $0.8^{\circ} \mathrm{C}$ but as large as $3.4^{\circ} \mathrm{C}$ 

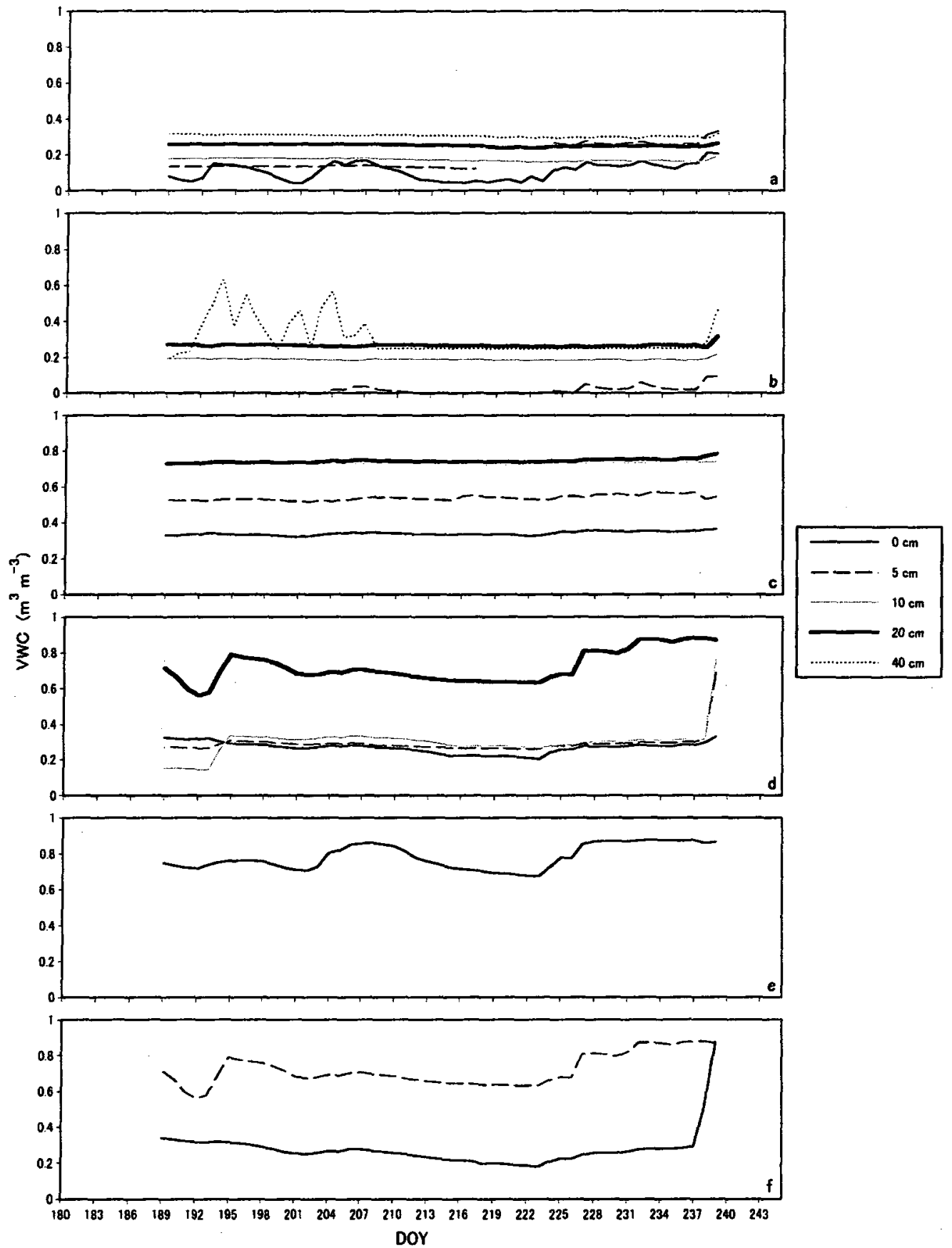

Figure 3.5: Average daily volumetric water content (VWC, $\mathrm{m}^{3} \mathrm{~m}^{-3}$ ) at the a) heath, b) shrub, c) sedge tussock, d) fen tussock, e) sedge hollow and f) fen hollow during the 2008 field season. 


\subsubsection{Subsurface $\mathrm{CO}_{2}$ and $\mathrm{CH}_{4}$ Concentrations}

\section{Heath \& Shrub}

At the dry heath and shrub sites, $\mathrm{CO}_{2}$ concentrations generally increased with depth and decreased at all depths through the month of August (DOY 214-244) (Figure 3.6 \& Figure 3.7). At the beginning of July (DOY 189, 196) the shrub site had higher $\mathrm{CO}_{2}$ concentrations at $40 \mathrm{~cm}$ depth than the heath site (Figure 3.7). Subsurface concentrations of $\mathrm{CH}_{4}$ were generally lower than atmospheric concentrations $(\sim 1.8-2.0$ ppmv or $\sim 0.07-0.08 \mu \mathrm{mol} \mathrm{Lg}{ }^{-1}$ ), with the highest concentrations near the surface and decreasing with depth (Figure 3.6 \& Figure 3.8). However, at the $60 \mathrm{~cm}$ depth high $\mathrm{CH}_{4}$ concentrations occurred on DOY 189 at both the heath and shrub sites (Figure 3.8). On this day temperatures at $60 \mathrm{~cm}$ were close to $0^{\circ} \mathrm{C}$ and the average active layer depth on DOY 186 was 37 and $42.1 \mathrm{~cm}$ for the heath and shrub site respectively which could have resulted in localized zones of saturation just above the underlying frozen soil due to restricted drainage. Consequently, anaerobic conditions could have temporarily existed at this depth and resulted in $\mathrm{CH}_{4}$ production and relatively high $\mathrm{CH}_{4}$ concentrations. Spikes in $\mathrm{CH}_{4}$ concentration at 5 and $10 \mathrm{~cm}$ depth occurred after large precipitation events and increasing VWC creating localized and short-lived anaerobic conditions (Figure 3.4, Figure 3.5 \& Figure 3.8). This occurred most at the shrub site. Additionally, most days when increased $\mathrm{CH}_{4}$ concentrations occurred in both shallow and deep depths, we found bursts of $\mathrm{CH}_{4}$ concentration in chambers at these drier vegetation communities. This indicates that $\mathrm{CH}_{4}$ produced at deeper depths in temporary anaerobic environments is not fully oxidized before being released to the atmosphere. Sporadic emissions of $\mathrm{CH}_{4}$ have 


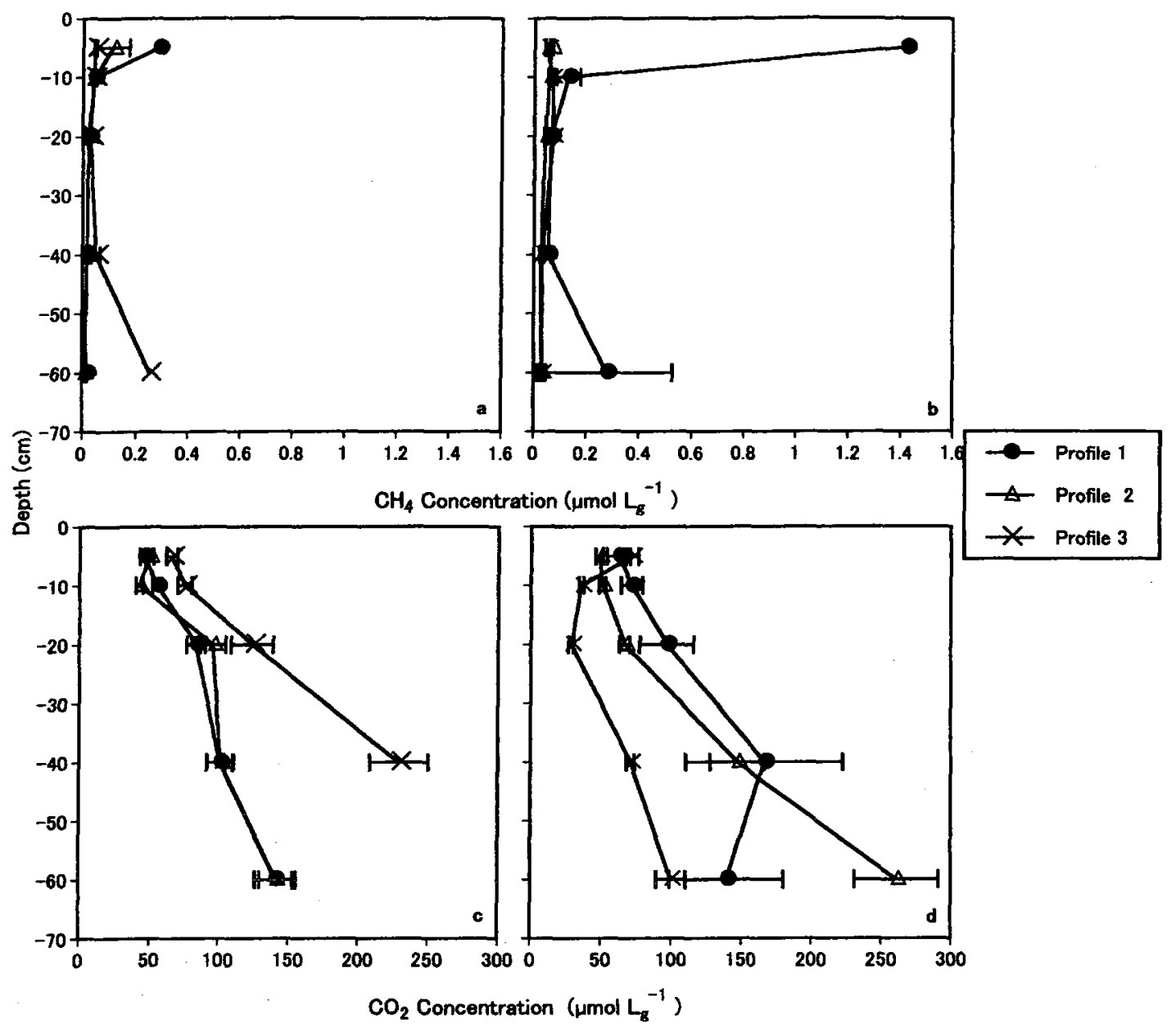

Figure 3.6: Average seasonal subsurface $\mathrm{CH}_{4}$ concentration $\left(\mu \mathrm{mol} \mathrm{L} \mathrm{L}^{-1}\right)$ profiles for the a) heath and b) shrub site and $\mathrm{CO}_{2}$ concentration $\left(\mu \mathrm{mol} \mathrm{L}_{\mathrm{g}}{ }^{-1}\right)$ profiles for the c) heath and d) shrub site. Values are means \pm 1 standard error (SE) of the mean. Error bars are removed from profile $1 \mathrm{CH}_{4}$ concentrations at $5 \mathrm{~cm}$ for both the heath ( $\mathrm{SE}=0.23 \mu \mathrm{mol}$ $\left.\mathrm{L}_{\mathrm{g}}^{-1}\right)$ and shrub ( $\left.\mathrm{SE}=0.86 \mu \mathrm{mol} \mathrm{L}_{\mathrm{g}}^{-1}\right)$ sites for visual clarity. 


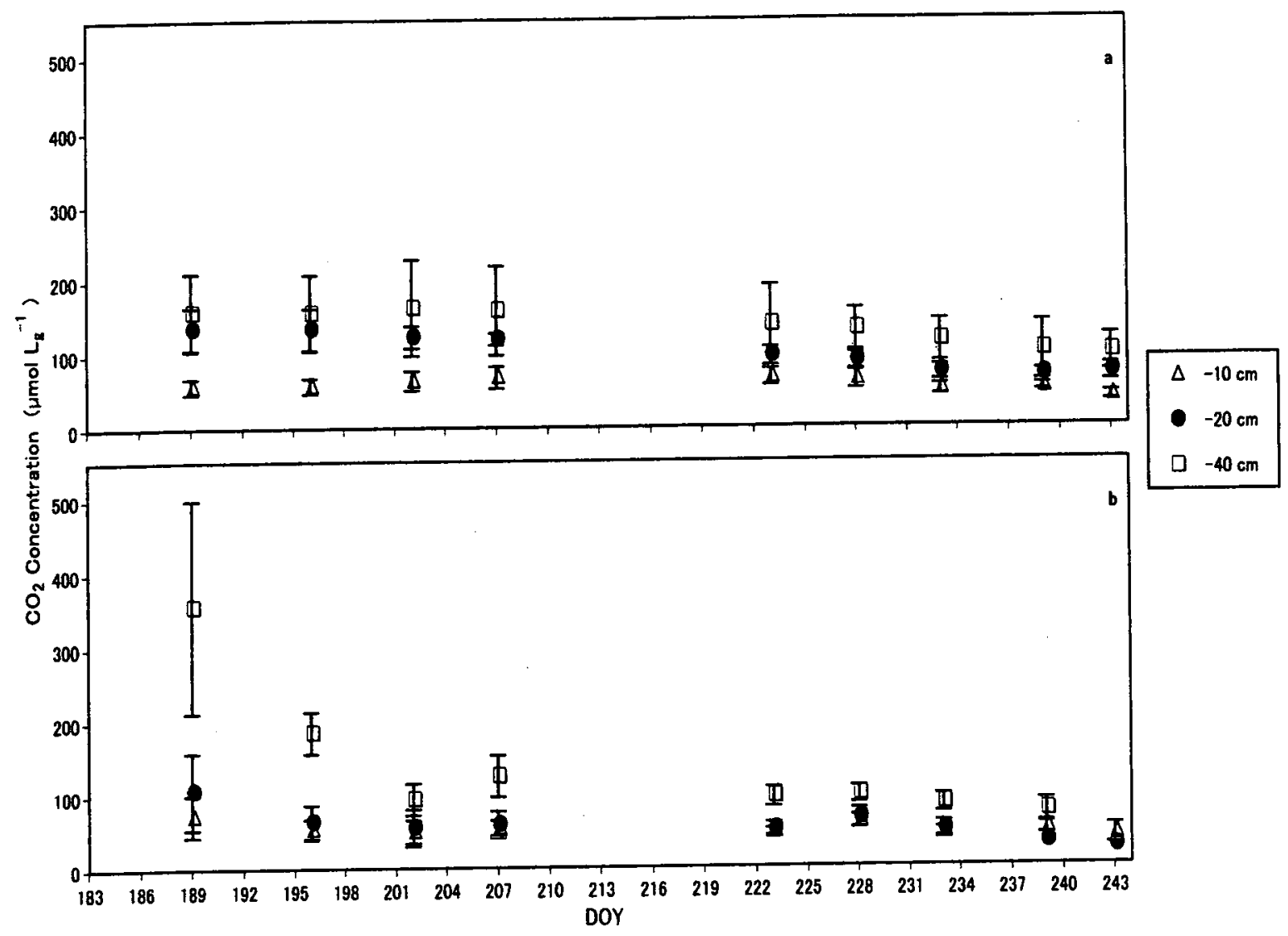

Figure 3.7: Subsurface $\mathrm{CO}_{2}$ concentration $\left(\mu \mathrm{mol} \mathrm{L}{ }_{\mathrm{g}}^{-1}\right.$ ) profiles for the a) heath and b) shrub site at 10,20 and $40 \mathrm{~cm}$ depth. Values are means \pm 1 standard error of the mean. 


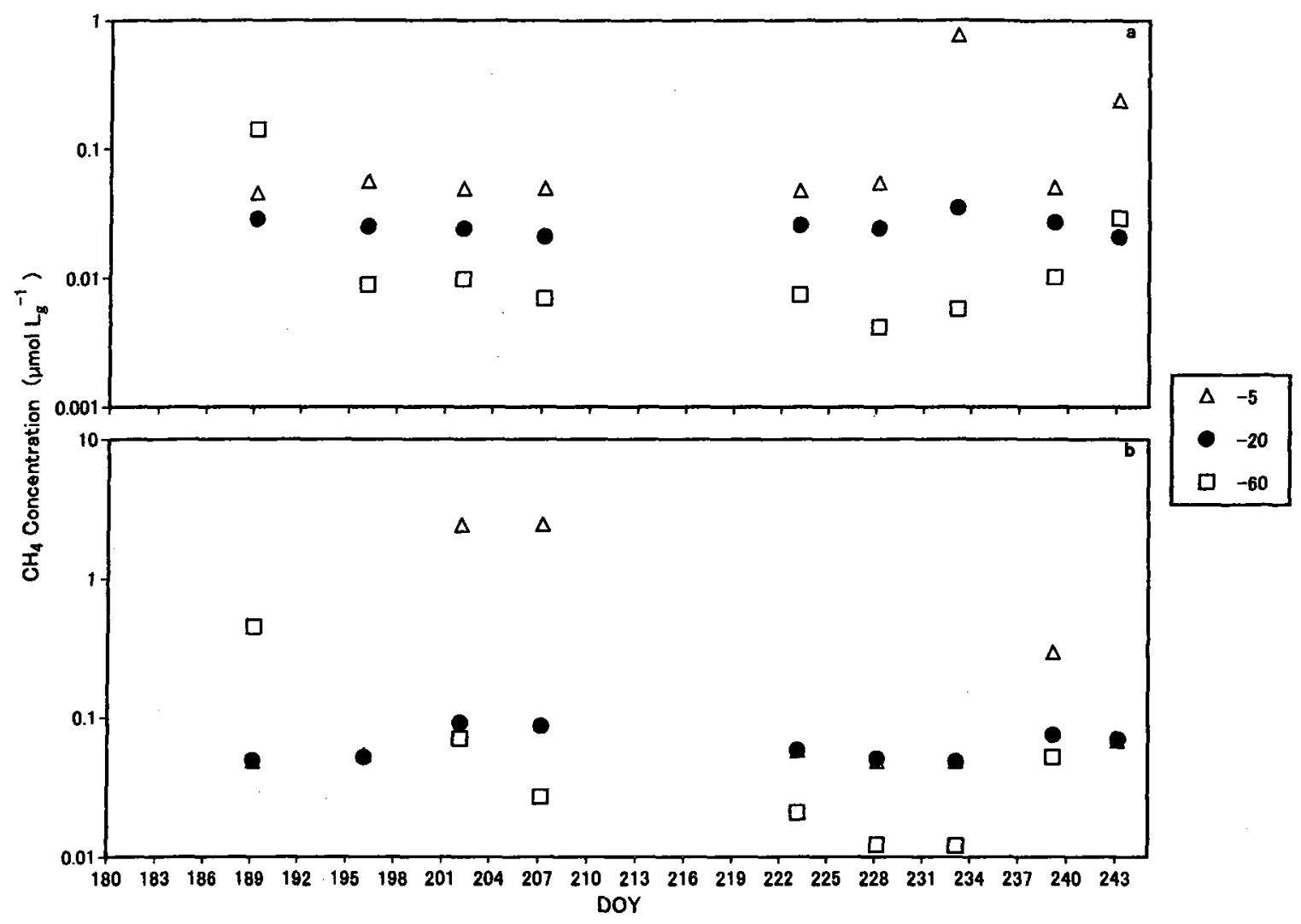

Figure 3.8: Subsurface $\mathrm{CH}_{4}$ concentration $\left(\mu \mathrm{mol} \mathrm{Lg}{ }^{-1}\right.$ ) profiles (in logarithmic scale) for the a) heath and b) shrub site at 5,20 and $60 \mathrm{~cm}$ depth. Error bars are not shown for clarity. Standard error was on average $0.14 \mu \mathrm{mol} \mathrm{L}_{\mathrm{g}}^{-1}$ but as large as $2.28 \mu \mathrm{mol} \mathrm{L}_{\mathrm{g}}^{-1}$. 
also been seen at a forest-tundra ecotone in northern Norway where authors suggested that emissions were likely the result of water logging due to the presence of ground ice which impeded drainage (Sjögersten \& Wookey, 2002). A seasonal trend in $\mathrm{CH}_{4}$ concentrations was not found (Figure 3.8).

\section{Sedge $\&$ Fen Tussocks}

Within the waterlogged sedge and fen sites, tussocks were zones of low density peat and living moss located above the water table for most of the season creating zones of aeration within these wet areas. Spatial and temporal variability of both $\mathrm{CO}_{2}$ and $\mathrm{CH}_{4}$ concentrations was high (Figure 3.9 \& Figure 3.10). Concentrations of $\mathrm{CH}_{4}$ and $\mathrm{CO}_{2}$ were higher at $5 \mathrm{~cm}$ than at $10 \mathrm{~cm}$ at some profile locations and during most but not all sampling days (Figure 3.10). Upon further investigation it was discovered that high $\mathrm{CH}_{4}$ concentrations ( $>5 \mu \mathrm{mol} \mathrm{L}^{-1}$ ) at $5 \mathrm{~cm}$ usually occurred after large rain events (ex: DOY $196,207,228 \& 233$ ) except on DOY 239 when there was a $45 \mathrm{~mm}$ rainfall the previous day but average daily $\mathrm{u} *$ was also high $\left(>0.7 \mathrm{~m} \mathrm{~s}^{-1}\right)$ leading to flushing of $\mathrm{CH}_{4}$ out of the aerated tussocks (Figure $3.4 \&$ Figure 3.10 ). 


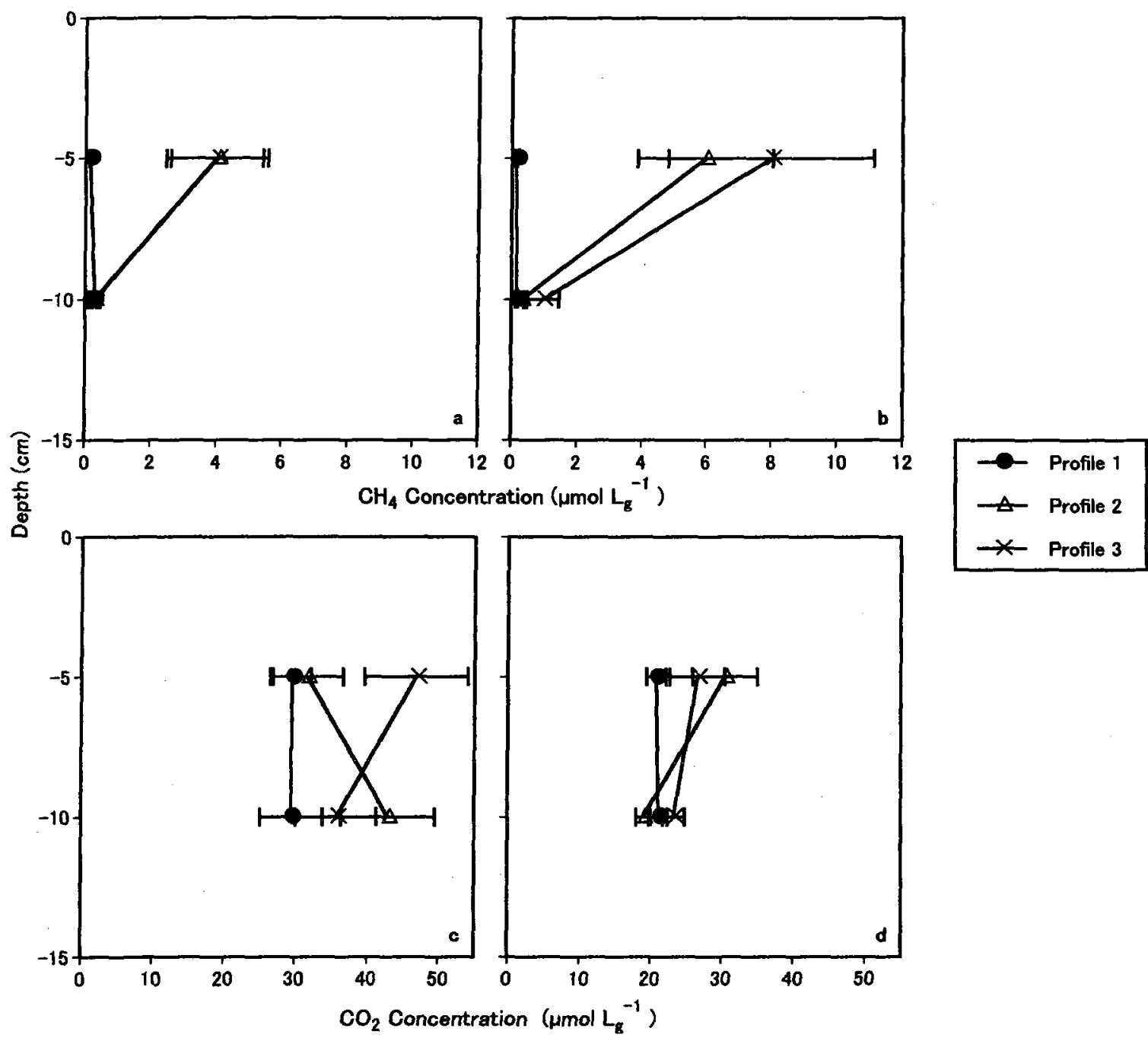

Figure 3.9: Average seasonal subsurface $\mathrm{CH}_{4}$ concentration profiles for the a) sedge tussock and b) fen tussock site and $\mathrm{CO}_{2}$ concentration profiles for the c) sedge tussock and d) fen tussock. Values are means \pm 1 standard error of the mean. 

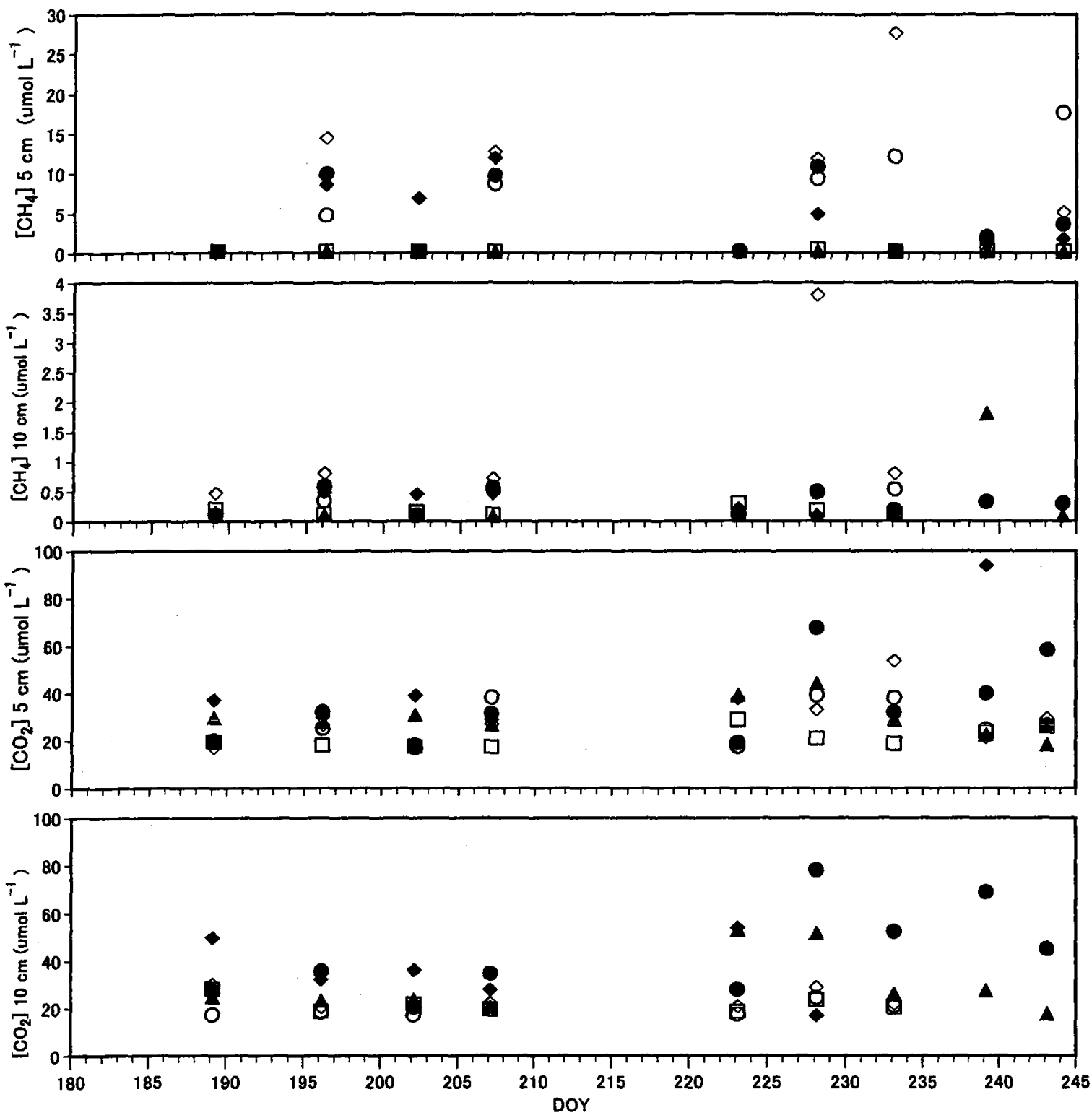

$\triangle$ Sedge Tussock $1 \quad \square$ Fen Tussock 1

- Sedge Tussock $2 \quad 0$ Fen Tussock 2

- Sedge Tussock $3 \quad \diamond \quad$ Fen Tussock 3

Figure 3.10: $\mathrm{CH}_{4}$ and $\mathrm{CO}_{2}$ concentration at 5 and $10 \mathrm{~cm}$ depths at each plot for the sedge tussock and fen tussock sites. 
This trend is also seen to some extent with rain event driven increases in $\mathrm{CH}_{4}$ at $10 \mathrm{~cm}$, (note the axis is an order of magnitude smaller) (Figure 3.10). This pattern is not observed for $\mathrm{CO}_{2}$ except on DOY 228, which had a large precipitation event the day before $\left(15 \mathrm{~mm}\right.$ ) (Figure $3.4 \&$ Figure 3.10). $\mathrm{CO}_{2}$ concentrations are higher in August at the sedge tussocks coinciding with an increase in precipitation events and VWC within the tussocks (Figure 3.4, Figure 3.5 \& Figure 3.10). However, this increasing trend in $\mathrm{CO}_{2}$ was not as strong at the fen tussocks possibly as this site had less water limitations to microbial activity than at the taller/larger sedge tussocks. However, VWC did not suggest this was the case in the one tussock outfitted with sensors at the fen and sedge sites.

\section{Sedge \& Fen Hollows}

At the sedge and fen hollows there was high spatial variability in $\mathrm{CO}_{2}$ and $\mathrm{CH}_{4}$ concentrations both with depth and among profiles, with substantial differences in the shape of the concentration profiles (Figure 3.11). Profile concentrations also varied through time throughout the field season (Figure 3.12). There were similarities in some concentrations profiles of $\mathrm{CH}_{4}$ at the sedge and fen hollows sites with an occasional tendency to increase with depth. However, there were considerable variations to the profile shape in these saturated environments (Figure 3.12). In July when the water table was between 5 and $10 \mathrm{~cm}$ below the moss surface, $0-10 \mathrm{~cm} \mathrm{CH}_{4}$ concentrations were generally low $\left(<15 \mu \mathrm{mol} \mathrm{L}^{-1}\right)$ (Figure $3.4 \&$ Figure 3.12). $\mathrm{CH}_{4}$ concentrations were typically greatest at lower depths from either the $10-20$ or $20-30 \mathrm{~cm}$ intervals. In August as the water table rose above the moss surface, $\mathrm{CH}_{4}$ concentrations at the $0-10 \mathrm{~cm}$ depth 


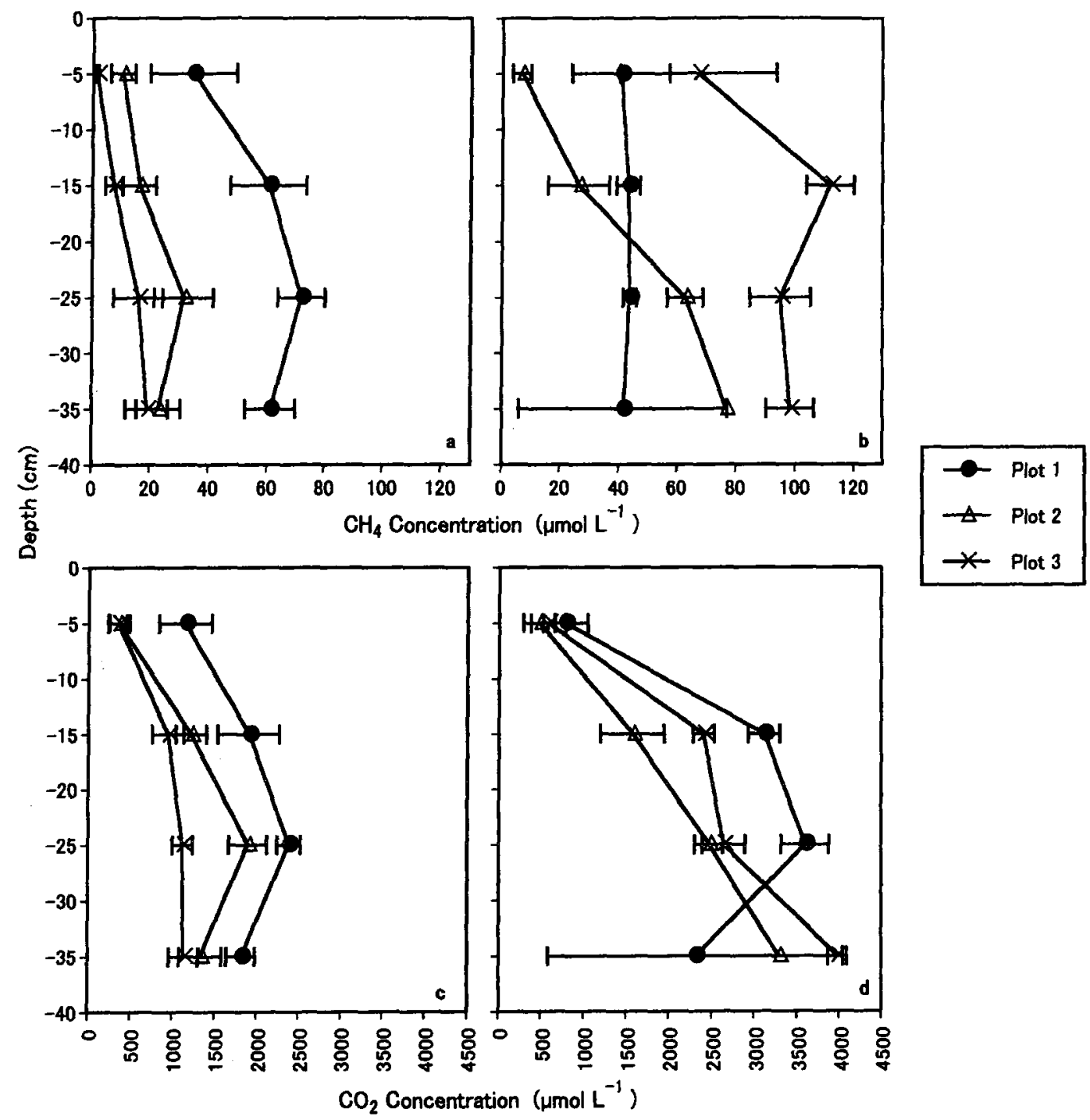

Figure 3.11: Average seasonal subsurface $\mathrm{CH}_{4}$ concentration profiles for the a) sedge hollow and $\mathrm{b}$ ) fen hollow site and $\mathrm{CO}_{2}$ concentration profiles for the c) sedge hollow and d) fen hollow site. Values are means \pm 1 standard error of the mean. The 0-10, 10-20, 20$30,30-40 \mathrm{~cm}$ sampling intervals are represented by mid points of $-5,-15,-25$ and $-35 \mathrm{~cm}$ respectively on the y axis (depth). 

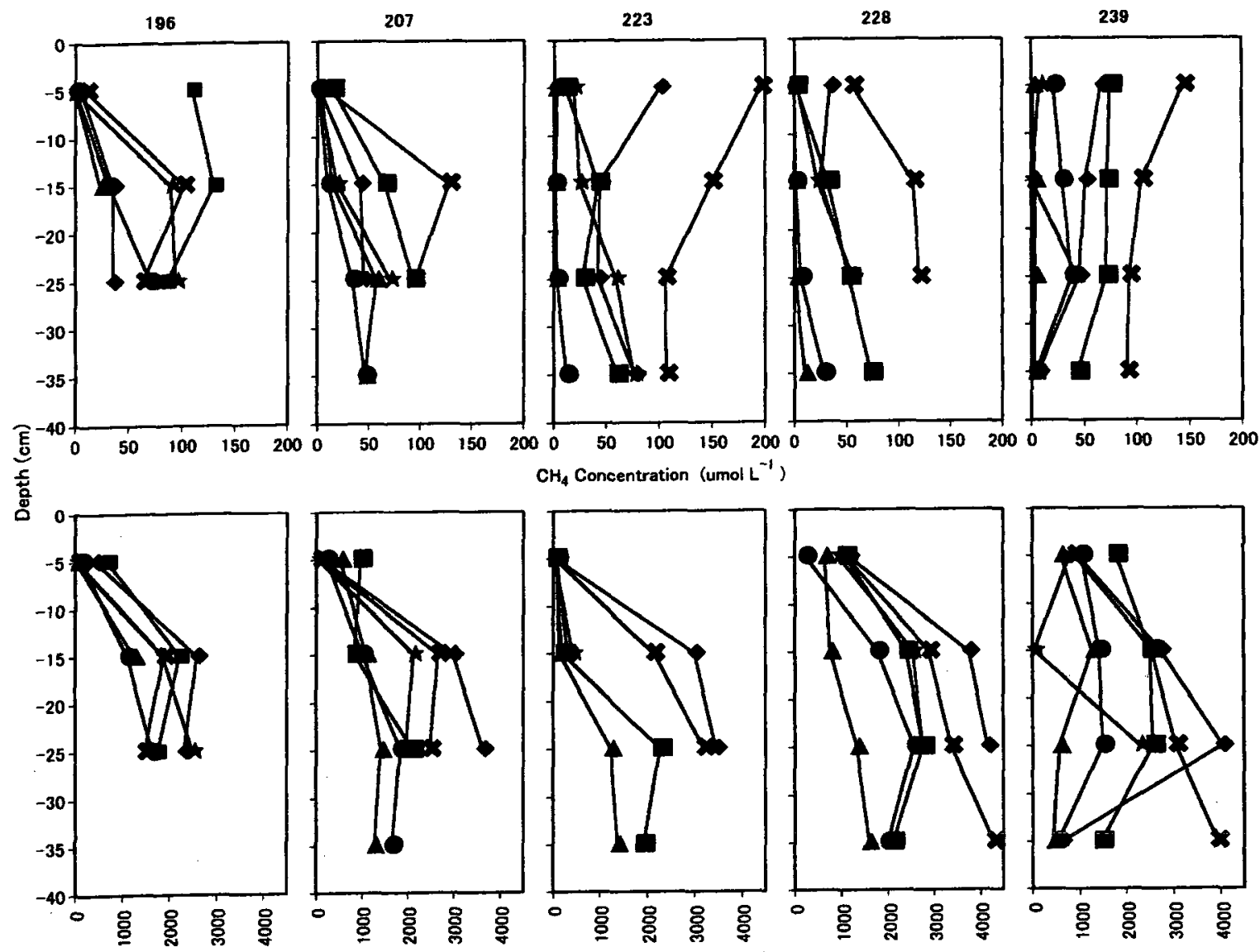

$\mathrm{CO}_{2}$ Concentration (umol $\mathrm{L}^{-1}$ )

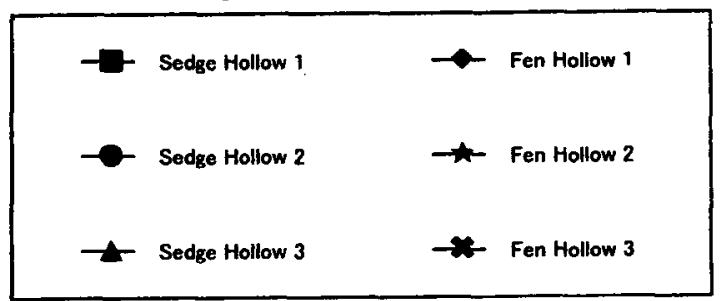

Figure 3.12: $\mathrm{CH}_{4}$ and $\mathrm{CO}_{2}$ concentration profiles at the sedge hollow and fen hollow sites on July $14^{\text {th }}(196)$, July $25^{\text {th }}(207)$, August $10^{\text {th }}(223)$, August $15^{\text {th }}(228)$, and August $26^{\text {th }}$ (239) 2008. The 0-10, 10-20, 20-30, 30-40 cm sampling intervals are represented by mid points of $-5,-15,-25$ and $-35 \mathrm{~cm}$ respectively on the $y$ axis (depth). 
rose. $\mathrm{CH}_{4}$ profile concentrations became more uniform with depth by the end of the season.

$\mathrm{CO}_{2}$ concentrations generally increased with depth at the sedge and fen hollow sites with concentrations reaching local maximums at either the $10-20$ or $20-30 \mathrm{~cm}$ intervals (Figure 3.12). $\mathrm{CO}_{2}$ concentrations at the $0-10 \mathrm{~cm}$ interval also rose in August with an increase in the water table. As peat layers thawed and samplers were pushed further into the peat, we found that concentrations of $\mathrm{CH}_{4}$ and $\mathrm{CO}_{2}$ at depth were on occasion greater than shallower depths (eg. sedge hollow 3 and fen hollow 3 on DOY 228 for $\mathrm{CO}_{2}$ concentration and sedge hollow 1 on DOY 223 for $\mathrm{CH}_{4}$ concentration) and on occasion lower than shallower depths (eg. sedge hollow 1, 2 and 3 and fen hollow 1 on DOY 239 for $\mathrm{CO}_{2}$ concentration and sedge hollow 1 and 2 and fen hollow 1 for $\mathrm{CH}_{4}$ concentration) (Figure 3.12).

\subsubsection{The Influence of Environmental Conditions on $\mathrm{CO}_{2}$ and $\mathrm{CH}_{4}$ Concentrations}

Correlation analysis was used to determine significant relationships between environmental variables and subsurface $\mathrm{CO}_{2}$ and $\mathrm{CH}_{4}$ concentrations (Tables $3.2-3.6$ ). Tables include only those environmental variables that had at least one significant $(\mathrm{p}<$ $0.05)$ Spearman rho value. At the dry heath and shrub sites, temperature was found to be a major control on the production of $\mathrm{CO}_{2}$. Positive correlations were observed between shallow $\mathrm{CO}_{2}$ concentrations and subsurface temperatures (Table 3.2) and $\mathrm{CO}_{2}$ concentrations decreased at all depths through August, coinciding with decreasing 
temperatures (Figure 3.4). Negative correlations between $\mathrm{CO}_{2}$ and temperature at depth may be because $\mathrm{CO}_{2}$ concentrations decreased in August while temperatures are still high at depth due to a lag in temperature propagation into the soil profile. Negative correlations between VWC and $\mathrm{CO}_{2}$ concentrations at 20 and $60 \mathrm{~cm}$ depth at the heath site could be the result of an increase in anaerobic conditions and/or decrease in diffusivity associated with a decrease in air filled pores with increasing water content (Elberling et al., 2004). Negative correlations were also found between $\mathrm{CO}_{2}$ efflux and VWC at the heath site (Chapter 2).

Although a positive correlation between shallow subsurface temperatures and $\mathrm{CH}_{4}$ concentration was found (Table $3.2 \&$ Table 3.3), the lack of a seasonal trend in $\mathrm{CH}_{4}$ concentrations suggests temperature was not the major control on $\mathrm{CH}_{4}$ production or consumption. At the shrub site $\mathrm{CH}_{4}$ concentrations were negatively correlated with $\mathrm{CO}_{2}$ flux, which may be linked to the contrasting control of $\mathrm{VWC}$ on $\mathrm{CO}_{2}$ and $\mathrm{CH}_{4}$ production. Negative correlations between $\mathrm{VWC}$ and $\mathrm{CH}_{4}$ concentration at $40 \mathrm{~cm}$ at the heath site could indicate that increasing water content decreased diffusion of $\mathrm{CH}_{4}$ into the subsurface. Both positive and negative correlations between $\mathrm{CH}_{4}$ flux and $\mathrm{CO}_{2}$ and $\mathrm{CH}_{4}$ concentrations were found at the heath and shrub sites (Table $3.2 \&$ Table 3.3). The positive correlations between $\mathrm{CH}_{4}$ flux and shallow subsurface $\mathrm{CO}_{2}$ and $\mathrm{CH}_{4}$ concentrations indicate there was less uptake of $\mathrm{CH}_{4}$ as concentrations at these depths increased. The negative correlation between $\mathrm{CH}_{4}$ flux and deeper $\mathrm{CH}_{4}$ concentrations, indicate that $\mathrm{CH}_{4}$ uptake was greater when $\mathrm{CO}_{2}$ and $\mathrm{CH}_{4}$ concentrations in deeper layers increased. 


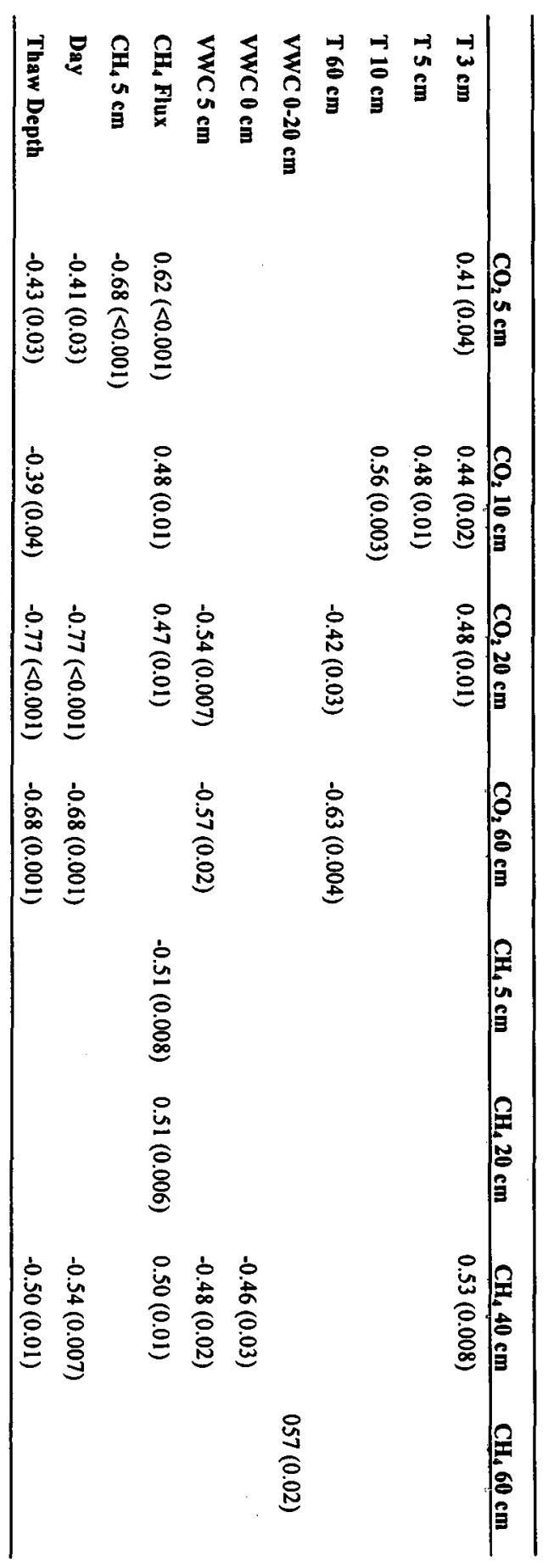

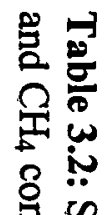

뭉

蛋

을

$\stackrel{2}{\rightleftarrows}$

它

흉.

द.

䒿

꼬으.

密

员

क्ष

整.

马

家

过

중

용

흠

客.

ণ্ণ

$\stackrel{8}{3}$

웅

용

E



苛.

ํㅗㄹ

口

8 


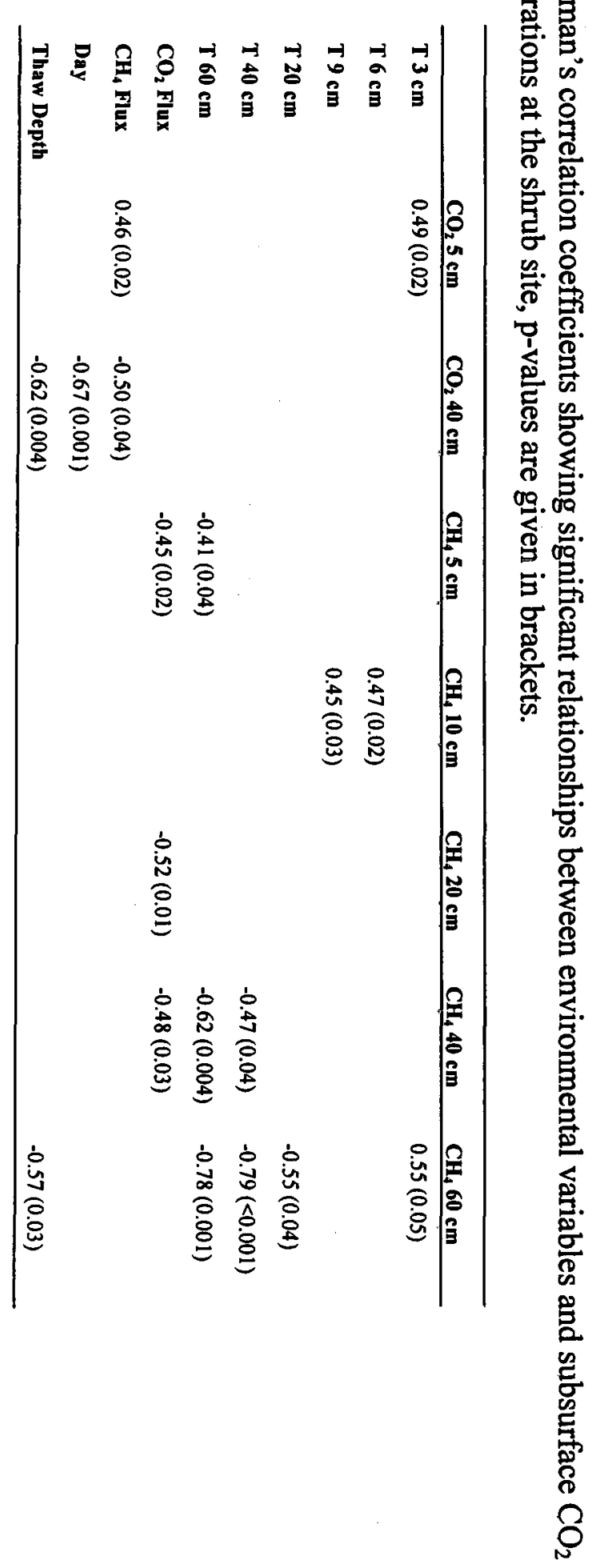


At the sedge and fen tussocks significant correlation between $\mathrm{CO}_{2}$ concentrations and temperature and $\mathrm{VWC}$ on both $\mathrm{CO}_{2}$ and $\mathrm{CH}_{4}$ suggest that both temperature and $\mathrm{VWC}$ had a major control on $\mathrm{CO}_{2}$ production, while $\mathrm{VWC}$ was the major control on $\mathrm{CH}_{4}$ production, which is further supported by trends discussed previously (Table 3.4). Increasing temperatures enhance aerobic respiration of $\mathrm{CO}_{2}$ in the aerated peat in tussocks. The positive correlation with $\mathrm{VWC}$ and $\mathrm{CO}_{2}$ concentration at the fen tussock may indicate aerobic respiration of $\mathrm{CO}_{2}$ was water limited, while a positive correlation between VWC and $\mathrm{CH}_{4}$ concentration at the fen tussock is probably due to increasing anaerobic conditions.

At both the sedge and fen hollows, negative correlations were found between shallow subsurface concentrations of both $\mathrm{CO}_{2}$ and $\mathrm{CH}_{4}$ and subsurface temperatures which could indicate warmer and drier conditions correspond to conditions which favour transport for both gas species which limit build up. This also indicates that warmer drier conditions would limit the presence of anaerobic conditions for $\mathrm{CH}_{4}$ production and increase the occurrence of $\mathrm{CH}_{4}$ oxidation. Positive correlations were found between deeper subsurface concentrations and deeper subsurface temperatures suggesting temperature had a positive effect on production in these saturated zones (Table $3.5 \&$ Table 3.6). Positive correlations between $\mathrm{CO}_{2}$ and $\mathrm{VWC}$ were found at the sedge hollows, while both positive and negative correlations were found between $\mathrm{CH}_{4}$ and VWC for the sedge and fen hollows. Increasing VWC due to a rise in the water table caused shallow subsurface areas to become water saturated, decreasing diffusion of $\mathrm{CO}_{2}$ and $\mathrm{CH}_{4}$ and increasing production of $\mathrm{CH}_{4}$, resulting in larger subsurface concentrations. 
This would explain the positive correlation between VWC and near surface $\mathrm{CO}_{2}$ and $\mathrm{CH}_{4}$. Negative correlations between $\mathrm{VWC}$ and deeper $\mathrm{CH}_{4}$ concentrations may be an artefact of correlation analysis as decreasing temperatures coincided with increasing VWC in August, and positive correlation between temperature and deeper $\mathrm{CH}_{4}$ concentrations were found, as discussed earlier. $\mathrm{CO}_{2}$ flux was negatively correlated to $\mathrm{CH}_{4}$ concentrations at both sites highlighting the contrasting aeration conditions that lead to either aerobic or anaerobic respiration. $\mathrm{CO}_{2}$ flux was negatively correlated to deep $\mathrm{CO}_{2}$ concentrations at the sedge site. This may be due to deeper peat layers thawing by late August and either releasing or producing $\mathrm{CO}_{2}$ while decreasing air temperatures an increasing $\mathrm{VWC}$ decrease the aerobic respiration of $\mathrm{CO}_{2}$. A positive correlation was found between $\mathrm{CH}_{4}$ flux and $\mathrm{CO}_{2}$ concentration at $30-40 \mathrm{~cm}$ at the sedge hollow site which could indicate that $\mathrm{CH}_{4}$ and $\mathrm{CO}_{2}$ concentration at this depth had similar controls such as VWC or temperature.

There were many significant correlations between $\mathrm{CO}_{2}$ and $\mathrm{CH}_{4}$ concentrations and day and thaw depth at most sites. However, this may be an artefact as thaw depth was also positively correlated with VWC at this site (Chapter 2). Substantial rain events in August make it difficult to ascertain how variables such as temperature and thaw depth influence emissions. 
Table 3.4: Spearman's correlation coefficients showing significant relationships between environmental variables and subsurface $\mathrm{CO}_{2}$ and $\mathrm{CH}_{4}$ concentrations at the sedge and fen tussock sites $p$-values are given in brackets.

\begin{tabular}{lccccc}
\hline & \multicolumn{2}{c}{ Sedge Tussock } & \multicolumn{3}{c}{ Fen Tussock } \\
& $\mathrm{CO}_{2} 5 \mathrm{~cm}$ & $\mathrm{CO}_{2} 10 \mathrm{~cm}$ & $\mathrm{CO}_{2} 5 \mathrm{~cm}$ & $\mathrm{CH}_{4} 5 \mathrm{~cm}$ & $\mathrm{CH}_{4} 10 \mathrm{~cm}$ \\
\hline Thaw Depth & & & $0.51(0.007)$ & $0.41(0.03)$ & \\
Day & & & $0.52(0.006)$ & $0.42(0.03$ & \\
T $10 \mathrm{~cm}$ & $0.50(0.008)$ & $0.45(0.03)$ & & & \\
VWC 20 cm & & & $0.46(0.02)$ & & $0.49(0.02)$ \\
\hline
\end{tabular}




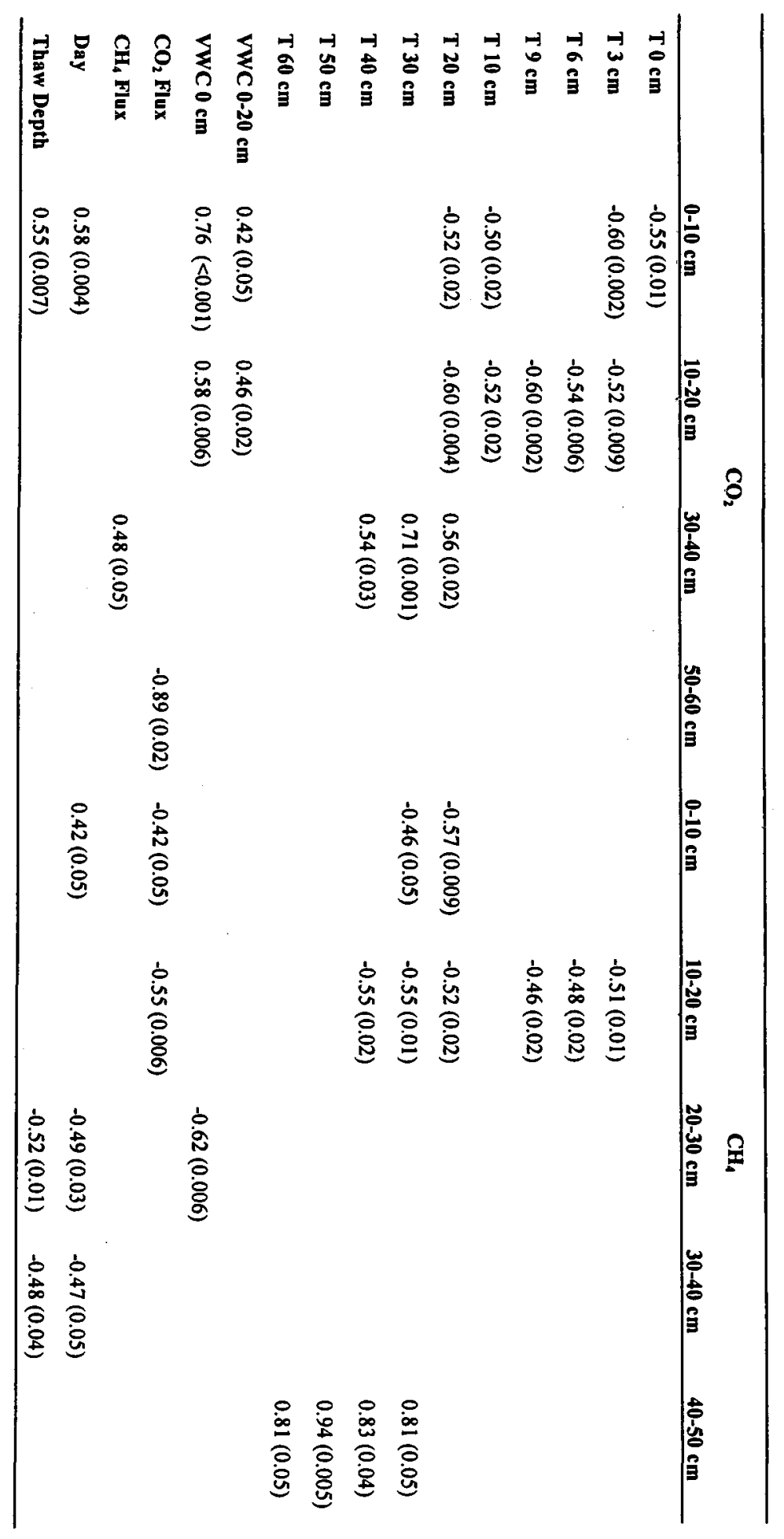

ب

苍

贵

응. 응

8 क

용

훙

跑

옹

宫

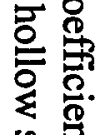

농.

ब

뭉

这

帘

os

穿

응.

§

도

氙

옷

菑 总.

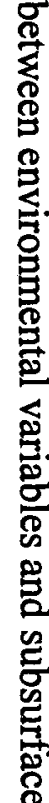

8 
Table 3.6: Spearman's correlation coefficients showing significant relationships between environmental variables and subsurface $\mathrm{CO}_{2}$ and $\mathrm{CH}_{4}$ concentrations at the fen hollow site, $p$-values are given in brackets.

\begin{tabular}{|c|c|c|c|c|c|}
\hline & $\mathrm{CO}_{2} \mathrm{O}-10 \mathrm{~cm}$ & $\mathrm{CO}_{2} 10-20 \mathrm{~cm}$ & $\mathrm{CO}_{2} 30-40 \mathrm{~cm}$ & $\mathrm{CH}_{4}$ 0-10 cm & $\mathrm{CH}_{4} 30-40 \mathrm{~cm}$ \\
\hline$T 0 \mathrm{~cm}$ & $-0.77 \quad(<0.001)$ & & & $-0.74(<0.001)$ & \\
\hline T $3 \mathrm{~cm}$ & & & $0.83(0.04)$ & $-0.54(0.01)$ & \\
\hline T $6 \mathrm{~cm}$ & $-0.52(0.01)$ & & & $-0.64(0.001)$ & $0.79(0.04)$ \\
\hline T $9 \mathrm{~cm}$ & $-0.53(0.01)$ & & & $-0.63(0.002)$ & \\
\hline T $10 \mathrm{~cm}$ & $-0.74 \quad(<0.001)$ & & & $-0.74 \quad(<0.001)$ & $0.83(0.01)$ \\
\hline$T 20 \mathrm{~cm}$ & $-0.64(0.002)$ & & & $-0.73(<0.001)$ & $0.79(0.02)$ \\
\hline T $40 \mathrm{~cm}$ & & & $-0.85(0.007)$ & & \\
\hline$V w C 0-20 \mathrm{~cm}$ & & & & $0.53(0.007)$ & $-0.76(0.03)$ \\
\hline VwC $0 \mathrm{~cm}$ & & & & $0.56(0.009)$ & \\
\hline $\mathrm{CO}_{2}$ Flux & & & & $-0.60(0.002)$ & \\
\hline Day & $0.68(<0.001)$ & & & & $-0.74(0.04)$ \\
\hline Thaw Depth & $0.71 \quad(<0.001)$ & & & $0.74(<0.001)$ & \\
\hline
\end{tabular}




\subsubsection{Ebullition Events}

Although not measured directly, we measured spikes in $\mathrm{CH}_{4}$ concentrations during chamber sampling with magnitudes 100 times larger than diffusive fluxes which suggested ebullition occurred throughout the season at wet sites (Figure 3.13). There were no apparent relationships to subsurface $\mathrm{CH}_{4}$ concentrations or environmental variables. These ebullition events may have occurred due to the physical disturbance of sampling activities. Nonetheless, ebullition events in diffusive chambers may indicate large stocks of subsurface gas bubbles at both the sedge and fen tussock and hollow sites. 


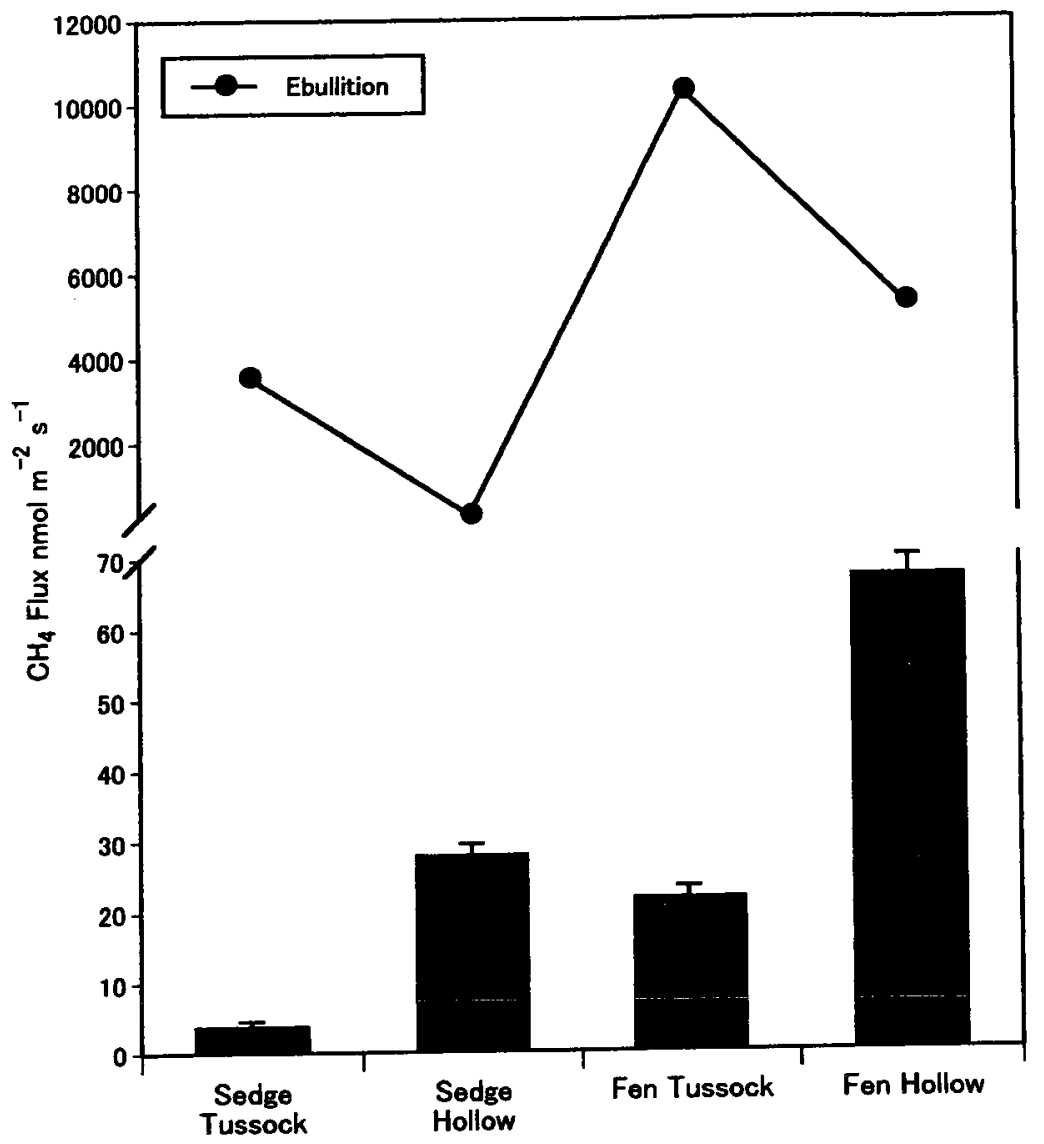

Figure 3.13: Seasonal average $\mathrm{CH}_{4}$ flux and ebullition events as seen in diffusive chambers $\left(\mathrm{nmol} \mathrm{m}^{-2} \mathrm{~s}^{-1}\right)$. 


\subsection{Discussion}

The results from this study highlight the great amount of spatial and temporal variability in subsurface $\mathrm{CO}_{2}$ and $\mathrm{CH}_{4}$ concentrations that occur in these shallow arctic soils despite a relatively short growing season, cool temperatures, and the presence of permafrost. The results highlight how variations in the soil thermal and moisture regimes affect production, transformation and transport of these trace gases in different ways within the different vegetation communities, resulting in dramatically different subsurface $\mathrm{CO}_{2}$ and $\mathrm{CH}_{4}$ concentrations in these mineral and peat soils.

\subsubsection{Heath \& Shrub Sites}

Average concentrations of subsurface $\mathrm{CO}_{2}$ ranged from $\sim 39$ and $24 \mu \mathrm{mol} \mathrm{\textrm {L } ^ { - 1 }}$ ( $\sim 942$ and 581 ppmv) to $\sim 174$ and $297 \mu \mathrm{mol} \mathrm{L}^{-1}(\sim 4194$ and $8416 \mathrm{ppmv})$ in the mineral soils of the heath and shrub sites respectively. These maximum values were lower than those found in the soil of a highly productive coastal Douglas-fir forest where $\mathrm{CO}_{2}$ reached up to $10000 \mathrm{ppmv}$ (Jassal et al., 2004) but were in the range of those from tundra heath soils (Elberling, 2003) and pasture and forest soils in Nova Scotia, Canada (Risk et al., 2002). Average concentrations of $\mathrm{CH}_{4}$ at both heath and shrub sites typically ranged from $\sim 0.004-0.09 \mu \mathrm{mol} \mathrm{L}_{\mathrm{g}}^{-1}(\sim 0.1-2.2 \mathrm{ppmv})$ which was similar in magnitude to those in upland Alaskan forest soils (Billings et al., 2000) and forest soils in New Hampshire (Crill, 1991) and North Carolina (McLain et al., 2002), with occasional high concentrations up to $\sim 2 \mu \mathrm{mol} \mathrm{L} \mathrm{L}^{-1}(\sim 50 \mathrm{ppmv})$. Although these sites experience colder conditions and shorter growing seasons subsurface $\mathrm{CO}_{2}$ and $\mathrm{CH}_{4}$ concentrations during 
the growing season were comparable to those found in forest soils in more temperate latitudes.

In the coarse textured soils of the heath and shrub site, increasing subsurface $\mathrm{CO}_{2}$ concentrations with depth likely indicate storage of $\mathrm{CO}_{2}$ due to decreased diffusivity, from decreased porosity, rather than high rates of production (Risk et al., 2002; Jassal et al., 2004). As $\mathrm{CO}_{2}$ production is strongly temperature dependent, production rates are larger in July and early August when temperatures are higher resulting in large $\mathrm{CO}_{2}$ concentrations and $\mathrm{CO}_{2}$ efflux (Chapter 2, Figure 2.9). When temperatures decrease, production slows and $\mathrm{CO}_{2}$ concentrations and efflux decrease (Crill, 1991). Negative correlations between temperature and $\mathrm{CO}_{2}$ concentration at depth and positive correlations in the upper layers suggests that the majority of $\mathrm{CO}_{2}$ is produced in the upper layers. Temperatures increase at depth through August, yet $\mathrm{CO}_{2}$ concentrations and $\mathrm{CO}_{2}$ efflux decreases in late August as air and near surface temperatures decrease. This is in agreement with a study by Elberling (2003) at a tundra heath site in Greenland which found that more than $80 \%$ of the temporal variations of soil respiration could be explained by near-surface soil temperature and that the majority of $\mathrm{CO}_{2}$ production occurs in the shallow subsurface layers. Greater rates of $\mathrm{CO}_{2}$ production in near surface layers are presumably due to greater substrate availability and aeration in the surface layers of these mineral soils (Elberling et al., 2004).

Decreasing subsurface $\mathrm{CH}_{4}$ concentrations with depth indicate that methanotrophic activity depleted $\mathrm{CH}_{4}$ in the upper soil layers creating a gradient to draw 
$\mathrm{CH}_{4}$ from the atmosphere into the soil (McClain et al., 2002). The inverse relationship between $\mathrm{CO}_{2}$ and $\mathrm{CH}_{4}$ subsurface concentration profiles is common in aerated soils due to the different balance between biological and diffusion process for the two gases (Crill, 1991). $\mathrm{CO}_{2}$ is produced within the profile by auto- and heterotrophic respiration while methanotrophic activity is limited by the diffusive transport of $\mathrm{CH}_{4}$ into the soil (Flessa, 2008). However, early in the season, both the heath and shrub sites had relatively high $\mathrm{CH}_{4}$ concentrations at $60 \mathrm{~cm}$ when the VWC was observed to be higher at the shrub site likely due to melt and impeded drainage by the impermeable frozen soil layer at the bottom of the active layer. The heath site had low average $\mathrm{CH}_{4}$ uptake during this time, while there was no clear relationship with $\mathrm{CH}_{4}$ flux at the shrub site. Positive correlation between VWC and $\mathrm{CH}_{4}$ at the heath site indicates increasing moisture conditions decreased $\mathrm{CH}_{4}$ uptake rates, possibly due to limits on methane oxidation from increasing anaerobic conditions and/or increasing VWC limiting diffusion into the soil (Crill, 1991). Negative correlation between $\mathrm{VWC}$ and $\mathrm{CH}_{4}$ concentration at $40 \mathrm{~cm}$ at the heath site could indicate that increasing water content decreased diffusion of $\mathrm{CH}_{4}$ to deeper soil depths. A negative relationship between VWC and methane consumption has been found in other aerated soils, due to diffusion limitations on $\mathrm{CH}_{4}$ supply (Billings et al., 2000; McClain et al., 2002). Therefore we hypothesize that higher VWC decreased $\mathrm{CH}_{4}$ consumption and possibly increased $\mathrm{CH}_{4}$ production in micro-sites. In addition, high concentrations of $\mathrm{CH}_{4}$ were observed in the surface layers on occasion at both sites although shrub $\mathrm{CH}_{4}$ concentrations were clearly greater. The shrub site had a deeper organic layer and greater organic matter content in the shallow subsurface. This organic 
matter may have been a relatively labile carbon substrate, which may be why surface $\mathrm{CH}_{4}$ concentrations were higher. When comparing the $\mathrm{CH}_{4}$ flux measurements for these two sites, lower uptake rates and periodic release of $\mathrm{CH}_{4}$ were found at the shrub site in comparison to the heath site which always had relatively high $\mathrm{CH}_{4}$ uptake rates (Chapter 2, Table 2.7). Christensen et al. (1997) also suggest that subarctic heath systems may constitute a significant sink for atmospheric $\mathrm{CH}_{4}$. The occurrence of temporary $\mathrm{CH}_{4}$ concentration peaks and periodic $\mathrm{CH}_{4}$ efflux, due to either the creation of anaerobic conditions from water pooling at the base of the active layer or at the surface after large precipitation events, indicate that localized increases in VWC were an important control on $\mathrm{CH}_{4}$ production in these dry coarse textured soils. Aside from these soil moisture influences, subsurface $\mathrm{CH}_{4}$ concentrations showed little temporal variability as was also shown in surface flux measurements (Chapter 2, Figure 2.10). The lack of a seasonal trend in subsurface $\mathrm{CH}_{4}$ concentrations suggests that production, diffusion and oxidation of $\mathrm{CH}_{4}$ is much more sensitive to VWC than temperature in these mineral soils (Crill, 1991; Flessa et al., 2008).

\subsubsection{Sedge \& Fen Tussock Sites}

The sedge and fen tussocks were zones of aeration above the water table for most of the field season with high spatiotemporal variability in concentrations of $\mathrm{CO}_{2}$ and particularly $\mathrm{CH}_{4} . \mathrm{CO}_{2}$ production was largely controlled by temperature and $\mathrm{VWC}$, while $\mathrm{CH}_{4}$ production was controlled by VWC. Subsurface $\mathrm{CO}_{2}$ concentrations ranged from $\sim 17-93 \mu \mathrm{mol} \mathrm{L}_{\mathrm{g}}^{-1}$ while $\mathrm{CH}_{4}$ concentrations ranged from $0.07-28 \mu \mathrm{mol} \mathrm{L} \mathrm{L}^{-1}$. 
Few studies have found $\mathrm{CH}_{4}$ production in the unsaturated zone as the high presence of oxygen in aerated peat is thought to restrict anaerobic microbial activity (Sundh et al., 1994). High $\mathrm{CH}_{4}$ concentrations in aerated tussocks at $5 \mathrm{~cm}$ depth are presumably due to the creation of localized zones of production. The occurrence of these production zones are linked to changing antecedent conditions namely, large precipitation events and atmospheric turbulence. Thus, the presence of high concentrations is due to both the creation of conditions favourable for production and for inhibited transport due to low atmospheric turbulence. The production of $\mathrm{CH}_{4}$ in wetland soil in the presence of oxygen has been seen in other studies (Wagner et al., 2003; Coles \& Yavitt, 2004; Knorr et al., 2008). Research by Knorr et al. (in press) found that precipitation events have also been shown to substantially increase $\mathrm{CH}_{4}$ concentrations in the uppermost peat layer of a fen in north-eastern Bavaria. In this study, $\mathrm{CO}_{2}$ and $\mathrm{CH}_{4}$ concentration peaks were similar in magnitude to those found in this study. Researchers suggested that a transient zone of methanogenesis was created after large precipitation events. The production of $\mathrm{CH}_{4}$ in unsaturated peat indicates that near surface peat responds quickly with wetting, due to the high tolerance of methanogenic microbes to fluctuating redox conditions and the availability of degradable substrates from plant roots (Knorr et al., 2008; Knorr et al., in press).

Not all concentrations at $5 \mathrm{~cm}$ were high after precipitation events. High $\mathrm{u} *$ values on days after precipitation events (ex: DOY 239) lead to flushing of potentially high concentrations of $\mathrm{CH}_{4}$ out of the aerated tussocks (Figures $3.4 \& 3.8$ ). Dramatic peaks of $\mathrm{CH}_{4}$ concentration in aerated peat found by Knorr et al. (in press) was also not sustained, 
however it is uncertain as to the mechanisms controlling the presence of these high concentrations. Atmospheric turbulence has been found to increase $\mathrm{CH}_{4}$ emission rates (measured with eddy covariance towers) in other peatlands (Hargreaves et al., 2001; Sachs et al., 2008; Wille et al., 2008).

Subsurface $\mathrm{CO}_{2}$ and $\mathrm{CH}_{4}$ concentrations in the sedge and fen tussocks increased in mid to late August while $\mathrm{CO}_{2}$ efflux measurements decreased and $\mathrm{CH}_{4}$ flux increased (Chapter 2, Figure 2.9 \& Figure 2.10). This suggests that increasing $\mathrm{CO}_{2}$ concentrations were not a function of greater $\mathrm{CO}_{2}$ production but of limited diffusion to the atmosphere as VWC increased and temperatures cooled. In contrast, increasing $\mathrm{CH}_{4}$ concentration and efflux (Chapter 2, Figure 2.10) in August when VWC increased and positive correlations between VWC and subsurface $\mathrm{CH}_{4}$ concentrations suggest that increasing anaerobic conditions and decreasing zones of oxidation in surface peat led to greater release of $\mathrm{CH}_{4}$ from these peatland sites despite the cooler temperatures.

Subsurface concentrations below the tussocks into the saturated peat could potentially be estimated using the $\mathrm{CO}_{2}$ and $\mathrm{CH}_{4}$ concentration profiles from the corresponding hollow sites at the fen and sedge sites. However the presence of tussocks likely had a significant influence on $\mathrm{CO}_{2}$ and $\mathrm{CH}_{4}$ transport to the atmosphere with much $\mathrm{CH}_{4}$ being oxidized as it left the saturation zone (Whalen \& Reeburg, 1990). Tussocks may have also led to cooler subsurface temperatures in comparison to areas with no tussocks, as aerated peat has a lower thermal conductivity then saturated zones. The influence of vegetation on the supply of substrates throughout the profile may have also varied due to the presence of a larger aerated zone. 


\subsubsection{Sedge \& Fen Hollow Sites}

As with the tussock sites, high spatiotemporal variability in subsurface profile $\mathrm{CO}_{2}$ and $\mathrm{CH}_{4}$ concentrations at the sedge and fen hollows were observed as a result of variations in aeration, affecting rates of production, transport and oxidation of $\mathrm{CH}_{4}$ and also potentially due to differences in peat and pore water chemistry (Strack \& Waddington, 2008; Dinsmore et al., 2009). Vascular vegetation may also affect spatial variability of subsurface concentrations as plant roots provide exudates and transport both $\mathrm{CH}_{4}$ to the atmosphere and oxygen to below the water table (Popp et al., 1999; Joabsson \& Christensen, 2001; Dinsmore et al., 2009).

While negative correlations between shallow subsurface $\mathrm{CO}_{2}$ and $\mathrm{CH}_{4}$ concentrations and temperature suggest that warmer drier conditions in the shallow subsurface favoured diffusion and limited $\mathrm{CH}_{4}$ production, positive correlations between deep subsurface $\mathrm{CO}_{2}$ and $\mathrm{CH}_{4}$ concentrations and soil temperatures suggests temperature had a positive effect on production in deeper saturated zones. Other studies have found that $\mathrm{CH}_{4}$ emission only positively correlates with soil temperature in saturated zones as aeration gains more importance in controlling $\mathrm{CH}_{4}$ emission in non saturated zones (Christensen, 1993; Torn \& Chapin, 1993; Nykänen et al., 1998; Sachs et al., 2008).

The highest $\mathrm{CH}_{4}$ concentrations were frequently observed in July at the 10-20 and $20-30 \mathrm{~cm}$ intervals at many sites when the water table was $\sim 5-10 \mathrm{~cm}$ below the surface. Other studies have found peak concentrations of $\mathrm{CH}_{4}$ just below the water table and suggested that the combination of anaerobic conditions, decreased diffusivity and high 
near surface substrate availability lead to high rates of production in this zone (Sundh $e t$ al., 1994; Joabsson \& Christensen, 2001; Heyer et al., 2002; Wagner et al., 2003).

Increasing near surface $\mathrm{CO}_{2}$ and $\mathrm{CH}_{4}$ concentrations in August occurred when the water table was at or above the moss surface, decreasing diffusivity as pores became saturated (transport by gas-phase diffusion is $10^{5}$ times faster than diffusion in water) and increasing anaerobic conditions for $\mathrm{CH}_{4}$ production and decreasing zones of $\mathrm{CH}_{4}$ oxidation (Whalen \& Reeburgh, 1990). This trend is supported by the positive correlations between VWC and near surface $\mathrm{CO}_{2}$ and $\mathrm{CH}_{4}$ and the decreasing $\mathrm{CO}_{2}$ emissions and increasing $\mathrm{CH}_{4}$ emissions at both sites during the same time period (Chapter 2, Figure 2.9 \& Figure 2.10).

As the active layer deepened, recently thawed layers occasionally showed high concentrations of $\mathrm{CO}_{2}$ and $\mathrm{CH}_{4}$ (Figure 3.12), indicating either $\mathrm{CO}_{2}$ and $\mathrm{CH}_{4}$ released from the frozen peat or immediate production at depth. Wagner et al., (2003) measured substantial $\mathrm{CH}_{4}$ production at the lower boundary of the active layer at temperatures around $1{ }^{\circ} \mathrm{C}$ and suggested that microorganisms in permafrost soils are well adapted to the extreme temperature regime. Episodic $\mathrm{CH}_{4}$ release from thawing soils as well as correlations between thaw depth and $\mathrm{CH}_{4}$ emission has been shown in other studies (Joabsson \& Christensen, 2001; Heyer et al., 2002; Wagner et al., 2003; Sachs et al., 2008).

Concentrations of $\mathrm{CH}_{4}$ ranging from $\sim 0.004-149 \mu \mathrm{mol} \mathrm{L}^{-1}$ are similar to those found in a mixed forested peatland (Coles \& Yavitt, 2004), a fen in north-eastern Bavaria (Knorr et al., in press) and in the lower range of those found at a Québec fen (Strack \& 
Waddington, 2008). $\mathrm{CH}_{4}$ concentrations were quite low compared to those of most other sites, for example in comparison to those of vegetation communities in a Sweedish mire (Sundh et al., 1995), a raised bog (Frensel \& Karofeld, 2000), polygonal tundra in Siberia (Wagner et al., 2003) and substantially lower than concentrations found at a fen in northern Minnesota where concentrations maximums had a magnitude 10 times greater than those found at our sites (Chasar et al., 2000). Concentrations of $\mathrm{CO}_{2}$ and $\mathrm{CH}_{4}$ were much higher than values at a Scotland bog (Dinsmore et al., 2009). $\mathrm{CO}_{2}$ concentrations ranging from $\sim 26-5167 \mu \mathrm{mol} \mathrm{L}^{-1}$ were also similar to those found by Knorr et al. (in press) and on the lower range of those found in peat monoliths of a temperate fen (Knorr et al., 2008).

Although the sedge and fen hollows were mostly anaerobic environments, concentrations of $\mathrm{CO}_{2}$ were higher than $\mathrm{CH}_{4}$, a common result in most northern peat soils where anaerobic microbial activity produces more $\mathrm{CO}_{2}$ than $\mathrm{CH}_{4}$ (Blodau, 2002; Laing, 2008). The greater production of $\mathrm{CO}_{2}$ results in higher efflux of $\mathrm{CO}_{2}$ versus $\mathrm{CH}_{4}$ (although $\mathrm{CO}_{2}$ efflux measurements include plant respiration of $\mathrm{CO}_{2}$, we assume soil respiration of $\mathrm{CO}_{2}$ is still higher than $\mathrm{CH}_{4}$ in these soils) (Chapter 2, Table 2.6 \& Table 2.7). Research suggests that methanogenic conditions in peat soils rely on a constant supply of easily decomposable substrates (Wagner et al., 2003; Yavitt \& SeidmannZager, 2006) indicating that plant carbon allocation to roots is an important control on $\mathrm{CH}_{4}$ production (Joabsson \& Christensen, 2001; Coles \& Yavitt, 2004). Low $\mathrm{CH}_{4}$ concentrations at our wet arctic sites in comparison to warmer temperate peatlands may be due to both the colder temperatures and short growing season, which limits plant 
carbon accumulation and associated supply of substrates. The ability to investigate vegetation associated seasonal controls on $\mathrm{CH}_{4}$ exchange was hampered as field measurement started after leaf out and during senescence substantially large precipitation events increased in occurrence. Therefore the substrate influence on $\mathrm{CH}_{4}$ production at this site is difficult to analyze. However we did see a seasonal control on $\mathrm{CO}_{2}$ efflux (Chapter 2, Figure 2.9) which is presumably related to a decrease in soil and plant respiration due to decreasing temperatures and plant senescence.

Various studies have linked sporadic increases in $\mathrm{CH}_{4}$ concentration to the presence of entrapped gas bubbles (Chasar et al., 2000). The build up and release of these bubbles via triggers such as changes in atmospheric pressure and increasing atmospheric turbulence are believed to provide a substantial contribution to the emission of $\mathrm{CH}_{4}$ to the atmosphere from peatlands (Tokida et al., 2007; Sachs et al., 2008). The presence and location of subsurface gas bubbles at the sedge and fen sites in our study is largely unknown. Sporadic pulses in $\mathrm{CH}_{4}$ concentration were captured throughout the field season in diffusion chambers indicating that ebullition events occur. However, high concentrations of $\mathrm{CH}_{4}$ of about $390 \mu \mathrm{mol} \mathrm{L}{ }^{-1}$ (equivalent to $\mathrm{CH}_{4}$ partial pressures of around $0.2 \mathrm{~atm}$ ) are required to enable bubble formation to occur (Fechner-Levy \& Hemond, 1996; Beer and Blodau, 2007; Knoor et al., in press) and in our study subsurface $\mathrm{CH}_{4}$ concentrations never exceeded $200 \mu \mathrm{mol} \mathrm{L}{ }^{-1}$. Conversly, a study using membrane inlet quadrupole mass spectrometry (QMS) to examine bubbles within bog peat cores found that disolved concentrations responsible for gas bubble formation were on average 80-83 $\mu \mathrm{mol} \mathrm{L}^{-1}$ (Laing et al., 2008). This QMS study was able to distinguish 
between $\mathrm{CH}_{4}$ concentrations from the gas and dissolved phase and found lower dissolved concentrations relative to other QMS studies. Thus, there may be subsurface bubbles at our sites, but further investigation is required.

By the end of the field season (end of August), temperatures had dropped considerably and $\mathrm{CO}_{2}$ and $\mathrm{CH}_{4}$ concentrations reached maximum magnitudes at the sedge and fen hollows due to water logging from large precipitation events. It has been shown that in early winter during the freeze-up period $\mathrm{CH}_{4}$ emissions increase significantly, purportedly due to gradual freezing where $\mathrm{CH}_{4}$ is squeezed out from soils (Mastepanov $e t$ al., 2008). As the large stock of both $\mathrm{CO}_{2}$ and $\mathrm{CH}_{4}$ at our sedge and fen sites may potentially be emitted in large quantities during freeze up, it is important to determine interannual controls on subsurface storage as this may be an important component of the annual carbon balance. 


\subsection{Conclusion}

Examination of subsurface concentrations of $\mathrm{CO}_{2}$ and $\mathrm{CH}_{4}$ at six vegetation communities in the low arctic revealed major differences between subsurface gas dynamics in mineral and peat soils. Sedge and fen tussock and hollow sites displayed much higher heterogeneity among profiles than the heath and shrub sites. Due to the complexity of controlling factors, simple identification of controls on subsurface concentrations was difficult, yet some key trends were found. Temperature was a major control on $\mathrm{CO}_{2}$ production at dry sites, while VWC controlled the production and transport of $\mathrm{CO}_{2}$ and $\mathrm{CH}_{4}$ and oxidation of $\mathrm{CH}_{4}$ at all sites. At sedge and fen tussocks concentrations were controlled by large precipitation events and atmospheric turbulence. High subsurface variability at sedge and fen hollows suggested that the water table and associated aeration status played a large role on the production and transport of $\mathrm{CO}_{2}$ and $\mathrm{CH}_{4}$ and the oxidation of $\mathrm{CH}_{4}$.

We found that controls on subsurface production, oxidation and transport all contributed to the surface-atmosphere flux of $\mathrm{CO}_{2}$ and $\mathrm{CH}_{4}$. Different processes such as diffusion in aerated and saturated soils and atmospheric turbulence can have major controls on gaseous release to the atmosphere. This confirmed that conditions affecting subsurface carbon dynamics can have major impacts on the surface-atmosphere exchange of $\mathrm{CO}_{2}$ and $\mathrm{CH}_{4}$.

Subsurface gas dynamics are proving to be an important component in subsurface carbon cycling in peatlands. Although measuring the occurrence and controls on gas 
bubble formation and release in peat is difficult, our understanding of how subsurface carbon dynamics in peatlands affect $\mathrm{CO}_{2}$ and $\mathrm{CH}_{4}$ efflux will be enhanced by further research in this area (Rosenberry et al., 2006). Ebullition events in diffusive chambers of this study may indicate large stocks of subsurface gas bubbles. Chamber methods eliminate near surface turbulence, alter internal pressure and cannot adequately capture ebullition events in peatlands. Therefore the use of gas traps and micrometerological methods should prove useful in further examining the controls on diffusive flux and ebullition in these wet arctic environments (Kutzbach et al., 2007; Sachs et al., 2008).

These mineral and peat soils will respond differently to climate change. Increasing temperatures and deepening active layers may lead to increasing $\mathrm{CO}_{2}$ production and $\mathrm{CH}_{4}$ oxidization in mineral soils. Deepening of the active layer may also expose frozen carbon to decomposition and increasing soil drainage will raise the aeration status of many vegetation communities, increasing diffusion of $\mathrm{CH}_{4}$ into the soil (Crill, 1991; Flessa et al., 2008). At peatland sites changes in soil moisture and thermal regimes are more complex and difficult to predict. Increasing temperatures and deepening of the active layer may decrease water table depths, increasing aerobic respiration of newly exposed carbon and decreasing $\mathrm{CH}_{4}$ emission with greater aeration (Rodionow et al., 2006). However as the dynamics of the subsurface gaseous phase are not well understood further research in this area will improve estimates of the potential impacts of climate change to carbon cycling in arctic peatlands. 


\section{Summary \& Conclusions}

Arctic ecosystems consist of a heterogeneous mix of vegetation types over short distances. Processes controlling arctic terrestrial carbon dynamics are complex, occurring at various spatial and temporal scales. As a result the exchange of carbon between the tundra and the atmosphere is highly variable across arctic landscapes. This leads to significant uncertainty when trying to predict how the carbon budget of this landscape may respond to short-term variations in weather and long-term climate change.

In order to quantify and gain insight on the important controls on tundra-atmospheric exchange of carbon dioxide $\left(\mathrm{CO}_{2}\right)$ and methane $\left(\mathrm{CH}_{4}\right)$, this study examined fluxes and subsurface concentrations of $\mathrm{CO}_{2}$ and $\mathrm{CH}_{4}$ for six different vegetation community plots at Daring Lake, N.W.T during the 2008 growing season. Vegetation community plots included heath and shrub tundra, sedge tussock and hollows and fen tussock and hollows.

In terms of the research hypothesis outlined at the outset of this study, we can draw a number of conclusions:

1. $\mathrm{CO}_{2}$ and $\mathrm{CH}_{4}$ fluxes and their subsurface concentrations varied considerably within and among vegetation community types and through time. Among vegetation community types, relative variations in $\mathrm{CO}_{2}$ exchanges were more subtle than those for $\mathrm{CH}_{4}$ with all communities showing net $\mathrm{CO}_{2}$ uptake while small rates of $\mathrm{CH}_{4}$ uptake at the heath and shrub sites contrasted dramatically with large emissions at the wetter sedge and fen sites. In contrast, variations through time were relatively greater for $\mathrm{CO}_{2}$ fluxes 
than for $\mathrm{CH}_{4}$ fluxes which alludes to differences in the importance of moisture and temperature for driving these temporal and spatial variations as discussed further below. Overall, subsurface concentration profiles of $\mathrm{CH}_{4}$ mirrored these results with dramatic differences in the direction and magnitude of vertical gradients while in almost all cases, $\mathrm{CO}_{2}$ increased with depth.

All of the fluxes and concentrations observed at Daring Lake in 2008 were typically within the wide range of values found at other arctic locations. Given the variability observed within this single small Southern Arctic valley, this highlights the even greater variability that exists when examining carbon exchanges at regional and circumpolar scales.

Using a simple model to estimate growing season fluxes at these six vegetation communities, all but the heath site were net carbon sinks over the July/August 2008 measurement period with the largest sinks at the wetter sedge hollow and fen tussock sites. By including $\mathrm{CH}_{4}$ measurements in the global warming potential assessment, most of the wet sites produced positive radiative forcing on a 20 year timescale with both the sedge and fen hollows remaining a positive radiation forcing on a 100 year timescale. However, the long-term impact of sustained carbon uptake on the climate system must be considered when discussing the role these peatlands play on the climate system.

2. Spatial variations in $\mathrm{CH}_{4}$ fluxes were clearly related to variations in soil moisture with greater emissions occurring in wetter environments while $\mathrm{CH}_{4}$ uptake occurred on 
occasion at the well drained mineral soil locations. This agrees well with the large body of literature showing that anaerobic conditions lead to $\mathrm{CH}_{4}$ production. Within the wet communities, microtopography had a considerable influence on the moisture conditions of the near-surface peat with tussocks being above the water table and drier than lower areas (hollows) such that $\mathrm{CH}_{4}$ fluxes from tussocks were considerably lower likely as a result of oxidation of $\mathrm{CH}_{4}$ as it diffuses through this aerobic zone. However, on occasion, $\mathrm{CH}_{4}$ concentrations were very high in near surface tussock soils suggesting the potential for sporadic and rapid production of $\mathrm{CH}_{4}$ with local increases in moisture likely taking advantage of high concentrations of labile substrates.

$\mathrm{NEE}$ and $\mathrm{CO}_{2}$ emissions were less clearly related to soil moisture variations although the driest warmest location (shrub site) was associated with greater rates of respiration than the other five vegetation communities. Net uptake of $\mathrm{CO}_{2}$ was slightly greater in the wetter sites, more as a function of greater GEP rather than reduced $\mathrm{CO}_{2}$ efflux although this interpretation depended somewhat on whether direct measurements or the parameterization of a simple NEE model was used. Overall, results suggest that although aerobic production of $\mathrm{CO}_{2}$ may have been inhibited in waterlogged areas, this was offset by greater autotrophic respiration by the relatively fast growing sedge species such that total $\mathrm{CO}_{2}$ efflux was relatively similar among sites. These findings agree well with those from the micrometeorological towers measuring NEE from the upland mixed tundra area and in the fen at Daring Lake, where fen NEE is slightly greater than mixed tundra NEE as a function of variations in GEP (E. Humphreys, pers comm.). Although there was a relatively large range in soil moisture conditions associated with the six different 
vegetation community types, this study did not include the more xeric communities found on eskers or other rapidly drained areas that might have resulted in stronger relationship between $\mathrm{CO}_{2}$ exchange and soil moisture. The heath and shrub communities were both located midslope on relatively level terrain and despite being located on coarse textured well drained soils, lateral inputs of water via drainage from upper slopes confined within a thaw layer of $1 \mathrm{~m}$ or less maintained enough moisture to support relatively productive vegetation.

3. Temperature and soil moisture variations were not equally important in determining temporal variations in $\mathrm{CO}_{2}$ and $\mathrm{CH}_{4}$ fluxes in all vegetation community types. Although the magnitude of temporal variations in $\mathrm{CH}_{4}$ fluxes generally increased with increasing wetness, these variations were positively and significantly correlated with soil volumetric water content at four of the six vegetation communities including both drier (heath) and wetter (fen tussock) sites. Soil temperature variations were only significantly correlated to variations in $\mathrm{CH}_{4}$ fluxes in two of the six sites. In these two sites (sedge tussocks and hollows) however, the effects of temperature on $\mathrm{CH}_{4}$ were inconsistent. Belowground $\mathrm{CH}_{4}$ concentrations were clearly related to the position of the water table variations at the wettest sites (sedge and fen hollows) with maximum $\mathrm{CH}_{4}$ concentrations located near the water table $\sim 10 \mathrm{~cm}$ below the surface earlier in the season while later in the season, near surface $\mathrm{CH}_{4}$ concentrations dramatically increased as the water table rose. In the tussock vegetation communities, very high near-surface concentrations of $\mathrm{CH}_{4}$ occurred immediately after rainfall events regardless of 
temperature variations. These high concentrations could be quickly reduced to near ambient concentrations with turbulent atmospheric conditions indicating that $\mathrm{CH}_{4}$ transport is not solely a diffusive process.

In contrast to the relatively consistent effects of moisture on $\mathrm{CH}_{4}$ emissions, temperature and soil moisture affected $\mathrm{CO}_{2}$ efflux in different ways at different vegetation communities. Increasing soil temperature was only correlated to increasing $\mathrm{CO}_{2}$ emissions at the wettest sites (fen tussock, fen hollow and sedge hollow) although in all cases, the NEE model was improved by the inclusion of a exponential temperature relationship. Although the $\mathrm{CO}_{2}$ fluxes at the driest sites were not clearly related to soil temperature, near surface $\mathrm{CO}_{2}$ concentrations were positively correlated with soil temperatures at shallow depths at all three of these sites (heath, shrub and sedge tussock). It is possible that variations in measured $\mathrm{CO}_{2}$ effluxes, a combination of both above and belowground respiration were less linked to temperature than belowground $\mathrm{CO}_{2}$ production, which would include a relatively greater influence of microbial decomposition processes versus autotrophic respiration.

Increasing soil moisture increased $\mathrm{CO}_{2}$ emissions only at the dry shrub site while it decreased emissions at the two hollow sites and surprisingly, also at the dry heath site with no relationships to emissions at the two tussock sites. Aside from the heath site, these results suggest an optimum water content below which emissions of $\mathrm{CO}_{2}$ are reduced due to moisture limitations to the microbial communities and potentially to the vegetation itself (shrub site) while above this optimal water content, emissions of $\mathrm{CO}_{2}$ are reduced as oxygen limitations reduce aerobic respiration processes. The unexpected 
results with the heath site and the relatively inconsistent influences of temperature and related variations in thaw depth on $\mathrm{CO}_{2}$ emissions may have occurred in part due to the difficulty in isolating the effects of covarying weather variables where in 2008 , soil moisture and water table levels increased at the end of the growing season as temperature decreased.

Two micrometerological towers have been measuring NEE at Daring Lake, N.W.T, one situated in an upland area and the other located at a fen site. The eddy covariance method allows for continuous ecosystem scale measurements of NEE without disturbing the ecosystem. Measurements of $\mathrm{CO}_{2}$ and $\mathrm{CH}_{4}$ fluxes at the small plot scale using chamber techniques and measurements of subsurface concentrations with subsurface samplers within the fetch of the towers provide further understanding of component processes of this larger scale carbon exchange. Chamber measurements enabled identification of environmental variables which control variations in the carbon exchange rates among the vegetation communities while subsurface concentration measurements aided in determining controls on production, transport and $\mathrm{CH}_{4}$ oxidation through the soil profiles. However, limitations to chamber and subsurface sampler techniques include site alteration, temporally discontinuous measurements, and area representativeness. The combination of both plot and ecosystem scale techniques are complementary and enhance examination of carbon cycling dynamics among the main vegetation communities in this arctic landscape. 
Although our study examined the correlation between various environmental variables and $\mathrm{CO}_{2}$ and $\mathrm{CH}_{4}$ fluxes and concentrations within the landscape, not all controls were investigated. Examining the seasonal nutrient dynamics and availability, the contributions of non-vascular moss to carbon exchange and vascular plant control on both deep oxygen supply and gas transport across the tundra-atmosphere boundary would further our knowledge on carbon cycling dynamics within these vegetation communities. To better quantify the carbon balance in this low arctic landscape rich in peatlands, dissolved and particulate organic and inorganic carbon in these ecosystems must be quantified. Additionally as this research was undertaken in a particularly wet year, future research during dry years will add to our understanding of how hydrology affects interannual variability in $\mathrm{CO}_{2}$ and $\mathrm{CH}_{4}$ exchange in this low arctic landscape. Modelling studies using $\mathrm{CO}_{2}$ and $\mathrm{CH}_{4}$ fluxes and subsurface concentrations to predict depthdependent $\mathrm{CO}_{2}$ and $\mathrm{CH}_{4}$ production and oxidation would also enhance our understanding of controls on production in vegetation communities studied.

Arctic terrestrial ecosystems have a great potential to effect global climate as they store large amounts of carbon, which if exposed to decomposition could increase the emission of $\mathrm{CO}_{2}$ and $\mathrm{CH}_{4}$ to the atmosphere, having a positive feedback on global warming. As the tundra landscape is highly heterogeneous, quantification of current $\mathrm{CO}_{2}$ and $\mathrm{CH}_{4}$ exchange rates and enhanced understanding of controls on carbon dynamics on a great variety of arctic ecosystems is of utmost importance. This study along with others examining $\mathrm{CO}_{2}$ and $\mathrm{CH}_{4}$ fluxes in arctic tundra around the world are contributing to a growing body of work illustrating that these cold regions are not only large stores of soil 
carbon but are characterized by highly dynamic biogeochemical cycles sensitive to subtle variations in a variety of abiotic and biotic influences. By virtue of the vast areas covered by tundra, accurate predictions of future global carbon cycling and climate change will depend on our understanding of these processes in arctic tundra. 


\section{References}

ACIA (2004) Impacts of a Warming Arctic: Arctic Climate Impact Assessment. Cambridge University Press, Cambridge.

Bartlett KB, Harriss RC (1993) Review and assessment of methane emission from wetlands. Chemosphere, 26, 61-320.

Beer J, Blodau C (2007) Transport and thermodynamics constrain belowground carbon turnover in a northern peatland. Geochimica et Cosmochimica Acta, 71, 2989-3002.

Bekele A, Kellman L, Beltrami $\mathrm{H}$ (2007) Soil Profile $\mathrm{CO}_{2}$ concentrations in forested and clear cut sites in Nova Scotia, Canada. Forest Ecology and Management, 242, 587-597.

Billings SA, Richterb DD, Yarie J (2000) Sensitivity of soil methane fluxes to reduced precipitation in boreal forest soils. Soil Biology \& Biochemistry, 32, 1431-1441.

Blodau C (2002) Carbon cycling in peatlands: a review of processes and controls. Environmental Reviews 10,111-134.

Chasar LS, Chanton JP, Glaser PH, Siegel DI (2000) Methane concentration and stable isotope distribution as evidence of rhizospheric processes: comparison of a fen and bog in the glacial Lake Agassiz peatland complex. Annals of Botany, 86, 655-663.

Christensen TR (1993) Methane emission from arctic tundra. Biogeochemistry, 21, 117139.

Christensen TR, Michelsen A, Jonasson S, Schmidt IK (1997) Carbon dioxide and methane exchange of a subarctic heath in response to climate change related environmental manipulations. OIKOS, 79, 34-44.

Christensen TR, Friborg T, Sommerkorn M, Kaplan J, Illeris L, Soegaard H, Nordstroem $\mathrm{C}$, Jonasson $\mathrm{S}$ (2000) Trace gas exchange in a high-arctic valley, 1, Variations in $\mathrm{CO}_{2}$ and $\mathrm{CH}_{4}$ flux between tundra vegetation types. Global Biogeochemical Cycles, 14, 701-713.

Coles JRP, Yavitt JB (2004) Linking belowground carbon allocation to anaerobic CH4 and $\mathrm{CO} 2$ production in a forested peatland, New York state. Geomicrobiology Journal, 21, 445-455.

Corradi C, Kolle O, Walter K, Zimov SA, Schulze ED (2005) Carbon dioxide and methane exchange of a north-east Siberian tussock tundra. Global Change Biology, 11, 1910-1925. 
Crill PM (1991) Seasonal patterns of methane uptake and carbon dioxide release by a temperate woodland soil. Global Biogeochemical Cycles, 5, 319-334.

Davidson EA, Janssens IA (2006) Temperature sensitivity of soil carbon decomposition and feedbacks to climate change. Nature, 440, 165-173.

Dinsmore KJ, Skiba UM, Billett MF, Rees RM (2009) Effect of water table on greenhouse gas emissions from peatland mesocosms. Plant Soil, 318, 229-242.

Dredge LA, Kerr DE, Wolfe SA (1999) Surficial materials and related ground ice conditions, Slave Province, N.W.T., Canada. Canadian Journal of Earth Science, 36, 1227-1238.

Dutta K, Schuur EAG, Neff JC, Aimov SA (2006) Potential carbon release from permafrost soils of Northeastern Siberia. Global Change Biology, 12, 2336-2351.

Elberling B (2003) Seasonal trends of soil $\mathrm{CO}_{2}$ dynamics in a soil subject to freezing. Journal of Hydrology, 276,159-175.

Elberling B (2007) Annual soil $\mathrm{CO}_{2}$ effluxes in the High Arctic: The role of snow thickness and vegetation type. Soil Biology \& Biochemistry, 39, 646-654.

Elberling B, Jakobsen BH, Berg P, Søndergaard J, Sigsgaard C (2004) Influence of vegetation, temperature, and water content on soil carbon distribution and mineralization in four High Arctic soils. Arctic, Antarctic, and Alpine Research, 36, 528-538.

Environment Canada (2005) Ecozones of Canada: Southern Arctic Ecozone. http://www.ec.gc.ca/soer-ree/English/Vignettes/Terrestrial/sa/default.cfm

Fechner-Levy EJ, Hemond HF (1996) Trapped methane volume and potential effects on methane ebullition in a northern peatland. Limnology and Oceanography, 41, 1375-1383.

Flessa H, Rodionov AJ, Guggenberger G, Fuchs H, Magdon P, Shibistova O, Zrazhevskaya G, Mikheyeva N, Kasansky OA, Blodau C (2008) Landscape controls of $\mathrm{CH} 4$ fluxes in a catchment of the forest tundra ecotone in northern Siberia. Global Change Biology, 14, 2040-2056.

Frensel P \& Karofeld E (2000) $\mathrm{CH}_{4}$ emission from a hollow-ridge complex in a raised bog: The role of $\mathrm{CH}_{4}$ production and oxidation. Biogeochemistry, 51, 91-112.

Frolking S, Roulet N, Fuglestvedt J (2006) How northern peatlands influence the Earth's radiative budget: Sustained methane emission versus sustained carbon sequestration. Journal of Geophysical Research, 111, G01008, doi:10.1029/2005JG000091. 
Goldberg SD, Knorr $\mathrm{KH}$ Gebauer $\mathrm{G}$ (2008) $\mathrm{N}_{2} \mathrm{O}$ concentration and isotope signature along profiles provide deeper insight into the fate of $\mathrm{N}_{2} \mathrm{O}$ in soils. Isotopes in Environmental and Health Studies, 44, 377-391.

Griffis TJ, Black TA, Gaumont-Guay D, Drewitt GB, Nesic Z, Barr AG, Morgenstern K, Kljun N (2004) Seasonal variation at partitioning of ecosystem respiration in a southern boreal aspen forest. Agricultural and Forest Meteorology 125, 207-223.

Groendahl L, Friborg T, Soegaard H (2007) Temperature and snow-melt controls on interannual variability in carbon exchange in the high Arctic. Theoretical and Applied Climatology, 88, 111-125.

Hanson RS, Hanson TE (1996) Methanotrophic bacteria. Microbiological Reviews, 60, 439-471.

Harding RJ, Gryning SE, Halldin S, Lloyd CR (2001) Progress in understanding of land surface/atmosphere exchanges at high latitudes. Theoretical and Applied Climatology, 70, 5-18.

Hargreaves KJ, Fowler D, Pitcairn CER, Aurela M (2001) Annual methane emission from Finnish mires estimated from eddy covariance campaign measurements. Theoretical and Applied Climatology, 70, 203-213.

Heyer J, Berger U, Kuzin IL, Yakovlev ON (2002) Methane emissions from different ecosystem structures of the subarctic tundra in Western Siberia during midsummer and during the thawing period. Tellus, 54, 231-249.

Hirsch A I, Trumbore SE, Goulden ML (2003) Direct measurement of the deep soil respiration accompanying seasonal thawing of a boreal forest soil. Journal of Geophysical Research, 107, 8221, doi:10.1029/2001JD000921.

Hobbie SE (1996) Temperature and plant species control over litter decomposition in Alaskan tundra. Ecological Monographs, 66, 503-522.

Hobbie SE Schimel JP, Trumbore SE, Randerson JR (2000) Controls over carbon storage and turnover in high-latitude soils. Global Change Biology, 6, 196-210.

Intergovernmental Panel on Climate Change, IPCC (2007) Climate Change 2007, Synthesis Report, Contribution of Working Groups I, II and III to the Fourth Assessment. Report of the Intergovenmental Panel on Climate Change (Core Writing Team; Pachauri RK, Reisinger A (eds)). IPCC, Geneva, Switzerland.

Jacinthe PA, Groffman PM (2001) Silicone rubber sampler to measure dissolved gases in saturated soils and waters. Soil Biology and Biochemistry, 33, 907-912. 
Jassal RS, Black TA, Drewitt GB, Novak MD, Gaumont-Guay D, Nesic Z (2004) Model of the production and transport of $\mathrm{CO}_{2}$ in soil: predicting soil $\mathrm{CO}_{2}$ concentrations and $\mathrm{CO}_{2}$ efflux from a forest floor. Agricultural and Forest Meteorology, 124, 219-236.

Joabsson A, Christensen TR (2001) Methane emissions from wetlands and their relationship with vascular plants: an Arctic example. Global Change Biology, 7, 919932.

Jobbágy EG, Jackson RB (2000) The vertical distribution of soil organic carbon and its relation to climate and vegetation. Ecological Applications, 10, 423-436.

Jonasson S, Chapin III FS, Shaver GR (2001) Biogeochemistry in the Arctic: patterns, processes and controls. In: Global Biogeochemical Cycles in the Climate System (eds Schulze ED, Harrison SP, Heimann M, Holland EA, Lloyd JJ, Prentice IC, Schimel D), pp. 139-150. Academic Press, New York.

Jones MH, Fahnestock JT, Walker DA, Walker MD, Welker JM (1998) Carbon dioxide fluxes in moist and dry arctic tundra during the snow-free season: responses to increases in summer temperature and winter snow accumulation. Arctic Alpine Research, 30, 373380.

Kammann C, Grünhage L, Jäger $\mathrm{HJ}$ (2001) A new sampling technique to monitor concentrations of $\mathrm{CH} 4, \mathrm{~N} 2 \mathrm{O}$ and $\mathrm{CO} 2$ in air at well-defined depths in soils with varied water potential. European Journal of Soil Science, 52, 297-303.

Kellner E, Waddington JM, Price JS (2005), Dynamics of biogenic gas bubbles in peat: Potential effects on water storage and peat deformation. Water Resources Research, 41, W08417, doi:10.1029/2004WR003732.

Kemper WD, Rosenau RC (1986) Aggregate stability and size distribution. In: Methods of Soil Analysis (Part I) (ed. Klute A), pp. 425-442. American Society of Agronomy, Madison, WI.

King JA, Smith KA (1987) Gaseous diffusion through peat. Journal of Soil Science, 38, 173-177.

Kim SH, Reddy VR, Baker JT, Gitz DC, Timlin D.J (2004) Quantification of photosynthetically active radiation inside sunlight growth chambers. Agricultural and Forest Meteorology. 126, 117-127.

King JY, Reeburgh WS, Regli SK (1998) Methane emission and transport by arctic sedges in Alaska: Results of a vegetation removal experiment. Journal of Geophysical Research, 103, 29083-29092. 
Knorr $\mathrm{KH}$, Oosterwoud M, Blodau C (2008) Experimental drought alters rates of soil respiration and methanogenesis but not carbon exchange in soil of a temperate fen. Soil Biology \& Biochemisyry, 40, 1781-1791.

Knorr KH, Lischeid G, Blodau C (in press) Dynamics of redox processes in a minerotrophic fen exposed to a water table manipulation. Geoderma.

Kutzbach L, Wagner D, Pfeiffer EM (2004) Effect of microrelief and vegetation on methane emission from wet polygonal tundra, Lena Delta, Northern Siberia.

Biogeochemistry, 69, 341-362

Kutzbach L, Wille C, Pfeiffer EM (2007) The exchange of carbon dioxide between wet arctic tundra and the atmosphere at the Lena River Delta, Northern Siberia. Biogeosciences, 4, 869-890.

Kutzbach L, Schneider J, Sachs T, Giebels M, Nyka"nen H, Shurpali NJ, Martikainen PJ, Alm J, Wilmking M (2007) $\mathrm{CO}_{2}$ flux determination by closed-chamber methods can be seriously biased by inappropriate application of linear regression. Biogeosciences, 4,1005-1025.

Lafleur PM, Humphreys ER (2008) Spring warming and carbon dioxide exchange over low Arctic tundra in central Canada. Global Change Biology, 14, 740-756.

Lafleur PM (2009) Connecting atmosphere and wetland: trace gas exchange. Geography Compass, 3/2, 560-585.

Lai DYF (2009) Methane dynamics in northern peatlands: A review. Pedosphere, 19, $409-421$.

Laing CG, Shreeve TG, Pearce DME (2008) Methane bubbles in surface peat cores: in situ Measurements. Global Change Biology, 14, 916-924.

Liblik LK, Moore TR, Bubier JL, Robinson SD (1997) Methane emissions from wetlands in the zone of discontinuous permafrost: Fort Simpson, Northwest Territories, Canada. Global Biogeochemical Cycles, 11, 485-494.

Liebner S, Wagner D (2007) Abundance, distribution and potential activity of methane oxidizing bacteria in permafrost soils from the Lena Delta, Siberia. Environmental Microbiology, 9, 107-117.

Lloyd CR (2001) The measurement and modelling of the carbon dioxide exchange at a high arctic site in Svalbard. Global Change Biology, 7, 405-426. 
Luo Y, Zhuo $X$ (2006) Soil Respiration and the Environment. Academic Press, Burlington, MA, and San Diego, CA, USA.

MacDonald JA, Fowler D, Hargreaves KJ, Skiba U, Leith ID, Murray MB (1998) Methane emission rates from a northern wetland: response to temperature, water table and transport. Atmospheric Environment, 32, 3219-3227.

Mastepanov M, Sigsgaard C, Dlugokencky EJ, Houweling S, Strom L, Tamstorf MP, Christensen TR (2008) Large tundra methane burst during onset of freezing. Nature, 456, $628-631$.

Maxwell B (1997) Recent climate patterns in the Arctic. In: Global Change and Arctic Terrestrial Ecosystems (eds Oechel WC,Callaghan T, Gilmanov T, Holten J, Maxwell B, Molau U, Sveinbjornsson B), pp. 21-46. Springer, New York.

Maxwel B (1992) Arctic climate: potential for change under global warming. In: Arctic Ecosystems in a Changing Climate: An Ecophysiological Perspective (eds Chapin FS, Jefferies RL, Reynolds JF, Shaver GR, Svoboda J), pp. 11-34. Academic Press, San Diego.

Mayo JM, Despain DG, van Zinderen Bakker Jr. EM (1973) $\mathrm{CO}_{2}$ assimilation by Dryas integrifolia on Devon Island, Northwest Territories. Canadian Journal of Botany, 51, 581-588.

McClain JET, Kepler TB, and Ahmann DM (2002) Belowground factors mediating changes in methane consumption in a forest soil under elevated $\mathrm{CO}_{2}$. Global Biogeochem. Cycles, 16, 1050, doi:10.1029/2001GB001439.

McFadden JP, Eugster W, Chapin III FS (2003) A regional study of the controls on water vapor and $\mathrm{CO}_{2}$ exchange in arctic tundra. Ecology, 84, 2762-2776.

Metje M, Frenzel P (2007) Methanogenesis and methanogenic pathways in a peat from subarctic permafrost. Environmental Microbiology, 9, 954-964.

Nordstroem C, Soegaard H, Christensen TR, Friborg T, Hansen BU (2001) Seasonal carbon dioxide balance and respiration of a high-arctic fen ecosystem in NE-Greenland. Theoretical and Applied Climatology, 70, 149-166.

Nykänen H, Alm J, Silvola J, Tolonen K, Martikainen PJ (1998) Methane fluxes on boreal peatlands of different fertility and the effect of long-term experimental lowering of the water table on flux rates. Global Biogeochemical Cycles, 12, 53-69.

Oberbauer SF, Tweedie CE, Welker JM, Fahnestock JT, Henry GHR, Webber PJ, Hollister RD, Walker MD, Kuchy A, Elmore E, Starr G (2007) Tundra $\mathrm{CO}_{2}$ fluxes in 
response to experimental warming across latitudinal and moisture gradients Ecological Monographs, 77, 221-238.

Oechel WC, Vourlitis GL, Hastings SJ, Zulueta RC, Hinzman L, Kane D (2000) Acclimation of ecosystem $\mathrm{CO}_{2}$ exchange in the Alaskan arctic in response to decadal climate warming. Nature, 406, 978-981.

Overpeck JK, Hughen D, Hardy R, Bradley R, Case M, Douglas B, Finney K, Gajewski G, Jacoby A, Jennings et al., (1997) Arctic environmental changes of the last four centuries. Science, 278, 1251-1256.

Popp TJ, Chanton JP, Whiting GJ, Grant N (1999), Methane stable isotope distribution at a Carex fen in north central Alberta. Global Biogeochemical Cycles, 13, 1063-1077.

Post WM, Emanuel WR, Zinke PJ, Strangenberger, AG (1982) Soil carbon pools and world life zones. Nature 298, 156-159.

Reeburgh WS, Whalen SC (1992) High latitude ecosystems as $\mathrm{CH}_{4}$ sources. Ecological Bulletins, 42, 62-70.

Rennermalm AK, Soegaard H, Nordstroem C (2005) Interannual variability in carbon dioxide exchange from a High Arctic fen estimated by measurements and modeling. Arctic, Antarctic, and Alpine Research, 37, 545-556.

Rinne J, Riutta T, Pihlatatie M, Aurela M, Haapanala S, Tuovinen JP, Tuittila ES, Vesala $T$ (2007) Annual cycle of methane emission from a boreal fen measured by the eddy covariance technique. Tellus, 59B, 449-457.

Risk D, Kellman L, Beltrami H (2002) Carbon dioxide in soil profiles: production and temperature dependence. Geophysical Research Letters, 29, 11-1-11-4.

Risk D, Kellman L, Beltrami H (2008) A new method for in situ soil gas diffusivity measurement and applications in the monitoring of subsurface $\mathrm{CO}_{2}$ production. Journal of Geophysical Research, 113, G02018, doi:10.1029/2007JG000445.

Rosenberry DO, Glaser PH, Siegel DI (2006) The hydrology of northern peatlands as affected by biogenic gas: current developments and research needs. Hydrological Processes, 20, 3601-3610.

Rodionow A, Flessa H, Kazansky O, Guggenberger G (2006) Organic matter composition and potential trace gas production of permafrost soils in the forest tundra in northern Siberia. Geoderma, 135, 49-62. 
Roulet N, Reeburgh W, Alperin M, Desjardin R, Galchenko V, Glooschenko W, Lassiter R, Lassey K, Moore T, Schiff H, Svensson BH, Wahlen M, Zarvarzin G (1992) Highlatitude ecosystems: sources and sinks of trace gases. Ecological Bulletins, 42, 86-97.

Sachs T, Wille C, Boike J, Kutzback L (2008) Environmental controls on ecosystemscale $\mathrm{CH}_{4}$ emission from polygonal tundra in the Lena River Delta, Siberia. Journal of Geophysical Research, 113, G00A03, doi:10.1029/2007JG000505.

Sander R (1999) Compilation of Henry's Law Constants for Inorganic and Organic Species of Potential Importance in Environmental Chemistry (Version 3). MaxPlanck Institute of Chemistry, Mainz, Germany. http://www.henrys-law.org.

Schimel JP (1995) Plant transport and methane production as controls on methane flux from arctic wet meadow tundra. Biogeochemistry, 28, 183-200.

Schuur EAG, Bockheim J, Canadell JG, Euskirchen E, Field CB, Goryachkin SV, Hagemann S, Kuhry P, Lafleur PM, Lee H, Mazhitova G, Nelson FE, Rinke A, Romanovsky VE, Shiklomanov N, Tarnocai C, Venevsky S, Vogel JG, Zimov SA (2008) Vulnerability of permafrost carbon to climate change: implications for the global carbon cycle. BioScience, 58, 701-714.

Sjögersten S, Wookey PA (2002) Spatio-temporal variability and environmental controls of methane fluxes at the forest-tundra ecotone in the Fennoscandian mountains.

Global Change Biology, 8, 885-894.

Smemo KA, Yavitt JB (2006) A multi-year perspective on methane cycling in a shallowpeat fen in central New York State, USA. Wetlands, 26, 20-29.

Soegaard H, Nordstroem C, Friborg T, Hansen BU, Christensen TR, Bay C (2000) Trace gas exchange in a high-arctic valley 3 . Integrating and scaling $\mathrm{CO}_{2}$ fluxes from the canopy to landscape using flux data, footprint modeling, and remote sensing. Global Biogeochemical Cycles, 14, 725-744.

Sommerkorn M (2008) Micro-topographic patterns unravel controls of soil water and temperature on soil respiration in three Siberian tundra systems. Soil Biology \& Biochemistry, 40, 1792-1802.

Sjögersten S, van der Wal R, Woodin SJ (2006) Small-scale hydrological variation determines landscape CO2 fluxes in the high Arctic. Biogeochemistry, 80, 205-216.

Strack M, Waddington JM (2008) Spatiotemporal variability in peatland subsurface methane dynamics. Journal of Geophysical Research, 113, G02010, doi:10.1029/2007JG000472. 
Sturm, M., C. Racine and K. Tape (2001) Increasing shrub abundance in the Arctic. Nature, 411, 546-547.

Sundh I, Nilsson M, Granberg G, Svensson BH (1994) Depth distribution of microbial production and oxidation of methane in northern boreal peatlands. Microbial Ecology, 27, 253-265.

Sundh I, Mikkelä C, Nilsson M, Svensson BH (1995) Potential aerobic methane oxidation in a Sphagnum-dominated peatland - controlling factors and relation to methane emission. Soil Biology \& Biochemistry, 27, 829-837.

Tarnocai C (2004) Classification of cryosols in Canada. In: Cyrosols: Permafrostaffected Soils (ed. Kimble JM), pp. 599-610. Springer, Berlin, Germany.

Tokida T, Miyazaki T, Mizoguchi M, Nagata O, Takakai F, Kagemoto A, Hatano R (2007) Falling atmospheric pressure as a trigger for methane ebullition from peatland. Global Biogeochemical Cycles, 21, GB2003.

Torn MS, Chapin FS III (1993) Environmental and biotic controls over methane flux from arctic tundra. Chemosphere, 26, 357-368.

van der Molen MK, van Huissteden J, Parmentier FJW, Petrescu1 AMR, Dolman1 AJ, Maximov TC, Kononov AV, Karsanaev SV, Suzdalov DA (2007) The growing season greenhouse gas balance of a continental tundra site in the Indigirka lowlands, NE Siberia. Biogeosciences, 4, 985-1003.

Wagner D, Kobabe S, Pfeiffer EM, Hubberten HW (2003) Microbial controls on methane fluxes from a polygonal tundra of the Lena Delta, Siberia. Permafrost and Periglacial Processes, 14, 173-185.

Watson A, Stephen KD, Nedwell DB, Arah JRM (1997) Oxidation of methane in peat: kinetics of $\mathrm{CH}_{4}$ and $\mathrm{O}_{2}$ removal and the role of plant roots. Soil Biology and Biochemistry, 29, 1257-1267.

Welker JM, Fahnestock JT, Henry GHR, O'Dea KW, Chimner RA (2004) $\mathrm{CO}_{2}$ exchange in three Canadian High Arctic ecosystems: response to long-term experimental warming. Global Change Biology, 10, 1981-1995.

Weller G, Chapin FS, Everett KR, Hobbie JE, Kane D, Oechel WC, Ping CL, Reeburgh WS, Walker D, Walsh J (1995) The Arctic Flux Study: A regional view of trace gas release. Journal of Biogeography, 22, 365-374.

Whalen SC, Reeburgh WS (1990) Consumption of atmospheric methane by tundra soils. Nature, 346, 160-162. 
Wille C, Kutzbach L, Sachs T, Wagner D, Pfeiffer EM (2008) Methane emission from Siberian arctic polygonal tundra: Eddy covariance measurements and modeling. Global Change Biology, 14, 1-14.

Yavitt JB, Seidmann-Zager M (2006) Methanogenic conditions in northern peat soils. Geomicrobiology Journal, 23,119-127.

Zimov SA, Davidov SP, Voropaev Y, Prosiannikov SF, Semiletov IP, Chapin MC, Chapin, FS (1996) Siberian $\mathrm{CO}_{2}$ efflux in winter as a $\mathrm{CO}_{2}$ source and cause of seasonality in atmospheric $\mathrm{CO}$. Climatic Change, 33, 111-120. 


\section{Appendix}

The following are examples of the subsurface $\mathrm{CO}_{2}$ and $\mathrm{CH}_{4}$ concentration conversion equations from ppmv to $\mu \mathrm{mol} \mathrm{L}^{-1}$ used in Chapter 3 . The ratio of water to air filled pore space is used to determine the contribution of $\mathrm{CO}_{2}$ and $\mathrm{CH}_{4}$ from the gas and dissolved phase. Example values are used from the fen hollow 1, 0-10 cm sampling internal on day of year 207.

\section{Variables and Constants:}

$\mathrm{CH}_{4}$ concentration: $137 \mathrm{ppmv}$

$\mathrm{CO}_{2}$ concentration: $2336 \mathrm{ppmv}$

VWC: $71 \%$

Porosity: 0.94

Average soil temperature (t): $10.9^{\circ} \mathrm{C}$

Atmospheric pressure: $96770 \mathrm{~Pa}$

Average $\mathrm{pH}$ of fen: 4.7

Acid dissociation constant of carbonic acid (pKa): 6.4

$K_{H}^{\ominus}$ : Henry coefficient at standard conditions, $0.00129\left(\mathrm{CH}_{4}\right) \& 0.0339\left(\mathrm{CO}_{2}\right)\left(\mathrm{mol} \mathrm{L}^{-1}\right.$ $\mathrm{atm}^{-1}$ )

$\mathrm{T}$ : Temperature in Kelvin

$T^{\ominus}:$ Standard temperature $(298.15 \mathrm{~K})$

To determine the ratio of water to air filled pore space:

$$
\begin{aligned}
& \theta \text { water }=\frac{\text { Vliquid }}{\text { Vtotal }} \\
& \theta \text { water }=\text { Porosity } \frac{\text { Vliquid }}{\text { Vpores }} \\
& \frac{\text { Vliquid }}{\text { Vpores }}=\frac{\theta \text { water }}{\text { Porosity }} \\
& \frac{\text { Vliquid }}{\text { Vpores }}=\frac{0.71}{0.94}=0.76
\end{aligned}
$$

Therefore $76 \%$ of pore space is water and the remaining $24 \%$ is air. 155 
To determine the Henry coefficients for $\mathrm{CH}_{4}$ and $\mathrm{CO}_{2}$ :

$$
\begin{gathered}
K_{H}=K^{\ominus} \exp \frac{d \ln K_{H}}{d \frac{1}{T}}\left(\frac{1}{T}-\frac{1}{T^{\ominus}}\right) \\
K_{H\left(C H_{4}\right)}=\exp \left(-1600\left(\frac{1}{298.15}-\frac{1}{t+273.15}\right)\right)-\operatorname{Ln}(0.00129) \\
K_{H\left(C H_{4}\right)}=\exp \left(-1600\left(\frac{1}{298.15}-\frac{1}{10.9+273.15}\right)\right)-\operatorname{Ln}(0.00129) \\
K_{H\left(C H_{4}\right)}=0.00168 \mathrm{~mol} \mathrm{~L}^{-1} \mathrm{~atm}^{-1} \\
K_{H\left(C O_{2}\right)}=\exp \left(-2400\left(\frac{1}{298.15}-\frac{1}{t+273.15}\right)\right)-\operatorname{Ln}(0.0339) \\
K_{H\left(\mathrm{CO}_{2}\right)}=\exp \left(-2400\left(\frac{1}{298.15}-\frac{1}{10.9+273.15}\right)\right)-\operatorname{Ln}(0.0339) \\
K_{H\left(C O_{2}\right)}=0.05055 \mathrm{~mol} \mathrm{~L}^{-1} \mathrm{~atm}^{-1}
\end{gathered}
$$

Conversion of $\mathrm{CH}_{4}$ and $\mathrm{CO}_{2}$ concentration in ppmv to $\mu \mathrm{mol} \mathrm{L} \mathrm{L}^{-1}$ using the ideal gas law:

$$
\begin{gathered}
\mathrm{CH}_{4}\left(\mu \mathrm{mol} \mathrm{L}^{-1}\right)=\frac{\mathrm{CH}_{4}(\mathrm{ppmv}) \mathrm{P}}{\mathrm{RT}} / 1000 \\
\mathrm{CH}_{4}\left(\mu \mathrm{mol} \mathrm{L}^{-1}\right)=\frac{137(96770)}{8.314(273.15+10.9)} / 1000 \\
\mathrm{CH}_{4}\left(\mu \mathrm{mol} \mathrm{L}^{-1}\right)=5.6 \\
\mathrm{CO}_{2}\left(\mu \mathrm{mol} \mathrm{L}^{-1}\right)=\frac{\mathrm{CO}_{2}(\mathrm{ppmv}) \mathrm{P}}{\mathrm{RT}} / 1000 \\
\mathrm{CO}_{2}\left(\mu \mathrm{mol} \mathrm{L}^{-1}\right)=\frac{2336(96770)}{8.314(273.15+10.9)} / 1000
\end{gathered}
$$




$$
\mathrm{CO}_{2}\left(\mu \mathrm{mol} \mathrm{L}{ }^{-1}\right)=95.7
$$

Conversion of $\mathrm{CH}_{4}$ and $\mathrm{CO}_{2}$ concentration in ppmv to dissolved $\mathrm{CO}_{2}$ and $\mathrm{CH}^{4}\left(\mu \mathrm{mol} \mathrm{L} \mathrm{L}^{-1}\right)$ :

$$
\begin{gathered}
{\left[\mathrm{CH}_{4}\right]_{\text {Dissolved }}=K_{\mathrm{H}\left(\mathrm{CH}_{4}\right)}\left[\mathrm{CH}_{4}\right]_{\text {Gas-phase }}} \\
{\left[\mathrm{CH}_{4}\right]_{\text {Dissolved }}=0.00168(137)} \\
{\left[\mathrm{CH}_{4}\right]_{\text {Dissolved }}=0.23 \mu \mathrm{mol} \mathrm{L}^{-1}} \\
{\left[\mathrm{CO}_{2}\right]_{\text {Dissolved }}=K_{\mathrm{H}\left(\mathrm{CO}_{2}\right)}\left[\mathrm{CO}_{2}\right]_{\text {Gas }- \text { phase }}+K_{\mathrm{H}\left(\mathrm{CO}_{2}\right)}\left[\mathrm{CO}_{2}\right]_{\text {Gas-phase }}\left(10^{-p K a} / 10^{-p H}\right)} \\
{\left[\mathrm{CO}_{2}\right]_{\text {Dissolved }}=0.05055(2336)+0.05055(2336)\left(10^{-6.4} / 10^{-4.7}\right)} \\
{\left[\mathrm{CO}_{2}\right]_{\text {Dissolved }}=120.43 \mu \mathrm{mol} \mathrm{L}^{-1}}
\end{gathered}
$$

Determination of $\mathrm{CO}_{2}$ and $\mathrm{CH}_{4}$ concentration using the ratio of water to air filled pore Space:

Total $\mathrm{CH}_{4}$ concentration $=\frac{\text { Vliquid }}{\text { Vpores }} \times\left[\mathrm{CH}_{4}\right]_{\text {Dissolved }}+\frac{\text { Vair }}{\text { Vpores }} \times\left[\mathrm{CH}_{4}\right]_{\text {Gas }-P \text { hase }}$ Total $\mathrm{CH}_{4}$ concentration $=0.76 \times 2.3 \mu \mathrm{mol} \mathrm{L}{ }^{-1}+0.24 \times 5.6 \mu \mathrm{mol} \mathrm{L}^{-1}$

Total $\mathrm{CH}_{4}$ concentration $=1.5 \mu \mathrm{mol} \mathrm{L}{ }^{-1}$

Total $\mathrm{CO}_{2}$ concentration $=\frac{\text { Vliquid }}{\text { Vpores }} \times\left[\mathrm{CO}_{2}\right]_{\text {Dissolved }}+\frac{\text { Vair }}{\text { Vpores }} \times\left[\mathrm{CO}_{2}\right]_{\text {Gas }-P \text { hase }}$ Total $\mathrm{CO}_{2}$ concentration $=0.76 \times 120.43 \mu \mathrm{mol} \mathrm{L}^{-1}+0.24 \times 95.7 \mu \mathrm{mol} \mathrm{L}{ }^{-1}$ Total $\mathrm{CO}_{2}$ concentration $=114.5 \mu \mathrm{mol} \mathrm{L}^{-1}$ 